\title{
Análise de avaliação de desempenho em hospital público
}

\author{
Elizabeth Perazzolo
}

Tese apresentada ao Programa de Pós-Graduação em Saúde Pública da Faculdade de Saúde Pública da Universidade de São Paulo para obtenção do título de Doutor em Saúde Pública.

Área de Concentração: Serviço de Saúde Pública

Orientadora: Profa. Dra. Vitória Kedy Cornetta

São Paulo

2008 
É expressamente proibida a comercialização deste documento, tanto na sua forma impressa como eletrônica. Sua reprodução total ou parcial é permitida exclusivamente para fins acadêmicos e científicos, desde que na reprodução figure a identificação do autor, título, instituição e ano da tese/dissertação. 


\section{DEDICATÓRIA}

A Deus, por ter permitido e iluminado a minha caminhada.

Em memória dos meus pais Domingos Perazzolo e Rosária M. Perazzolo (Guida) que, pelos seus ensinamentos e valores, sempre me incentivaram na busca incansável por novos conhecimentos.

À minha irmã Maria Inês, pelo estímulo, apoio, compreensão e paciência. 


\section{AGRADECIMENTOS}

À Profa. Dra. Vitória Kedy Cornetta, pela amizade, incentivo, respeito, orientação segura ao longo destes anos e pela confiança em mim depositada.

À Maria José Amaral de Barros Ritzmann, Cristiane Santiago e Márcia Camargo, amigas e parceiras no trabalho, pela paciência, compreensão, apoio e incentivo.

À Amélia Q. Hashimoto pelo incentivo, apoio e revisão gramatical.

À Gisele Nazar pelo estímulo e ajuda nas traduções.

Aos meus colegas e amigos do Instituto do Coração do Hospital das Clínicas da Faculdade de Medicina - Universidade de São Paulo (InCor-HC.FMUSP) que direta ou indiretamente, com compreensão, amizade e colaboração, ajudaram a viabilizar este trabalho.

Ao Serviço de Gestão do Fator Humano do InCor-HC.FMUSP, por meio de Adelmo Fachim e das suas lideranças e, em especial, à Vilma Nepomuceno, que despertaram em mim forte curiosidade em percorrer caminhos repletos de surpresas no mundo da gestão de pessoas por competências.

À Faculdade de Saúde Pública da Universidade de São Paulo, pelos conhecimentos transmitidos, por meio de seu competente corpo de docentes, agregando valor ao meu aprimoramento profissional.

Ao Núcleo de Planejamento e Gestão da Superintendência do HC.FMUSP, por meio de sua equipe, pela realização da metodologia do Prêmio Nacional da Gestão em Saúde (PNGS), que despertou em mim o interesse para o tema da pesquisa. 


\section{Resumo}

Perazzolo E. Análise de avaliação de desempenho em hospital público [tese de doutorado]. São Paulo: Faculdade de Saúde Pública da USP; 2007.

A avaliação de desempenho é uma das ações essenciais à gestão de pessoas, pois dela surgem conseqüências importantes para a motivação, aprendizagem, comprometimento e progressão funcional. Avaliar desempenho constitui um desafio aos líderes. Objetivo - É conhecer e analisar, segundo as lideranças de hospital público, o processo de avaliação de desempenho. Método - Estudo exploratório realizado com amostra intencional de líderes das áreas assistencial, de apoio e administrativa de uma instituição pública, com experiências em processos de avaliação, nos papéis de avaliado e avaliador. Foram estruturados três grupos focais, variando de 8 a 11 componentes cada. Os encontros, gravados, com duração aproximada de duas horas, foram conduzidos pela pesquisadora, utilizando guia de discussão. Resultados - Na análise de conteúdo, as manifestações foram agrupadas em cinco categorias: expectativas dos líderes; sentimentos manifestados; atributos avaliados; atitudes dos líderes evidenciadas; contribuições ao processo. Conclusões Avaliação de desempenho é imprescindível nas organizações e deve estar alinhada às diretrizes institucionais e políticas de gestão de pessoas; deve ser transparente, objetiva e ética diminuindo subjetividade; gerar planos de desenvolvimento sendo processo educativo e não punitivo. A capacitação técnica e preparo emocional dos avaliadores favorecem o feedback e a aprendizagem, respeitando a individualidade do avaliado. Instrumento de avaliação precisa ter estrutura padronizada inserindo competências técnicas e comportamentais, além de perguntas abertas para o avaliador. Fundamental é mudar a terminologia de avaliação de desempenho para verificação das competências. Considerações finais - Os líderes expressam sentimentos positivos com a avaliação de desempenho quando há justiça, seriedade e sigilo no processo gerando desenvolvimento; manifestam frustrações em situações 
contrárias que resultam na desmotivação. Foram destacados, para além dos objetivos do estudo, os atributos da liderança a serem avaliados.

Descritores: Gestão de pessoas; Avaliação de desempenho; Competência. Liderança; Hospital. 


\begin{abstract}
Perazzolo E. Análise de avaliação de desempenho em hospital público/The Assessment of Performance in a Public Hospital [thesis]. São Paulo (BR): Faculdade de Saúde Pública da Universidade de São Paulo; 2007.
\end{abstract}

The assessment of performance is one of the most essential procedures for the management of people because it causes important consequences in terms of motivation, learning, commitment and functional development. Assessing the performance is a challenge to the leaders. Objective - To know and analyze the process of the assessment of performance, according to the public hospital leaderships. Method - Exploratory study with an intentional sample of leaders in assistential, supporting and administrative areas of a public institution with experience in the process of evaluation, and in the roles of evaluated and evaluator. Three focus groups were formed, ranging from 8 to 11 members each. The meetings were recorded with the duration of approximately two hours and were led by the investigator of this study, by using a guide of discussion. Results - Based on the analysis of contents, the manifestations were grouped into five categories: leaders expectations, demonstrated feelings, enhanced attitudes, assessed attributes and contributions to the process. Conclusion - The assessment of performance is absolutely necessary for the organizations and must be aligned with the institutional orientations and management of people policie; it has to be transparent, ethical and objective, with little subjectiveness; it also has to generate plans for the development, since it is an educating, not punishing process. The technical ability and emotional preparation of the evaluators contribute to the feedback and learning process, preserving the individual aspects of the evaluated ones. The evaluation tool needs to be standardized with behavioral and technical competencies, besides the open questions for the evaluator. It is essential to change the assessment of performance terminology to check the competencies. Final considerations - The leaders demonstrate positive feelings in relation to the assessment of performance when it is fair, serious and sigilous in the process generating development; they show frustation 
in situations contrary to the cases causing unmotivation. Besides the objectives of this study, it was emphasized the attributes of the leadership to be assessed.

Keywords: People management; Assessment of performance; Competence; Leadership; Hospital. 


\section{Í N D I C E}

1 INTRODUÇÃO 11

2 JUSTIFICATIVA 19

3 OBJETIVO GERAL 24

4 OBJETIVOS ESPECÍFICOS 24

5 REVISÃO DA LITERATURA 25

5.1 MODELO DE GESTÃO DE PESSOAS POR COMPETÊNCIAS 25

5.2 AVALIAÇÃO DE DESEMPENHO COM FOCO EM COMPETÊNCIAS 36

5.3 ARTE DE SER LÍDER 42

5.4 GESTÃO HOSPITALAR 48

6 MÉTODO DE PESQUISA 55

6.1 TIPO DE PESQUISA

6.2 LOCAL DA PESQUISA 58

6.3 UNIVERSO OU POPULAÇÃO 60

$\begin{array}{ll}6.4 \text { AMOSTRA } & 60\end{array}$

6.5 SUJEITOS DA PESQUISA 61

6.6 COLETA DE DADOS 62

6.7 ANÁLISE DOS DADOS 65

6.8 PROCEDIMENTOS ÉTICOS 66

7 RESULTADOS E DISCUSSÃO 68

$7.11^{\text {a }}$ PARTE - CARACTERIZAÇÃO DOS LÍDERES 68

$7.22^{\mathrm{a}}$ PARTE - ANÁLISE DO PROCESSO DE AVALIAÇÃO DE DESEMPENHO 76

8 CONCLUSÕES 116

9 CONSIDERAÇÕES FINAIS 117

10 REFERÊNCIAS 121

11 BIBLIOGRAFIA CONSULTADA 126

ANEXOS

Anexo 1 - Carta de convocação dos líderes 127

Anexo 2 - Guia de discussão para grupos de líderes sobre a avaliação de 128 desempenho

Anexo 3 - Caracterização do sujeito da pesquisa 129

Anexo 4 - Termo de consentimento das lideranças entrevistadas 130 


\section{Lista de Quadros}

Quadro 1 - Vantagens para a organização e para as pessoas sobre a 26 utilização do conceito de competências.

Quadro 2 - Pesquisa qualitativa versus pesquisa quantitativa.

Quadro 3 - Vantagens e desvantagens da técnica de grupo focal.

Quadro 4 - Expectativas dos líderes sobre o processo de avaliação.

Quadro 5 - Manifestações de satisfação e de insatisfação dos líderes sobre o processo de avaliação.

Quadro 6 - Fatores que agradaram e desagradaram os líderes no processo de avaliação (sentimentos).

Quadro 7 - Principais atributos (competências) da força de trabalho a serem avaliados.

Quadro 8 - Atributos (competências) importantes de um líder a 103 serem avaliados.

Quadro 9 - Como avaliar e o motivo da avaliação (atitudes).

Quadro 10 - Formulário de avaliação e forma de apresentação dos resultados (contribuições). 


\section{Lista de Gráficos}

Gráfico 1 - Caracterização das lideranças quanto à faixa etária.

Gráfico 2 - Caracterização das lideranças quanto ao sexo.

Gráfico 3 - Caracterização das lideranças quanto ao tempo na instituição.

Gráfico 4 - Caracterização das lideranças quanto à profissão.

Gráfico 5 - Caracterização das lideranças quanto ao nome do cargo.

Gráfico 6 - Caracterização das lideranças quanto ao tempo no cargo.

Gráfico 7 - Caracterização das lideranças quanto à jornada de trabalho.

Gráfico 8 - Caracterização das lideranças quanto ao número de 75 funcionários sob sua responsabilidade. 


\section{INTRODUÇÃO}

A passagem de uma sociedade industrial para uma sociedade da informação; o valor dado ao capital humano, ou seja, à educação e ao desenvolvimento de competências das pessoas como força dominante da economia; o investimento em altas tecnologias; o foco na economia mundial; o estilo descentralizador e participativo; o compromisso profissional e a comunicação lateral intensa são mudanças observadas pelo Homem, que proliferam a uma velocidade cada vez mais crescente. Como destaca CRAWFORD (1994) “... novos conhecimentos levam às novas tecnologias, as quais, por sua vez, levam as mudanças econômicas; que, conseqüentemente, geram mudanças sociais e políticas, as quais, em última instância, criam um novo paradigma ou visão de mundo” (p.16).

Na era da competitividade, para o dinâmico e complexo universo de recursos humanos, entra em cena o conceito modelo de gestão de pessoas, que vem ganhando legitimidade. Para DUTRA et al. (2001), esse modelo “... deve ser compreendido como o conjunto de políticas, práticas, padrões atitudinais, ações e instrumentos empregados por uma empresa para interferir no comportamento humano e direcioná-lo no ambiente de trabalho” (p.20).

Essas iniciativas são provenientes de diferentes instâncias da organização, tais como: os programas de qualidade, os processos de elaboração do planejamento estratégico e as intervenções diretamente dirigidas para orientar o comportamento organizacional (sistemas de remuneração, de gestão de carreiras, de avaliação de desempenho, de captação e demissão de pessoas).

O termo modelo, para esse autor, funciona como "peneira" e "molde" propiciando a seleção de idéias e ações, bem como estruturando uma maneira coerente de pensar sobre a realidade para a tomada de decisão. 
No $1^{\circ}$ Encontro Internacional de Gestão de Competências em Qualidade de Vida no Trabalho, em 1998, DUTRA menciona que as grandes mudanças, vividas pelas empresas e pelo ambiente cultural da sociedade ocidental moderna, ocasionam uma transformação significativa na gestão de pessoas. Tais mudanças estão relacionadas às estruturas e às formas de organização do trabalho mais flexíveis, aos processos de trabalho ágeis e focados no mercado, à velocidade exigida para entrar e sair de mercados locais e globais e ao alto grau de competitividade. Esse cenário requer pessoas comprometidas e envolvidas com o negócio e com postura autônoma e empreendedora; que estejam atualizadas com as tendências do mercado e com o campo de atuação, tanto em termos nacionais como internacionais; e que procurem articulação e negociação no trabalho, formando um time em processo contínuo de aprimoramento e aperfeiçoamento.

Assim, a empresa para sobreviver é importante superar desafios e, para ter sucesso, é preciso competir. PRAHALAD (1997) caracteriza o panorama competitivo das organizações nos seguintes subconjuntos:

1. "Do cômodo ao competitivo", ser um inovador; transformar habilidades gerenciais antigas e aprender com o novo.

2. “Do local ao global”, abrindo novos caminhos para as empresas já estabelecidas.

3. “Do 'gostar de mim' para o 'gostar de quem?'”, diz respeito a complexa competição da empresa com seus concorrentes. O fato está em não apenas competir com o conhecido, mas está relacionado em competir com estranhos.

4. "Das fronteiras setoriais nítidas às indefinidas”, surgindo em cena a combinação de funcionalidade nos novos negócios, gerando incertezas.

5. "Da estabilidade à volatilidade”, onde as empresas experimentam novos produtos e serviços.

6. "Dos intermediários ao acesso direto”, reduzindo as camadas existentes entre o cliente e o fornecedor.

7. “Da integração vertical aos especialistas”, propiciando melhor relação e negociação com os concorrentes, criando, assim, uma nova dimensão e diferencial competitivo. 
8. "De uma herança intelectual única à múltipla”, ocasionada pela convergência tecnológica, o que exige um novo perfil das lideranças nas organizações.

Todo esse cenário impõe um modelo de gestão de pessoas onde a liderança enfrenta diversos desafios como: significativas alterações na estrutura organizacional da empresa; novas formas de organização eficiente e eficaz do trabalho; avaliação de desempenho e o desenvolvimento de competências da força de trabalho e do próprio líder que estejam alinhadas às estratégias organizacionais.

O líder, ciente de suas competências, conquista sua legitimidade junto aos seus liderados na medida em que exista um clima de confiança e respeito mútuo no ambiente de trabalho, bem como um grande esforço para seu aprendizado contínuo em lidar com as pessoas, gerando seu comprometimento com as práticas relativas ao capital intelectual.

Para PERAZZOLO (2000), o líder, desenvolvendo e aperfeiçoando suas competências humanas e técnico-gerenciais de forma continuada, busca o sucesso na administração do seu negócio. Ele passa a ser o elemento principal, modificando sua maneira de pensar e agir, como também sendo o próprio agente transformador do seu meio e grupo.

Essa consciência e dinamismo da liderança podem contribuir para o sucesso da organização que busca, cada vez mais, servir melhor o cliente, gerar maiores resultados, obter o comprometimento das pessoas e ser inovadora. Para WARDMAN (1996), "Uma estratégia competitiva de sucesso atual pode não ser mais válida no futuro. As empresas precisam estar atentas para isso, aumentando continuamente sua capacidade de aprender e inovar” (p.11).

É fato de que o mundo se movimenta muito rápido. A diversidade e a mudança estão se tornando universais. A tecnologia avança a cada dia. A tomada de decisões está cada vez mais complexa. Conflitos que ultrapassam fronteiras (culturais, 
econômicas, religiosas, étnicas e ideológicas) são muito comuns. Dessa forma, hoje, liderar sabendo lidar com os conflitos passou a ser imprescindível (GERZON, 2006).

O líder não pode atuar como ditador e nem como gestores comuns (administradores). A liderança eficaz é aquela que:

1. Assume o compromisso em considerar, integralmente, os aspectos racional e emocional que envolvem o conflito;

2. Transcende limites e desfaz estereótipos, auxiliando as partes a trabalhar em conjunto para fortalecer o todo;

3. Levanta questões estabelecendo diálogo entre as partes;

4. Desenvolve parcerias e alianças;

5. Lida com as diferenças existentes na organização, possuindo a habilidade de transformar diferença em oportunidade (inovação).

Essas competências da liderança podem ser refletidas nas instituições hospitalares e sua aplicabilidade um desafio ao líder, no dia-a-dia.

O hospital para atingir elevados níveis de eficiência e eficácia precisa ser concebido como uma empresa e assumir, com a coletividade, um importante papel na produção de serviços (GONÇALVES e ACHÉ, 1999).

CASTELAR et al. (1995) analisam o hospital, examinando elementos que caracterizam as empresas. Quanto ao aspecto humano e de produção, o hospital é um grupo de pessoas direcionado à produção de serviços (assistência prestada aos pacientes); quanto ao aspecto patrimonial, ele é constituído de informações que integram o próprio balanço (crédito, dívidas, dentre outras) e, também, de dados como reputação, marca, imagem, renome e competência técnica e, quanto ao aspecto da troca de serviços prestados à saúde, o hospital pode receber diretamente de seus pacientes ou indiretamente por um sistema de seguro social, permitindo que as receitas ultrapassem as despesas. 
Não se trata de transformar os hospitais em empresas, mas, também, não se deve esquecer que o hospital é um negócio e, como todo negócio, tem que ter lucro para sobreviver no mercado.

O maior patrimônio de um hospital é seu capital intelectual, especificamente sua força de trabalho. Em alguns hospitais públicos e privados existe a preocupação em manter o pessoal capacitado e qualificado para o desempenho das funções. Apesar disso, vale ressaltar que nos hospitais privados quando acontece alguma intercorrência o profissional é sumariamente desligado, o que não ocorre nos hospitais públicos em virtude da lentidão da máquina administrativa.

O fundamento que norteia os modelos de gestão nas instituições hospitalares públicas é a tensão existente entre a restrição de recursos versus as necessidades de investimentos. Isso acaba gerando reformas administrativas importantes para garantir a modernização hospitalar e a racionalização dos serviços, com melhores desempenhos e menores custos, sendo ofertados aos pacientes do Sistema Único de Saúde (SUS) e àqueles vinculados à Saúde Suplementar.

O paciente do SUS ou da Saúde Suplementar não tem a condição de estimar a qualidade técnica da intervenção médico-hospitalar. O que ele percebe é a maneira como é tratado em termos da atenção dispensada por toda equipe, dos esclarecimentos dados sobre os procedimentos que fazem parte da sua assistência, da alimentação equilibrada, da limpeza diária, dentre outros serviços prestados, fazendo-o ser fiel àquela determinada instituição hospitalar.

O importante é ressaltar que os serviços prestados apenas têm valor quando existem a competência dos profissionais e a presença de uma liderança comprometida com a satisfação desse paciente, com a eficiência dos processos de trabalho, com a educação continuada dos funcionários e com os resultados da organização. 
O líder faz a ligação entre a organização hospitalar e as pessoas que nela trabalham. O sucesso dessa articulação depende de seu estilo específico, mais participativo e descentralizador ou mais autocrático e centralizador.

Dentre os Fundamentos do PNGS - Prêmio Nacional da Gestão em Saúde 2004, que sustentam os Critérios de Avaliação da Gestão das Organizações, divulgados pela FPNQ (2003-2004), pode-se destacar a Liderança e Constância de Propósitos. De acordo com tal fundamento, “... a força propulsora da excelência organizacional está baseada na capacidade e no comprometimento da alta direção em desenvolver um sistema de gestão eficaz, que estimule as pessoas a um propósito comum e duradouro, considerando os valores, as diretrizes e as estratégias da organização e comprometendo-os com resultados” (p.9).

Além disso, salienta que:

“ ... a ação da alta direção e dos demais líderes deve conduzir ao equilíbrio no atendimento das necessidades de todas as partes interessadas, promovendo o desenvolvimento da organização de forma harmônica, sustentada e virtuosa. A participação pessoal, ativa e continuada da alta direção cria clareza e unidade de propósito na organização e nas pessoas direcionando-as para a busca da excelência. Por meio do seu comportamento ético, das suas habilidades de planejamento, comunicação e análise crítica de desempenho e da sua capacidade de estimular a motivação nas pessoas, a alta direção serve de exemplo para todos, desenvolvendo um sistema de liderança em todos os níveis, capaz de manter o engajamento das pessoas na causa da organização” (p.9).

Os hospitais, em suas diversas especialidades, necessitam de líderes competentes para que possam responder às exigências do ambiente externo, caracterizado por desafios políticos, econômicos, sociais e tecnológicos e às do ambiente interno com ênfase nos pontos fortes e oportunidades de melhoria da organização, apresentando a eficiência e eficácia dos processos de trabalho e estabelecendo políticas coerentes em gestão de pessoas. Tais competências das lideranças precisam estar claras e definidas na organização, servindo de parâmetros para uma avaliação crítica do desempenho profissional. 
O líder tem mais poder para alcançar as metas organizacionais e estabelecer uma relação de trabalho eficaz com sua equipe quando há a descrição de competências, a avaliação sistemática do desempenho e o plano de desenvolvimento de tais competências.

A maioria das pessoas precisa da ajuda do líder para visualizar e compreender os pontos fortes e os aspectos de melhoria do desempenho. Elas necessitam saber em quais competências estão se saindo extremamente bem e quais precisam desenvolver e mudar.

A avaliação deve considerar as necessidades, as expectativas e, até mesmo, a personalidade do avaliado, onde se procura enfatizar os aspectos positivos e mostrar os pontos que necessitam ser melhorados ou alterados, além de motivar o colaborador a melhorar o seu desempenho e gerar orgulho.

Toda avaliação, atrelada a uma política institucional, deve alavancar o potencial das pessoas para o alto desempenho, sem destruir a visão de futuro das mesmas. A avaliação é um processo complexo, abrangente, subjetivo, discutível e polêmico que pode ser uma prática nas instituições públicas e privadas.

Para o líder ser bem sucedido, ele precisa ter feedback sobre a sua performance. Da mesma forma, os membros de sua equipe necessitam saber quando e como melhorar suas competências.

Apesar do processo de avaliação gerar uma aprendizagem tanto para o avaliado quanto para o avaliador, ele pode causar ansiedade, frustrações, sentimento de insegurança e desmotivação para ambas as partes, demonstrando o cuidado do líder na utilização desse instrumento de gestão.

Este estudo não enfatizará as características dos hospitais públicos e privados para a implementação do instrumento de avaliação de desempenho. A instituição pública foi eleita por suas reformas administrativas, que são fundamentais à sua sobrevivência e, 
também, pela própria experiência da pesquisadora nos processos de gestão de pessoas em hospital público.

Portanto, é importante conhecer a avaliação de desempenho, segundo as lideranças que atuam em um hospital público, revelando os aspectos essenciais para a eficiência dessa ferramenta de gestão. 


\section{JUSTIFICATIVA}

O cenário mundial caracteriza-se por profundas mudanças repletas de turbulências e tensões nas esferas políticas, tecnológicas, econômicas e sociais. Segundo DUTRA (2005), “...ser líder nesse contexto significa legitimar-se pela sua capacidade de conciliar as expectativas da organização com as de seus liderados e de oferecer referências em um ambiente de grande volatilidade” (p.8).

A década de 90 foi considerada a "década do líder". No começo existia a busca por um herói que mudaria a vida das pessoas e estabeleceria uma nova direção para tirá-las das situações difíceis. Hoje, as organizações buscam líderes visionários, ou seja, pessoas que por características de personalidade trazem transformações relevantes para a empresa.

A liderança é um fenômeno social, um processo de influência interpessoal exercida numa dada situação e conduzida por meio de um processo de comunicação, visando os resultados efetivos para as pessoas, para as organizações, para a comunidade e sociedade. De acordo com DUTRA (2005), “... a liderança não surge de modo instantâneo. Ela deve ser cultivada ao longo do tempo” (p.9).

Dessa forma, é fundamental considerar e trabalhar a cultura organizacional, o planejamento estratégico, a gestão dos processos e as dimensões que caracterizam a gestão de pessoas (motivação, liderança, comunicação, dentre outras), para estimular o desenvolvimento de potenciais líderes e reforçar o comportamento necessário ao reconhecimento profissional da força de trabalho.

Um ambiente favorável para desenvolver as competências das lideranças é o do respeito ao indivíduo, à organização e à sociedade, além do posicionamento ético alicerçado em valores. 
O líder centralizador e autoritário tem seu espaço na cultura de muitas empresas. No entanto, ele caminha em contramão às necessidades das organizações modernas e das pessoas. Um ambiente voltado ao empreendedorismo, à iniciativa e à criatividade exige uma liderança mais participativa e democrática. Uma postura autoritária da liderança pode gerar resultados a curto prazo, mas no médio e no longo prazos agregará pouco valor para a empresa e para as pessoas.

YUKL (2001) destaca os esforços dos cientistas sociais em descobrirem os traços, as habilidades, os comportamentos, a origem do poder, bem como as situações que determinam como o líder é capaz de influenciar seus seguidores e alcançar os objetivos. A eficácia de uma liderança é evidenciada pelo comportamento do líder, seja nos processos de trabalho seja na gestão de pessoas, caracterizando-se pelas ações de:

1. Planejar: estabelecendo objetivos, prioridades, estratégias, recursos e responsabilidades;

2. Clarificar: explicando as metas a serem alcançadas, as prioridades, as regras e o trabalho/atividades;

3. Monitorar: envolvendo a avaliação dos trabalhos realizados e o desempenho dos colaboradores;

4. Apoiar: demonstrando consideração pelas necessidades e sentimentos das pessoas;

5. Desenvolver o profissional no trabalho, facilitando a adaptação no ambiente e ampliando as possibilidades de carreira na organização ou no mercado externo;

6. Reconhecer o desempenho e a contribuição efetiva na instituição.

Os líderes que agregam valor são, também, aqueles que entendem a importância da complementaridade das pessoas num grupo, apoiando e incentivando o desenvolvimento de cada uma delas. São conscientes de que as competências necessárias para executar a liderança, de maneira eficaz, podem ser aprendidas, avaliadas e desenvolvidas continuamente. 
Liderar é encorajar as pessoas à união e ao compromisso para a realização de um trabalho conjunto, com objetivo comum, desenvolvendo o senso de equipe, criando expectativas realizáveis, acompanhando os resultados, reconhecendo e recompensando os esforços.

De acordo com os princípios da qualidade, o processo de gestão exige postura de uma liderança mais participativa e descentralizada em cada unidade e em cada degrau da organização. Os líderes analisam criticamente a performance organizacional e tomam ações, consolidando o controle e o aprendizado. A instituição deve saber avaliar o desempenho dos líderes e desenvolvê-los, pois, estes são os principais responsáveis pela obtenção dos resultados que asseguram a satisfação de todas as partes interessadas e a perpetuidade da empresa.

Hoje, os hospitais devem estar muito além do que apenas prestarem assistência à saúde. Os hospitais públicos e privados têm sido alvos freqüentes de dois aspectos importantes: a qualidade pelo serviço prestado e a busca por resultados que são obtidos por pessoas comprometidas, qualificadas e motivadas.

Esse é o maior desafio dos gerentes-líderes, pois, de um lado é fundamental que seus valores, crenças e motivação tragam para o ambiente organizacional o verdadeiro sentido da palavra comprometimento e, por outro lado, devem estar sempre atentos aos aspectos que envolvem a valorização e o reconhecimento das pessoas. O líder de sucesso precisa possuir competências gerenciais e técnicas, bem como inúmeras características pessoais, intelectuais, emocionais e físicas para vencer os desafios.

Os hospitais são, provavelmente, as instituições mais carentes no que diz respeito à descrição das competências e a eficiência do processo de avaliação de desempenho. Tal carência pode ser atribuída a vários fatores, seja pelo fato de não ser conhecido e nem disseminado na organização o conceito de competência; seja pela existência de uma nomenclatura antiga de cargos voltados às atribuições e requisitos básicos, requerendo do líder ações mais imediatas; seja, enfim, pelo não monitoramento do processo de desenvolvimento e avaliação. 
Como exemplo dessa carência, cita-se um trabalho de avaliação (FPNQ-PNGS, ciclo 2003-2004) desenvolvido em um complexo hospitalar público, sobre os critérios de avaliação da gestão em saúde, onde não foram contemplados os itens descrição das competências e avaliação dos líderes e da força de trabalho, sendo que tais aspectos são relevantes no processo rumo à excelência organizacional.

Por outro lado, esta pesquisadora, que trabalha há mais de 20 anos em hospital público, observou que o assunto competência profissional é prematuro e o processo de avaliação de desempenho traz poucos resultados práticos.

Nesse contexto, vale ressaltar que:

1. A competência sustenta-se em um conjunto de conhecimentos, habilidades e atitudes da pessoa, incluindo o seu diferencial na entrega do serviço prestado e no grau de complexidade de sua atuação.

2. O processo de avaliação procura destacar os pontos fortes da pessoa e os aspectos de melhoria do seu desempenho, permitindo a estruturação de um plano de ação que resulte na prestação de serviços com qualidade. Além dessas informações objetivas do desempenho, o momento da avaliação é permeado por expectativas e sentimentos do avaliador e do avaliado podendo trazer distorções em seu resultado.

Outro aspecto importante é que neste estudo, a maioria dos autores referendados é consultor de empresas, administrador ou professor na área de gestão de pessoas, trazendo experiências no desenvolvimento de lideranças e na implantação de projetos de recursos humanos como, por exemplo: avaliação, gestão por competência, diagnóstico comportamental, desenvolvimento humano e organizacional, dentre outros. Portanto, na área da saúde são escassos os trabalhos vivenciados no segmento gestão de pessoas. 
Assim, considerando os assuntos relacionados à liderança, à competência e à avaliação inseridos no contexto hospitalar público, foi necessário realizar estudos com líderes onde pudessem expressar seus sentimentos, suas críticas, suas opiniões e expectativas diante do processo de avaliação e suas contribuições para a eficiência do processo, sendo o escopo desta pesquisa. 


\section{OBJETIVO GERAL}

Conhecer, segundo a ótica das lideranças do hospital público, o processo de avaliação de desempenho.

\section{OBJETIVOS ESPECÍFICOS}

- Descrever e analisar as expectativas, os sentimentos e as atitudes das lideranças frente ao processo de avaliação.

- Identificar e analisar as contribuições das lideranças para a eficiência do processo de avaliação de desempenho. 


\section{REVISÃO DA LITERATURA}

\subsection{MODELO DE GESTÃO DE PESSOAS POR COMPETÊNCIAS}

De acordo com DUTRA et al. (2001), o processo de gestão de pessoas sofreu grandes transformações ao longo dos últimos vinte anos, podendo citar:

1. Alteração de um perfil obediente e disciplinado para um perfil mais autônomo e empreendedor exigido pelas organizações;

2. Deslocamento do foco de gestão (passiva) de pessoas, por meio do controle, para a idéia voltada ao desenvolvimento mútuo (empresapessoa);

3. Maior participação das pessoas no sucesso da organização.

Mas, o mecanismo de gerir pessoas, adotado pela maior parte das empresas, muitas vezes não atende às demandas da realidade. Alguns gerentes estão preocupados em direcionar suas forças para um mercado mais competitivo. Isso traz como conseqüência a utilização de métodos tradicionais de gestão, mais adequados ao dia-a-dia, gerando um forte descontentamento na dinâmica de administrar indivíduos.

De acordo com Versiani e Bastos, citados por PERAZZOLO (2000),

“A experiência tem mostrado que muitos dos gerentes enxergam a necessidade de mudar, embora, muitas vezes, não entendem nem percebem que os mecanismos utilizados para mudar não promovem a mudança necessária. Muitos têm gasto mais energia com a inteligência competitiva e menos com o marketing inteligente, deixando de captar as necessidades do cliente, ficando assim presos à competição predatória dos mercados tradicionais. Novas oportunidades exigem olhar o mundo de uma maneira nova, por uma ótica nova, reciclando os modelos mentais das pessoas" (p.26).

Nas organizações mais avançadas, portanto, os líderes, das diversas áreas, se tornam gestores de pessoas ganhando autonomia nas decisões e nas ações a respeito de seus colaboradores. Estão comprometidos com o processo de 
preparar e desenvolver os indivíduos. Nesse contexto, ROSSO (2003) define o Gestor de Pessoas como “... todo e qualquer líder que conduz uma equipe de trabalho. (...) hoje em dia, as lideranças em uma instituição são (ou deveriam ser) a continuação dos braços da área de Recursos Humanos” (p.19).

A gestão por competências, quando aplicada e internalizada na organização, pode ser útil ao cumprir três tarefas estratégicas: a) articular as ações de recursos humanos à estratégia organizacional e, portanto, aos resultados do negócio; b) integrar os processos principais de gestão, tornando-os mais coerentes e consolidados; c) ligar o desempenho das pessoas às estratégias da organização.

Assim, a utilização do conceito de competência, inserido em um modelo de gestão de pessoas alinhado com as expectativas da organização e das pessoas, apresenta uma série de vantagens para ambos os lados (Quadro 1).

Quadro 1 - Vantagens para a organização e para as pessoas sobre a utilização do conceito de competências

\begin{tabular}{|l|l|lrl|}
\hline \multicolumn{2}{|c|}{ PARA A ORGANIZAÇÃo } & \multicolumn{3}{|c|}{ PARA AS PESSOAS } \\
\hline Simplicidade, flexibilidade e transparência. & $\begin{array}{l}\text { Horizontes profissionais claros com } \\
\text { critérios de acesso definidos. }\end{array}$ \\
\hline $\begin{array}{l}\text { Equilíbrio entre remuneração e valor } \\
\text { agregado. }\end{array}$ & $\begin{array}{l}\text { Remuneração compatível com a } \\
\text { complexidade das atribuições e das } \\
\text { responsabilidades e com o mercado. }\end{array}$ \\
\hline $\begin{array}{l}\text { Direcionamento e otimização dos } \\
\text { investimentos no desenvolvimento } \\
\text { profissional. }\end{array}$ & $\begin{array}{l}\text { Estímulo ao autodesenvolvimento e à } \\
\text { abrangência da atuação. }\end{array}$ & \\
\hline $\begin{array}{l}\text { Capacidade de atração, retenção e } \\
\text { potencialização de talentos. } \\
\text { Adaptação às mudanças de estrutura, } \\
\text { organização do trabalho e tecnologia. }\end{array}$ & $\begin{array}{l}\text { Condições claras e objetivas para a } \\
\text { mobilidade profissional entre as carreiras. }\end{array}$ \\
\hline
\end{tabular}

Fonte: adaptado de DUTRA, J. S. et al. (2001). Gestão por competências: um modelo avançado para o gerenciamento de pessoas. p. 42. 
Para acompanhar as exigências das organizações e alcançar os resultados, o líder precisa ser competente e desempenhar com sucesso o trabalho alicerçado em metas e objetivos. Esse é considerado um aspecto crítico dentro das empresas, sobretudo nas instituições hospitalares.

Na Era da Competência, as empresas precisam de indivíduos que sejam mais do que bons profissionais e que tenham um conjunto de competências necessárias para garantir o sucesso.

A competência é inseparável da ação. Não se reduz a um estado ou conhecimento, a um saber ou habilidade. Consiste na capacidade da pessoa gerar resultados e atender os objetivos pessoais e/ou organizacionais.

É fundamental ressaltar que a organização e as pessoas possuem um conjunto próprio de competências. No caso da organização, a construção da competência nasce do seu processo de desenvolvimento, estabelecendo vantagens competitivas dentro do cenário no qual está inserida. Com relação às pessoas, a construção da competência é caracterizada pela integração de três eixos: a pessoa com sua biografia e socialização, sua formação e sua situação profissional. Tais competências podem ou não serem aproveitadas pela organização.

De qualquer maneira, organização e pessoas, lado a lado, propiciam um processo contínuo de troca de competências. Pode-se dizer que existe uma relação íntima, ou melhor, uma influência entre as competências organizacionais e as individuais.

Mas, o que significa competência?

A palavra competência é utilizada de maneira diferente pelos especialistas em recursos humanos e estrategistas de negócios. No Novo Dicionário da Língua Portuguesa, FERREIRA (1975) define competência como sendo 
"... a qualidade de quem é capaz de apreciar e resolver certo assunto, fazer determinada coisa; capacidade, habilidade, aptidão, idoneidade” (p.354).

Precisa-se entender que habilidade compõe a competência, assim como o conhecimento e as atitudes. Logo, não tem sentido afirmar habilidade como sinônimo de competência, pois ela é um dos aspectos fundamentais para uma pessoa ser competente.

Já COOPERS e LYBRAND (1997) apresentam a definição do especialista Scott B. Parry que define competência como: “... um agrupamento de conhecimentos, habilidades e atitudes correlacionados, que afeta parte considerável da atividade de alguém, que se relaciona com o desempenho, que pode ser medido segundo padrões preestabelecidos, e que pode ser melhorado por meio de treinamento e desenvolvimento” (p.126). Destacam que competência é o conhecimento aplicado e orientado para melhorar o desempenho do indivíduo, do grupo e da organização; deve ter relação com as atividades principais e não com as atividades de suporte ou apoio; e que deve ser medida de acordo com padrões.

Existe uma tendência em definir competência mencionando o popular conceito CHA, ou seja, um conjunto de conhecimentos (saber), habilidades (saber fazer) e atitudes (querer fazer) de uma pessoa. Nesse contexto, LEME (2006) separa o CHA em dois grupos:

“Competências Técnicas: É tudo o que o profissional precisa ter para desempenhar seu papel, e são expressas pelo C e pelo H do CHA, o 'saber' e o 'Saber Fazer'.

Competências Comportamentais: São o diferencial competitivo de cada profissional e têm impacto em seus resultados. Aqui, são expressas pelo A do CHA, o ‘Querer Fazer’ ’' (p.3). 
A Gestão de Pessoas com foco em competências não pode ficar apenas no conceito do CHA (conhecimentos, habilidades e atitudes), apesar dele por si só ser fundamental, mas não é suficiente.

RABAGLIO (2006) escreve que competência é o conjunto de “conhecimentos, habilidades e atitudes que são os diferenciais de cada pessoa e têm impacto em seu desempenho e conseqüentemente nos resultados atingidos” (p.23). Uma pessoa tem bom desempenho quando possui conhecimentos imprescindíveis, habilidades e atitudes essenciais para a eficiência e a eficácia dos seus processos de trabalho.

O ser humano deve ser visto como um ser sistêmico e integrado em suas dimensões racionais e emocionais. É importante compreender o interrelacionamento entre capacidade emocional, intelectual e física. Exemplos:

- Pessoas podem raciocinar de modo errado, caso esteja presente um problema emocional importante;

- Um modo de interpretar o mundo de forma errônea pode levar a presença de sentimentos inadequados, como a desmotivação;

- Um problema de saúde pode afetar a habilidade e, conseqüentemente, o quadro emocional.

Para DUTRA et al. (2001), competência envolve três importantes atributos:

- Capacidade de entrega do serviço pelo colaborador;

- Complexidade dessa entrega caracterizada pela presença de ações com certo grau de dificuldade;

- Espaço ocupacional da pessoa decorrente da complexidade de suas ações na prestação do serviço.

Ainda DUTRA et al. (2001), citando Maria Tereza Fleury, competência é “Saber agir de maneira responsável (...) implica mobilizar, integrar, 
transferir conhecimentos, recursos, habilidades que agreguem valor econômico à organização e valor social ao indivíduo” (p.27).

Assim, o simples fato de uma pessoa possuir determinados conhecimentos, habilidades e atitudes não garantem a sua entrega, ou seja, aquilo que agrega valor para a organização (rentabilidade). Uma pessoa pode ter as qualificações necessárias para um determinado trabalho, mas isso não assegura que a mesma irá entregar o que lhe é demandado.

A competência de uma pessoa precisa ser compreendida por sua capacidade de entrega, agregando valor à instituição, à própria pessoa e ao meio em que vive, gerando resultados de acordo com os objetivos organizacionais. Uma pessoa se desenvolve quando amplia a sua capacidade de entrega do serviço demonstrando sua eficiência e eficácia na realização do trabalho.

Importante é valorizar as pessoas por seus atos e suas realizações e não pela descrição formal de seus cargos. Sabe-se que cargo é um item na folha de pagamento e um registro em carteira enquanto que função representa o que o colaborador deve ser ou fazer em sua organização. Desse modo, a pessoa é o que ela faz de forma eficaz. Olhar as pessoas por sua capacidade de entrega é uma perspectiva adequada para os processos de avaliação, orientação e recompensa em virtude de seu caráter individualizado.

O outro atributo no conceito de competência é a complexidade. Um indivíduo, dentro de um processo específico de desenvolvimento, adquire a capacidade de assumir e de executar atribuições e responsabilidades de maior complexidade.

Para FERNANDES (2004), “O nível de complexidade está relacionado ao grau de abstração exigido para que a decisão tomada seja correta, e pode ser medido a partir do intervalo de tempo entre a tomada de decisão e a possibilidade de avaliação dos resultados dela decorrentes” (p.27). 
Um desafio empresarial consiste, portanto, na determinação dessa complexidade, estabelecendo uma escala de níveis que tem relação consistente com as características da estrutura organizacional e com os aspectos significativos do mercado no qual está inserida. Dois profissionais podem ter uma determinada competência, porém o primeiro é um profissional Júnior que apresentará capacidade direcionada para resolver problemas mais simples (operacionais), enquanto que um diretor vai requerer competência em um nível de complexidade superior.

A Avaliação de Competência Técnica ("saber" e "saber fazer") e Avaliação de Competência Comportamental (“querer fazer”), fazendo parte de um processo de Avaliação de Desempenho por Competências, necessitam medir a "entrega" do serviço prestado pelo colaborador e a “complexidade” da sua função.

Em toda organização é importante a presença de pessoas com competências técnicas e competências comportamentais (atitudinais) que gerem resultados, mas, que, também, contribuam para o crescimento da instituição, que é justamente a entrega de cada um, dentro do padrão de complexidade de cada cargo.

O atributo espaço ocupacional decorre da relação entre complexidade de ações e agregação de valor, ou seja, envolve um conjunto de responsabilidades profissionais assumido pelo indivíduo no desenvolvimento do trabalho, ampliando seus limites na organização. As pessoas mais competentes, em geral, são chamadas a novos desafios e, na medida em que obtêm sucesso, recebem desafios ainda maiores.

Assim, cabe enfatizar a evolução na aplicação do conceito competência. Inicialmente, competência era voltada aos conhecimentos, habilidades e atitudes das pessoas. Por meio do processo evolutivo somente o CHA passou 
a ser insuficiente. Gestão de Pessoas por Competências passa, assim, a buscar resultados organizacionais com competência por meio dos colaboradores, visando manter ou ampliar as vantagens competitivas da empresa.

Entre tantas definições existentes sobre competências, a autora deste estudo adota o conceito de DUTRA et al. (2001) pela inserção dos aspectos de entrega, complexidade e espaço ocupacional na verificação da competência de uma pessoa e não apenas o conjunto de conhecimentos, habilidades e atitudes refletindo, dessa forma, uma nova relação entre trabalho e empresa:

\footnotetext{
“A competência de uma pessoa pode ser compreendida como sua capacidade de entrega. Uma pessoa é competente quando, graças às suas capacidades, entrega e agrega valor ao negócio ou empresa em que atua, a ele próprio e ao meio em que vive. Uma pessoa se desenvolve quando amplia sua capacidade de entrega. Estabelecendo diferentes níveis de complexidade dessa entrega, estamos construindo uma escala para mensurar e orientar o desenvolvimento" (p.46).
}

Ao ser competente, a pessoa passa a assumir mais responsabilidades e atribuições. De certo modo, isso é evidenciado nos níveis hierárquicos da organização e também nos diferentes degraus da remuneração. Em outras palavras: a instituição paga mais porque o colaborador agrega mais valor à empresa, assumindo responsabilidades de maior complexidade; e assume tais atribuições à medida que busca de forma continuada seu desenvolvimento.

Inúmeras empresas procuram identificar e mapear suas competências críticas, procurando categorizá-las de várias formas, como exemplo: em competências essenciais (organizacionais), gerenciais e funcionais (técnicas) de acordo com a cultura da organização.

Cabe esclarecer que as essenciais sustentam a cultura e os valores da organização, garantindo o alinhamento com os pilares estratégicos. COOPERS e LYBRAND (1997) mencionam Prahalad e Hamel que 
"utilizam a expressão competência essencial (core competence) quando tratam das capacidades que levam as empresas à liderança em seu setor" (p.123).

Mais especificamente, para PRAHALAD e HAMEL (1990) são três os aspectos que identificam core competencies na organização: ter potencial acesso para uma ampla variedade de mercado, trazer produtos essenciais (core products) agregando benefícios ao cliente e ser de difícil imitação pelos competidores. Nesse contexto, as competências essenciais mantêm a liderança da empresa no mercado, estabelecendo sua vantagem competitiva.

Os líderes, respeitando a cultura organizacional, precisam compreender os desafios e as oportunidades que a empresa tende a empreender para alcançar os resultados esperados e, a partir daí, definir as competências da força de trabalho e da própria liderança, como também as necessidades de desenvolvimento e aperfeiçoamento, visando impactar o negócio.

De forma sistêmica, o que pode levar o líder ao sucesso é (XAVIER, 2002):

1. Sua competência comportamental que inclui o autoconhecimento, a capacidade de controlar as próprias emoções, motivação e automotivação, empatia e habilidade de relacionamento com as pessoas (equipe, pares, chefes, clientes, fornecedores, parceiros);

2. Sua competência técnica, seus conhecimentos aprofundados e especializados da área de atuação, seus conhecimentos sobre o comportamento do mercado, sua experiência da prática administrativa e do negócio, sua visão da Instituição e seu autodesenvolvimento contínuo;

3. Sua capacidade intelectual direcionada à incorporação constante de novas informações, à criatividade, à busca do saber implícito (intuição), à orientação estratégica para o alcance dos resultados em um mundo de incertezas e ao raciocínio lógico para as análises das variáveis (internas e externas), das relações e dos processos de trabalho; 
4. Seu investimento na saúde e vigor físico/mental, proporcionando maior capacidade de trabalho.

Para a implementação efetiva e assertiva do Modelo de Gestão por Competências é necessário seu alinhamento com as estratégias organizacionais (missão, visão, valores, metas, análise dos ambientes externo e interno).

Segundo TACHIZAWA e SCAICO (1997):

"Se não há uma clara definição do negócio em que a empresa se insere, com certeza não se pode gerenciar efetivamente a organização em seus níveis estratégicos, tático e operacional. Sem a orientação de uma estratégia clara, não se pode ter certeza da adequada alocação de recursos, de gerenciamento dos processos críticos de negócios e de recompensa do desempenho esperado" (p.75).

É fundamental saber dirigir os esforços para aquilo que traz resultados. O responsável por um negócio não pode deixar de ser eficiente porque ser eficiente é desenvolver bem sua obrigação. Ele precisa contribuir para o melhor resultado de toda a empresa, ou seja, necessita ser eficaz, pois, ser eficaz é o que traz o sucesso organizacional. Saber aproveitar as oportunidades e prevenir as ameaças são desafios de todo líder.

A base para a definição de um modelo de competências é constituída por meio do planejamento estratégico. Para ALMEIDA (2003), "Planejamento estratégico é uma técnica administrativa que procura ordenar as idéias das pessoas, de forma que se possa criar uma visão do caminho que se deve seguir (estratégia)” (p.13). Depois de ordenar as idéias, são elaboradas as ações implementando o Plano Estratégico, para que sem desperdício de esforços, a organização caminhe na direção pretendida. Pode-se dizer que constitui em um processo participativo, envolvendo todos os níveis da Instituição.

O Modelo de Gestão por Competências precisa estar relacionado às necessidades e ao foco do negócio e, alinhado aos valores e à missão da 
empresa na medida em que visa selecionar, capacitar e remunerar por competências. O modelo, sendo desenvolvido de forma participativa, auxilia a construir e reforçar os comportamentos que fazem parte da cultura organizacional.

O planejamento estratégico, sendo uma técnica dinâmica, um processo sistemático de análise e de reestruturação, interfere no sistema de competências que sofre também mudanças, na medida em que acompanha as necessidades do negócio, que espelham os atributos considerados críticos para o sucesso organizacional dentro de uma perspectiva de tempo. A mudança por um determinado mercado faz a organização direcionar seus esforços, recursos e comportamentos de sua força de trabalho para o atendimento de novas necessidades.

Vale enfatizar, portanto, que o modelo de competências em uma empresa precisa estar alinhado ao planejamento estratégico, respeitando a dinâmica da cultura organizacional e considerando as exigências do mercado. Essa integração subsidia a tomada de decisão, estabelecendo as competências de hoje e do futuro da força de trabalho, bem como da liderança, gerando resultados que agregam valor ao negócio.

As organizações que têm problemas trabalhistas ou que possuem uma cultura mais autoritária terão certo grau de dificuldade para a implantação de um Sistema de Gestão de Pessoas por Competências, pois apresentam visão limitada não conseguindo alinhar o trabalho com o desenvolvimento pessoal e, também, não percebem que investir em Competência significa aumentar a empregabilidade.

Em linhas gerais, dentre os vários fatores críticos de sucesso para a implantação nas organizações de um modelo de gestão por competência, podem ser destacados:

- Comprometimento da alta direção com visão para resultados;

- Infra-estrutura organizacional; 
- Metodologia clara e consistente;

- Avaliação crítica da performance empresarial por meio de metas e indicadores;

- Políticas coerentes de gestão de pessoas e avaliação de desempenho pautada em competências que será discutida no próximo item.

\subsection{AVALIAÇÃO DE DESEMPENHO COM FOCO EM COMPETÊNCIAS}

A chave do sucesso em Gestão de Pessoas consiste no estabelecimento de um processo de avaliação eficaz.

Toda avaliação é utilizada para:

- Ajustar os objetivos com as metas da organização e da equipe;

- Desenvolver a visão sistêmica da organização;

- Buscar eficácia na comunicação interna;

- Melhorar a performance (desempenho);

- Manter a motivação e o compromisso;

- Analisar o desenvolvimento;

- Identificar necessidades de treinamento;

- Estimular o aperfeiçoamento;

- Comemorar êxitos e aprender com os erros;

- Compreender os desejos de crescimento profissional na empresa;

- Avaliar o potencial e obter o máximo de produtividade de cada colaborador.

Os métodos tradicionais de avaliação de desempenho, em virtude de suas limitações, têm forçado as organizações a buscarem formas inovadoras, criativas, mais participativas, caracterizadas também por nova concepção de auto-avaliação, foco no futuro e na melhoria contínua do desempenho.

O desafio das empresas é desenvolver mecanismos capazes de dirigir os esforços das pessoas para os objetivos e metas que não apenas sirvam à organização, mas, 
sobretudo, que atendam aos interesses (motivos) das pessoas, buscando a integração entre os objetivos institucionais e pessoais.

Nesse contexto, o gestor-líder precisa compreender os fatores direcionados às motivações intrínsecas e extrínsecas do ser humano. De acordo com VANSTEENKISTE et al. (2006), a motivação intrínseca representa o compromisso do indivíduo na atividade por sua própria causa, sem fatores externos, sendo importante base para a aprendizagem e o desenvolvimento. Enquanto que a motivação extrínseca sofre a influência/controle de fatores externos (recompensas, fiscalização, últimos prazos, dentre outros) determinando o comportamento da pessoa.

Assim, quanto mais saudáveis forem o contexto organizacional e as relações interpessoais vinculadas ao conhecimento dos aspectos motivacionais e dos fatores que diminuem a insatisfação, maior é a facilidade para se obter as mudanças nas atitudes esperadas.

Os caminhos da avaliação de desempenho têm sido marcados por dois fatores fundamentais:

- A substituição da estrutura funcional e departamentalizada, pela organização por processos e por equipes;

- A participação dos colaboradores nos resultados, permitindo negociações claras e objetivas entre as partes.

Os benefícios de toda avaliação consistem em:

- Ser um processo facilitador do autoconhecimento, autodesenvolvimento, autocrítica e melhoria contínua;

- Estimular e envolver toda empresa para o alcance dos resultados organizacionais e do desenvolvimento profissional;

- Estreitar o relacionamento entre líder e liderado, ou melhor, entre avaliador e avaliado; 
- Promover o planejamento de um plano de desenvolvimento profissional alinhado com as diretrizes institucionais;

- Estabelecer o compromisso de desenvolvimento a ser gerenciado pelas partes durante o período.

A avaliação de desempenho verifica se o colaborador possui ou não as competências técnicas necessárias para exercer a função, apresentando os pontos fortes e os aspectos de melhoria. Procura, também, mapear as competências comportamentais adequadas para a realização do trabalho.

Para o avaliador é um desafio avaliar as competências comportamentais considerando a subjetividade que envolve o processo. Com o objetivo de eliminar a subjetividade do processo tradicional de avaliação, LEME (2006) cria a Metodologia do Inventário Comportamental para Mapeamento de Competências. Segundo o autor, é um método comprovado matematicamente para medir as competências comportamentais, tornando a avaliação precisa e objetiva e aumentando a eficiência do processo.

A avaliação de desempenho, quando bem aplicada, é um eficiente instrumento de apoio à gestão de pessoas, avaliando o colaborador sob vários aspectos do seu desempenho na organização. Pode ser realizada pela liderança imediata, por um par, por um cliente interno ou externo.

Todos precisam ser preparados tecnicamente para efetuarem a avaliação e, também, para serem avaliados. É imprescindível o estabelecimento de critérios claros para que a ferramenta de avaliação esteja alinhada com os objetivos de desenvolvimento das pessoas e com o alcance dos resultados empresariais. $\mathrm{O}$ sucesso de uma avaliação depende como a organização envolve os colaboradores e conduz o processo avaliatório. 
Todo o processo de avaliação não tem a finalidade de criar problemas, mas de solucioná-los. Assim, um aspecto fundamental para reflexão é a ética na utilização das ferramentas de avaliação. Para RABAGLIO (2006),

\footnotetext{
"Não importa se estaremos avaliando nosso melhor amigo ou nosso pior inimigo. $\mathrm{O}$ fato é que somos profissionais e que somos avaliados pela forma como avaliamos pessoas e, nesta atribuição, devemos colocar todo nosso profissionalismo, lealdade, integridade, justiça, comportamento ético e imparcialidade, e nos despirmos de rótulos, preconceitos, pressupostos, discriminações que possam influenciar a eficácia nos resultados da avaliação” (p.12).
}

A implementação do processo de avaliação de desempenho requer a atenção do líder para alguns pontos chaves, a fim de obter seu sucesso:

- Determinar o que e como será avaliado;

- Estipular um período de tempo entre a divulgação do início da avaliação e sua oficial aplicação pela empresa;

- Deixar claro o resultado esperado, que deve agregar tanto para o colaborador quanto para a organização, e como acontecerá a avaliação;

- Treinar os avaliadores esclarecendo os critérios que, além de claros, precisam ser mensuráveis e conhecidos por todos, bem como o período a ser avaliado;

- Apresentar os resultados ao avaliado para que este possa ter consciência dos seus pontos fortes e dos pontos as serem melhorados;

- Não assumir na avaliação o que não é possível de ser cumprido.

Para LEME (2006), o estabelecimento do período da avaliação é importante para a obtenção de resultados fidedignos e com menor subjetividade. Esse autor enfatiza que “...não quer dizer que o passado deva ser simplesmente esquecido, mas que a avaliação deve acontecer baseada em um determinado período, que tem seu início na data do empenho e término no início da avaliação” (p.17).

Nas instituições que estão alinhadas com a nova realidade do mercado, o importante é utilizar a avaliação de desempenho para o desenvolvimento ou aperfeiçoamento das competências do profissional. 
Dessa forma, verificar e avaliar apenas as competências técnicas e comportamentais ainda não é suficiente. É necessário analisar o que o colaborador entrega para a empresa, o nível de complexidade da sua função e seu espaço ocupacional.

Toda essa inquietude organizacional alavancou a gestão por competências que procura desenvolver a performance das pessoas em suas atribuições; fazer uso do potencial humano e melhorar a eficácia organizacional.

O alcance desses objetivos pode acontecer por meio da avaliação de desempenho com foco em competências, que se caracteriza por ser um trabalho consistente e integrado com as diretrizes da organização.

Segundo ELLIOT et al. (2000), avaliar competência é uma fase na qual a pessoa fica "atenta” em fazer bem uma atividade. Supõem uma intervenção direta no desempenho da tarefa. Mencionam, ainda, como é importante fazer bem a avaliação para iniciar um serviço, pois isso acaba influenciando na motivação interna do colaborador.

Na prática, o inicio do processo de avaliação, requer que cada cargo tenha as competências descritas e alinhadas aos processos de trabalho. Em seguida, deve ser usado um instrumento de avaliação para identificar as competências presentes no repertório técnico e comportamental do avaliado e identificar aquelas que necessitam de desenvolvimento ou aperfeiçoamento.

Assim, a avaliação com foco em competências é uma ferramenta que dá clareza e objetividade ao desempenho real e ao desempenho esperado para que, ambos, avaliador e avaliado, em conjunto, possam elaborar um plano de ação de desenvolvimento em busca do perfil e desempenho ideais. 
A entrevista da avaliação com foco em competências deve ser considerada uma ação estratégica para o líder que passa a compreender a necessidade de fazer gestão e desenvolvimento de pessoas, comprometendo-se com o crescimento e aperfeiçoamento de sua equipe.

Essa ação estratégica deve:

- Fortalecer os relacionamentos e a comunicação entre líder e equipe;

- Reconhecer e valorizar os pontos fortes do avaliado;

- Apontar de forma objetiva o que pode ser aperfeiçoado e desenvolvido;

- Mostrar as percepções do líder e as do avaliado;

- Fazer com que avaliador e avaliado estabeleçam um plano de desenvolvimento, bem como sua forma de acompanhamento para eliminar os gaps identificados.

Considerando seu caráter estratégico e também motivacional, a entrevista de avaliação deve ser planejada tanto pelo avaliador quanto pelo avaliado. Iniciar, conduzir e finalizar uma entrevista são cruciais para o avaliador, devendo-se:

- Proporcionar um ambiente de cordialidade que seja neutro;

- Ouvir com atenção e respeito as expectativas e as ansiedades do avaliado bem como sua auto-avaliação;

- Fornecer feedback positivo, reconhecendo e valorizando os pontos fortes;

- Fornecer feedback construtivo, identificando claramente as oportunidades de desenvolvimento;

- Ser imparcial na avaliação, mantendo o foco no período que está sendo avaliado.

Importante, ainda, é o avaliador deixar bem claro para a pessoa que a avaliação terá sua continuidade por meio do acompanhamento do plano de desenvolvimento, demonstrando interesse em ajudá-la naquilo que for necessário. 
É importante salientar que o método tradicional de avaliação de desempenho olha para o passado a partir dos requisitos técnicos que já ocorreram, enquanto que a abordagem da avaliação por competências vai direcionar o olhar para o futuro, ou seja, para o desenvolvimento das pessoas.

Em síntese, avaliar o desempenho com foco em competências torna-se uma prática desafiadora para o gerente-líder desde o momento da definição das competências por cargo, da estruturação do instrumento, do envolvimento e treinamento de todos, da implementação do processo, da análise dos resultados até o momento do acompanhamento dos planos de desenvolvimento ou aperfeiçoamento dos avaliados. Conhecer a arte de sua atuação no contexto de gestão de pessoas é o foco do próximo capítulo.

\subsection{ARTE DE SER LÍDER}

A globalização da economia, a competição dos mercados, o gerenciamento dos processos de trabalho e a importância do capital intelectual fazem surgir modelos administrativos direcionados à oportunidade e à necessidade de uma administração mais flexível e mais participativa. Assim, o chefe, com autoridade formal e, principalmente, controlador dos comportamentos dos subordinados, passa a ser uma figura ultrapassada nas organizações moderna.

No passado, parecia mais fácil supor que as pessoas se deixassem administrar e seguissem, sem questionar, as normas estabelecidas pelas organizações. Também, supunha, como viável, a possibilidade de mudar o comportamento das pessoas de acordo com os padrões determinados pelos cargos. O cargo de chefe/supervisor geralmente contava com alguém que acumulava respeitável conhecimento da organização e da tecnologia, mas não possuía o conhecimento para lidar com pessoas que é imprescindível para o sucesso do trabalho. Hoje, são completamente infrutíferas as tentativas de controle do comportamento 
humano. Apesar de tudo isso, raramente são encontrados nas instituições postos de chefias com verdadeiros líderes.

Em uma administração participativa é possível evidenciar que as pessoas estejam mais informadas, compreendendo claramente a relação entre o esforço despendido no trabalho e o alcance dos objetivos. Têm, também, melhor entendimento de quais padrões de comportamento serão recompensados ou não. Todo processo participativo desencadeia uma alavancagem motivacional da força de trabalho.

No contexto participativo, a figura do líder é destacada, porém, existe controvérsia entre os termos liderança e gerenciamento, sendo ambos necessários para o sucesso de uma empresa.

Conforme relata YUKL (2001), para alguns autores existem pessoas que são gerentes e outras que são líderes, apresentando características e valores distintos, ou seja, os gerentes se caracterizam por fazer as coisas certas (eficiência), enquanto que os líderes fazem certas as coisas (eficácia). Uma pessoa poderia ser um líder sem ser um gerente e outra seria um gerente sem saber liderar.

Já, outros autores, concebem liderança e gerenciamento como “processos distintos”, mas discordam que sejam processos estanques nas pessoas, isolando suas condutas. Dentre as competências gerenciais, a liderança seria o atributo fundamental do gerente.

YUKL (2001) faz referência a Rost quando define gerenciamento como um relacionamento de autoridade que existe entre o gerente e os subordinados para a produção de um serviço, enquanto que a liderança é visto como um relacionamento de influência entre líder e "seguidores”. Os gerentes poderiam ser líderes apenas se tivessem essa habilidade de influenciar pessoas para o alcance dos resultados. 
Ainda mencionando YUKL (2001), este pontifica a complexidade da liderança na medida em que enfatiza como sendo um processo de influenciar pessoas para que possam entender e aceitar quais necessidades devem ser atendidas e como isso deve ser feito de forma eficaz; é um processo de facilitar os esforços individuais e coletivos para alcançar os objetivos. Os líderes têm as seguintes características: traços (personalidade, valores, motivos), convicção e otimismo, habilidades e experiências na área de atuação, atitudes, integridade e ética, influência tática e atribuições sobre os seguidores.

A eficácia de uma liderança está profundamente ligada a alguns traços da personalidade do líder, tais como: alto nível de energia e tolerância ao estresse, autoconfiança, controle interior, estabilidade emocional e maturidade, integridade, motivação gerencial e elevado impulso para empreender. O sucesso também consiste em desenvolver habilidades nas dimensões interpessoal, cognitiva e técnica, pois depende da cultura organizacional e do nível de gerenciamento. Dentre as diversas habilidades, podem ser destacadas: persuasão, análise, comunicação, memorização dos detalhes, inteligência emocional/social, aprendizagem e adaptação a mudanças.

Coordenar e influenciar pessoas, em lugar de dirigí-las ou controlá-las, são os principais desafios do líder, que busca a eficácia dos processos de trabalho por meio de suas atitudes e das pessoas. O líder, atuando como um modelo de identificação favorável para o liderado, é o responsável pela sobrevivência do negócio. Servir de modelo, conseqüentemente, é uma combinação de caráter (quem você é como pessoa) e competência (o que você pode fazer).

A credibilidade para com a figura do líder torna-se fundamental, uma vez que o processo de liderança se caracteriza por esse relacionamento recíproco que existe entre aqueles que escolheram dirigir e aqueles que decidiram seguir. Para merecer credibilidade, o líder deve clarificar seus próprios valores que constituem nos padrões que guiam seus pensamentos, sentimentos e atitudes. 
Esses valores são traduzidos em um conjunto de princípios que são verbalizados aos liderados.

Reconstruir a credibilidade é um processo complexo que requer atenção diária dos líderes, os quais têm a missão de alimentar o relacionamento com seus seguidores; precisam ter tempo para agirem de forma consciente e consistente, pois, suas ações devem ser mais expressivas do que as suas palavras.

Portanto, o processo de autoconhecimento é um mecanismo impar do líder de manter viva essa credibilidade dos seus liderados por sua pessoa, pois, permite que ele compreenda e valorize as necessidades dos seus seguidores. Como registra BERGAMINI (1994), “O líder terá maior facilidade para chegar à compreensão do outro a partir do grau de conhecimento que tenha sobre si mesmo” (p.176). Além disso, esse processo, também habilita o líder a interagir com o ambiente social de uma forma mais ampla e eficaz.

Acredita-se que o líder necessita muito mais de habilidade interpessoal do que de habilidades técnicas e conceituais. A habilidade interpessoal é realmente importante quando se trabalha com grupos de pessoas e deve ser natural e contínua envolvendo certa sensibilidade do líder, não apenas no momento da tomada de decisão, mas também no seu comportamento diário.

Para o líder ser eficaz é necessário que essa habilidade interpessoal seja naturalmente desenvolvida e demonstrada por meio de suas atitudes. Utilizando sua sensibilidade interpessoal, ele irá distinguir as diferenças individuais dos liderados, posicionando-os em cargo que atendam, de forma apropriada, as necessidades e expectativas das pessoas.

A liderança não pode ser confundida como uma autoridade oficial, pois, muitas vezes o administrador imagina que sua posição no organograma lhe concede um grupo de seguidores sendo que, na verdade, tem apenas um grupo de 
subordinados. A eficácia de uma liderança dependerá do reconhecimento e aceitação dos liderados com relação a quem os pretenda dirigir.

Como foi mencionado por CORNETTA (2002),

"Uma característica básica do nosso líder é a sua capacidade de conduzir, com entusiasmo, toda a equipe. As estratégias devem ser transparentes, sem influências de "forças ocultas". O líder conhece, desenvolve e utiliza as habilidades de cada um; reconhece o bom desempenho e delega tarefas para que as pessoas, percebendo o significado, contribuam para o objetivo comum" (p.328).

O líder deve ser capaz de conduzir a organização e a equipe de trabalho tanto nos momentos de crescimento quanto nos períodos de crise. Conviver com a diversidade significa saber transitar por diferentes culturas e por diferentes dimensões políticas e econômicas. Nesse ambiente cada vez mais incerto e ambíguo, o líder necessita estabelecer referenciais perenes, os quais deverão estar alicerçados cada vez mais em valores, princípios e no comportamento ético (DUTRA, 2005). Paralelo a isso, ele precisa ser capaz de construir equipes comprometidas com o negócio, sem perder de vista as necessidades e desejos individuais das pessoas, alavancando a contribuição e o potencial de cada um.

Líderes que agregam valor aos seus seguidores são aqueles que ajudam as pessoas a se sentirem "poderosas” trabalhando entusiasticamente na direção dos objetivos. Dentre seus desafios, pode ser destacado o fato de desenvolver as pessoas, seus talentos e suas competências. Desenvolver pessoas não é apenas a ação de treiná-las e, sim, fazer com que se sintam valorizadas no trabalho; ampliar suas competências capacitando-as; fortalecer os aspectos éticos da organização educando-as; criar um clima onde elas possam se sentir motivadas no trabalho, contribuindo para o sucesso da empresa.

A liderança, também, deve saber como lidar com situações de conflitos que trazem conseqüências positivas ou negativas dependendo do seu modo de agir. Alguns líderes podem ter anseio de liderar pelo conflito, mas não sabem como 
fazê-lo. Outros preferem explorar o conflito em benefício próprio. E existem aqueles que com habilidade conseguem transformar o conflito em oportunidade de aprendizado e de transformá-lo em forças positivas para atingir propósitos maiores.

Liderar, superando conflitos, exige do líder competências especificas, tais como: ação global, visão sistêmica, confiança ao promover diálogo entre as partes e inovação. Como foi enfatizado por GERZON (2006) existe uma carência de tais líderes e os que conseguem liderar por meio dos conflitos estão com tudo.

Toda liderança deve reconhecer os esforços positivos de cada membro de sua equipe. Para isso, é importante estabelecer um sistema eficaz de avaliação de desempenho que permita um relacionamento e diálogo franco onde o avaliador e o avaliado devam saber exatamente o que será avaliado. Aprender a trabalhar os erros de forma construtiva e aproveitar os conhecimentos, a técnica e a experiência das pessoas são inerentes ao papel de líder.

A prática da liderança pode ser avaliada e percebida pelo reconhecimento das aptidões e limites do grupo, pelo incentivo ao treinamento e desenvolvimento das competências (sobretudo as interpessoais), pelas avaliações periódicas do desempenho e, pelo clima de reconhecimento e valorização dos acertos.

Querer liderar e acreditar que pode fazê-lo são os primeiros passos no caminho da liderança. Sabe-se que o processo de liderança é uma arte e que o instrumento do artista é ele mesmo. Portanto, o autodesenvolvimento contínuo consiste na ferramenta imprescindível para o líder.

Poucas empresas se têm dado conta da sinergia organizacional e humana que é desperdiçada pela realidade de não possuírem líderes eficazes. Apresentam na sua estrutura muitos diretores/chefes/supervisores que raramente conseguem gerar um ambiente que integre satisfação, produtividade e motivação. 
As organizações devem compreender as transformações do processo de liderança e a cultura organizacional, para estimular e reforçar o comportamento de verdadeiros líderes. Esse é, também, um desafio das instituições hospitalares que é o foco do próximo item.

\subsection{GESTÃO HOSPITALAR}

As organizações estão descobrindo que precisam agir de modo diferente para sobreviver à competitividade que caracteriza o mercado atual.

É evidente que compreender as mudanças do cenário moderno é tão vital para o gerenciamento de uma empresa quanto administrar os problemas do dia-a-dia. Uma gestão não articulada com a realidade pode passar por obstáculos mais imediatos e comprometer a sobrevivência da organização.

Por outro lado, uma gestão dirigida sem um olhar para o amanhã corre o risco de ser apanhada de surpresa por transformações que podem ocorrer nos clientes, nos fornecedores, no próprio cenário econômico, enfim em todo o ambiente (interno e externo), sem tempo da organização poder reagir de forma eficaz. Nesse contexto, é essencial aos gestores-líderes estarem acima de tais turbulências, procurando enxergar as transformações de forma mais ampla e consistente.

Toda mudança é uma tarefa bem difícil. No mundo organizacional não é diferente. Muitas vezes é mais fácil abrir uma nova empresa do que fazer mudanças, pois se deve respeitar principalmente a sua cultura.

A cultura de uma organização é aquela que define suas fronteiras, que gera a identidade nas pessoas que nela trabalham e que facilita o comprometimento das pessoas com algo maior do que os seus interesses individuais, estimulando a 
estabilidade. Toda cultura é percebida por meio dos seguintes elementos, segundo TACHIZAWA et al. (2006):

1. “Ambiente dos negócios constituído pelos competidores, clientes, tecnologia e outros fatores;

2. Valores são a crença do negócio e de como conduzí-los pelos membros da organização;

3. Heróis são aqueles que na organização personificam a cultura e os valores constituindo exemplos para os outros;

4. Rituais que mostram às pessoas o tipo de comportamento que delas é esperado;

5. Rede cultural significa os modos como se transmite a cultura a seus membros” (p.108-109).

Assim, o diferencial competitivo de toda organização que foca o sucesso acontece pela atenção direcionada aos elementos citados. Aquelas empresas que são eficientes e eficazes por meio da atuação de pessoas satisfeitas e motivadas alcançam o sucesso, em virtude da existência de uma cultura forte, enquanto que outras, caracterizadas por conflitos internos e desmotivação dos trabalhadores, não têm a mesma sorte. A cultura organizacional é um fator importante que pode explicar o sucesso econômico.

A competitividade consiste na capacidade da empresa formular e implementar estratégias que lhe permitam conservar de forma permanente sua posição de mercado. Seu desempenho competitivo, além da cultura organizacional, está ligado à existência de novas tecnologias e aos modelos de gestão inovadores que vêm transformando o sistema produtivo e exigindo cada vez mais a capacidade intelectual dos colaboradores.

No novo cenário econômico, o capital intelectual é fator estratégico, sendo um diferencial competitivo quando bem gerenciado. Por esse motivo, as pessoas devem ser reconhecidas e valorizadas, pois são elas que agregam valor ao negócio. 
Pouco a pouco, as empresas vão se conscientizando de que precisam ser ágeis para acompanhar as modificações do mercado, e que a redução de custos bem como o aumento da eficiência somente serão obtidos se as estruturas departamentalizadas derem lugar à integração das áreas e à participação das pessoas.

Em vista disso, as organizações são mais pressionadas a investirem no desenvolvimento de seus colaboradores para conquistarem vantagens e de continuarem cada vez mais competitivas.

Por outro lado, também as pessoas se dão conta de que precisam se aperfeiçoar de forma contínua, sendo esta uma condição para a inserção ou manutenção no mercado de trabalho.

Para permitir que as instituições acompanhem e se antecipem as rápidas mudanças, surge uma nova abordagem gerencial direcionada à valorização do ser humano. Esse novo estilo de gerenciamento é chamado de gestão de pessoas, cujo princípio consiste em encantar o colaborador para que este encante os clientes.

A criação de um ambiente focado no monitoramento, no controle e melhoria dos processos de trabalho e no aprendizado contínuo dos colaboradores faz com que as organizações sejam capazes de oferecer aos clientes o que eles desejam, quando e como.

Nos dias de hoje, as instituições não mais prometem segurança e estabilidade aos seus funcionários. Uma empresa, para ser reconhecida externamente, necessita ter não apenas a eficiência e a eficácia dos seus processos (produtos, apoio, fornecedores e financeiros), mas, principalmente, o ânimo e a motivação das pessoas para o trabalho. Ter visão sistêmica dos processos e, sobretudo, tratar os funcionários como parceiros constitui um grande desafio gerencial. 
Faz sentido, atualmente, compreender porque as empresas estão cada vez mais preocupadas com seu capital intelectual e estão mais atentas às competências que aprimoram o nível técnico e o comportamento dos colaboradores, pois a sobrevivência das empresas e o aumento dos resultados dependem diretamente das pessoas.

A valorização e o reconhecimento das pessoas são as palavras-chave para uma profunda mudança nos processos e nos resultados de uma empresa, pois fazem com que os colaboradores estejam mais próximos da organização resultando, consequentemente, no seu comprometimento com o negócio.

O contexto da atualidade e suas implicações de gestão de pessoas precisam ser refletidos nos hospitais e outras instituições de saúde porque também estão inseridos nas condições do mercado, sofrendo as influências políticas, sociais, econômicas e tecnológicas. Os hospitais prestam serviços à sociedade e têm a obrigação de serem fiéis aos propósitos de promover a saúde, prevenir a doença, diagnosticar, tratar e reabilitar o cidadão dentro de um bom padrão técnico e excelente nível de humanização. Seus colaboradores, como pessoas comprometidas, qualificadas e motivadas, são considerados os únicos "recursos” voltados à prestação de serviços com qualidade ao cliente fragilizado.

No entanto, observa-se uma carência significativa de pessoas comprometidas e participativas com o negócio saúde. As pessoas que trabalham com a saúde sentem falta de um ambiente sinérgico, cooperativo e com possibilidades de crescimento. Seus líderes ou administradores lidam insatisfatoriamente com as necessidades e expectativas dos colaboradores e dos usuários.

O hospital é considerado uma instituição autoritária, fortemente alicerçada em rotinas e normas rigidamente estabelecidas pelos gerentes, e regras muitas vezes inflexíveis a serem cumpridas pelos colaboradores. Tal rigidez e inflexibilidade não fornecem espaço para o aprendizado. Sabe-se que o ciclo contínuo do 
aprendizado acontece quando os colaboradores são estimulados a melhorar os processos, a tomar consciência dos erros, a introduzir melhorias e a propor solução para os problemas.

O ambiente hospitalar compreende diversas categorias profissionais que estão inseridas em uma estrutura funcional específica e devem assegurar, por meio do trabalho em equipe, a prestação de serviço adequado ao cliente.

Todo profissional, que vem desenvolver qualquer tipo de trabalho no hospital, precisa ter em mente de que o hospital é um prestador de serviço, e que todo cliente que o procura necessita de assistência nos diferentes níveis de complexidade de atenção à saúde, ou seja, todos devem compartilhar de uma única missão: atendimento e recuperação do doente.

O relacionamento entre todos os membros de equipe é fundamental para que o hospital possa realizar sua missão. Todos dependem de todos. Tudo deve funcionar de uma forma sistêmica, ou seja, os colaboradores devem interagir como um todo, difundindo ou complementando informações que, uma vez integradas, irão construir a melhor conduta e cuidados na recuperação da saúde.

Considerar a força de trabalho como parceiros é muito importante na organização hospitalar para o alcance de seu objetivo principal que consiste no atender o doente com respeito e ética.

O ambiente de cooperação é o diferencial de qualquer hospital, pois além de minimizar a tensão no ambiente, faz com que a organização alcance suas metas a partir do feedback do desempenho das suas equipes.

Todo trabalho de equipe exige que os colaboradores conheçam bem as atividades, necessidades e dificuldades de seu setor, bem como de colegas de outros setores mantendo, assim, uma relação recíproca de respeito, ajuda e solidariedade. 
No hospital, os colaboradores que contribuem com seus esforços, conhecimentos e competências, esperam, conseqüentemente, receber salários, benefícios, retribuições e satisfação. Tais pessoas necessitam de outras, consideradas líderes. Esses líderes são os responsáveis pela dinâmica das atividades, a partir de sua influência na equipe.

Para uma verdadeira gestão de pessoas em saúde, o papel do líder é muito importante. Seus valores, crenças e motivação trazem, para o hospital, o real comprometimento que faz a ligação das pessoas com os processos de trabalho.

Quem atua numa instituição de saúde deve estar motivado e satisfeito, deve fazer o serviço com disposição, ouvindo e transmitindo coisas boas, por meio de gestos e palavras, ao cliente que está fragilizado, esclarecendo dúvidas e minimizando preocupações. Isso permite a criação de um ambiente humanizado que é o resultado do comprometimento de todos para com o hospital, pois se as pessoas estiverem motivadas, com certeza esse bem-estar será irradiado para os diversos setores de trabalho, que prestarão uma assistência personalizada ao cliente com muito mais qualidade.

Para BERTELLI (2004), “A liderança é um fenômeno tipicamente social que ocorre exclusivamente em grupos e nas organizações. É uma influência interpessoal exercida numa dada situação e dirigida através de um processo de comunicação humana para consecução de um ou mais objetivos” (p.36).

Nas instituições hospitalares, os líderes podem estar presentes nos papéis formais de chefe, diretor, encarregado, supervisor ou gerente como, também, coordenando equipes apesar de não possuírem vínculos a cargo. De qualquer forma, ao exercitarem a liderança, eles transmitem aos seus liderados confiança, motivação, orientações, buscando, também, a participação de todos na tomada de decisão. 
Os líderes possuem diversas características pessoais, intelectuais, emocionais e físicas. Sabe-se que o sucesso ou a destruição de uma empresa depende das características e estilos dos líderes.

Na medida em que a organização opta por uma gestão participativa, enxergando os recursos humanos como os seus “ativos” mais valiosos, ela está no caminho certo. Porém, o estilo mais observado de liderança na área hospitalar é aquele caracterizado pela centralização, poder nas mãos de poucos e, de modo geral, o médico detendo o maior poder. 


\section{MÉTODO DE PESQUISA}

\subsection{TIPO DE PESQUISA}

De acordo com PROETTI (2005), “... a metodologia tem o objetivo de organizar e dar seqüência às atividades da pesquisa para nos aproximar do objetivo desejado. É através dos métodos e processos que o investigador pode intervir na realidade, interagir com ela e produzir conhecimento científico” (p.75). Quanto à caracterização das pesquisas, conforme a coleta de dados, para o mesmo autor, os procedimentos de coletas são os métodos práticos, utilizados para unir e relacionar os dados coletados, para a construção lógica dos raciocínios que compõem fatos, fenômenos ou problemas.

Segundo ALVES-MAZZOTTI (1999), o método qualitativo tem como principal característica o fato de que segue a tradição compreensiva ou interpretativa, parte do pressuposto de que as pessoas agem em função de suas crenças, percepções, sentimentos e valores e que seu comportamento tem sempre um sentido, um significado que não dá a conhecer de modo imediato precisando ser desvendado. Para ele, a maior parte das pesquisas qualitativas tem como finalidade preencher lacunas no conhecimento sendo consideradas exploratórias. Tais lacunas consistem na compreensão de processos que acontecem em uma instituição, grupo ou comunidade.

A pesquisa qualitativa, de acordo com MINAYO (1994), é adequada para a interpretação de uma realidade. Para IERVOLINO e PELICIONI (2001), os procedimentos qualitativos são utilizados quando o pesquisador quer investigar como as pessoas avaliam uma experiência, idéia ou evento; como as pessoas definem um problema e quais as opiniões, os sentimentos e os significados que estão associados ao fenômeno. 
Na abordagem qualitativa, quando comparada com a quantitativa (Quadro 2), é realizado estudo mais profundo sobre a problemática dos fenômenos sociais, suas especificidades em termos de origem e sua razão de ser, sendo utilizadas amostras pequenas para aprofundamento do assunto e refinamento dos resultados. Visa trabalhar mais com a observação e relatos dos entrevistados.

Os padrões exibidos na pesquisa quantitativa podem ser enriquecidos e melhor compreendidos com o acréscimo das informações qualitativas, como os sentimentos, impressões e motivações das pessoas que compõem a amostra.

Cabe mencionar que as técnicas qualitativas envolvem questionamentos abertos e sondagens, detectando problemas despercebidos em um estudo quantitativo. Os dados são ricos, humanos, sutis e muitas vezes reveladores. Por outro lado, é importante ter em mente que amostras reduzidas e discussões grupais podem conduzir uma pesquisa qualitativa para muitas direções, necessitando um moderador muito hábil na condução do grupo, para o alcance dos objetivos propostos.

Quadro 2 - Pesquisa qualitativa versus pesquisa quantitativa

\begin{tabular}{|l|l|l|}
\hline Dimensão de comparação & Pesquisa qualitativa & Pesquisa quantitativa \\
\hline Tipo de pergunta & $\begin{array}{l}\text { Perguntas com grande } \\
\text { profundidade }\end{array}$ & $\begin{array}{l}\text { Perguntas com profundidade } \\
\text { limitada }\end{array}$ \\
\hline Tamanho da amostra & Gequena & Varia \\
\hline Informações por entrevistado & Muitas com & $\begin{array}{l}\text { Menos habilidades especiais } \\
\text { requeridas. }\end{array}$ \\
\hline Administração & $\begin{array}{l}\text { Requer entrevistadores } \\
\text { habilidades especiais. }\end{array}$ & Estatística, sumarização \\
\hline Tipo de análise & $\begin{array}{l}\text { Gravadores, projetores, vídeo, } \\
\text { fotos, guias de discussão. }\end{array}$ & $\begin{array}{l}\text { Questionários, } \\
\text { computadores, documentos } \\
\text { impressos. }\end{array}$ \\
\hline Hardware & Exploratória & Descritiva ou causal \\
\hline Tipo de pesquisa &
\end{tabular}

Fonte: Adaptado de McDANIEL, Carl; GATES, Roger. Pesquisa de marketing. São Paulo: Thomson Learning, 2006. p.121.

A técnica de Grupo Focal visa discutir profundamente determinado assunto, tópico ou conceito a partir da interação dinâmica das pessoas de um grupo, onde a 
resposta de uma pessoa pode se tornar estímulo para a outra, gerando discussões ricas, focadas em tópicos específicos e diretivos, conduzidas por um moderador habilidoso.

O Grupo Focal é considerado técnica de pesquisa qualitativa apresentando como características o baixo custo e a rapidez com que os dados são fornecidos, validados e confiáveis (IERVOLINO e PELICIONI, 2001). Os participantes precisam ter alguma vivência com o tema a ser discutido, trazendo, durante o trabalho interativo, contribuições relevantes ancoradas em suas experiências cotidianas.

Segundo McDANIEL (2006),

“A meta da pesquisa de grupo de foco é saber e compreender o que as pessoas têm a dizer e por quê. Nela, a ênfase está em fazer com que as pessoas falem à exaustão e detalhadamente sobre o assunto escolhido. A intenção é descobrir o que elas sentem em relação a um produto, um conceito, uma idéia ou uma organização, como tudo isso se encaixa na vida delas e seu envolvimento emocional com essas coisas” (p.123).

Os Grupos Focais apresentam algumas vantagens e desvantagens, como evidenciadas no Quadro 3.

\section{Quadro 3 - Vantagens e desvantagens da técnica de Grupo Focal}

\begin{tabular}{|l|l|}
\hline \multicolumn{1}{|c|}{ Vantagens } & \multicolumn{1}{|c|}{ Desvantagens } \\
\hline $\begin{array}{l}\text { Interação entre os entrevistados estimula novos } \\
\text { pensamentos e idéias. }\end{array}$ & $\begin{array}{l}\text { Resultados podem iludir, mascarar em vez } \\
\text { de informar. }\end{array}$ \\
\hline $\begin{array}{l}\text { Informações relevantes fornecidas em menor } \\
\text { tempo. }\end{array}$ & Abordagem indutiva. \\
\hline $\begin{array}{l}\text { Considerada uma técnica rápida de pesquisa. } \\
\text { Resultados mais facilmente compreendidos; } \\
\text { possuem imediatismo e entusiasmo. }\end{array}$ & $\begin{array}{l}\text { Composição do grupo (personalidade de } \\
\text { cada entrevistado; impessoalidade) e } \\
\text { tendenciosidade do moderador da discussão. }\end{array}$ \\
\hline
\end{tabular}

Fonte: Extraído de McDANIEL, Carl; GATES, Roger. Pesquisa de marketing. São Paulo: Thomson Learning, 2006. p.134 - 136. 
De acordo com Morgan e Krueger citados por GATTI (2005), “... a pesquisa com grupos focais tem por objetivo captar, a partir das trocas realizadas no grupo, conceitos, sentimentos, atitudes, crenças, experiências e reações, de um modo que não seria possível com outros métodos, como, por exemplo, a observação, a entrevista ou questionários” (p.9).

A partir das informações sobre os métodos de pesquisa analisados e, em resposta ao objetivo geral deste estudo, a técnica de Grupo Focal foi considerada relevante, pois possibilitou extrair das lideranças informações e opiniões sobre avaliação de desempenho, bem como os sentimentos, satisfação e insatisfação, recompensas e frustrações sobre o assunto, revelando os aspectos fundamentais para a eficiência desse processo.

\subsection{LOCAL DA PESQUISA}

O estudo foi desenvolvido em hospital público da cidade de São Paulo, especializado em cardiologia, apoiado por uma fundação. Apresenta em sua missão-visão a excelência e referência na assistência, ensino e pesquisa, nacional e internacionalmente.

O diferencial desse hospital está na produção da ciência médica com qualidade, voltada ao paciente de alta complexidade. É, também, destaque nas inovações tecnológicas e na formação de profissionais por meio do ensino médico, da especialização multiprofissional, da capacitação e desenvolvimento de sua força de trabalho.

Características do hospital escolhido para pesquisa:

1. Capacidade de funcionamento acima de 300 leitos;

2. Natureza geral de nível terciário de cuidados à saúde;

3. Atendimento a pacientes SUS, conveniados e particulares; 
4. Realiza, por ano, aproximadamente 266 mil consultas, 14 mil internações, 4 mil cirurgias e 2 milhões de exames de diagnóstico (Ano-Base: 2007);

5. Quadro funcional de aproximadamente 2.738 colaboradores (Ano-Base: 2007) sendo, 257 (9\%) com Cargos de Chefia/Lideranças, assim distribuídos:

a) Chefias Nível Universitário: 113

b) Chefias Nível Médio: 55

c) Chefias Nível Fundamental: 3

d) Diretores: 86

O hospital vem procurando desenvolver uma estrutura organizacional enxuta. Seu estilo de gerenciamento apresenta mudanças, de forma que todas as suas atividades estejam direcionadas para sua auto-sustentabilidade, seu alto desempenho e maior envolvimento da sua força de trabalho. Assim, seu sistema de liderança é participativo, dinâmico nos processos de trabalho e focado em resultados, trazendo como vantagens:

1 Interações efetivas da diretoria executiva com os diretores e gerentes de linha;

2 Coesão e alinhamento das áreas às diretrizes institucionais;

3 Atuação horizontal dos profissionais de nível gerencial e de linha, em esquema matricial, para melhorias dos processos de trabalho, flexibilizando as relações de poder, motivando-os e otimizando custos;

4 Disseminação objetiva e compartilhamento de informações com os colaboradores;

5 Acompanhamento dos processos de trabalho, evitando retrabalho e perda de tempo;

6 Busca intensiva da equipe por resultados.

Cabe mencionar que nesse hospital público, na época em que o estudo foi desenvolvido, os processos de avaliação visavam a efetivação do funcionário na organização (período de experiência e um ano após admissão na área). No passado, a avaliação de desempenho gerava decepções, desmotivação e um clima 
de insatisfação para quase todos os funcionários do hospital. Portanto, esse processo estava passando por uma reestruturação.

\subsection{UNIVERSO OU POPULAÇÃO}

O universo da pesquisa compreendeu os líderes que integram esse hospital público da cidade de São Paulo, especializado em cardiologia. Eles, além da competência técnica, possuem a capacidade de conduzir, com entusiasmo, toda a equipe de trabalho para o alcance dos resultados, demonstrando comprometimento com os valores e as diretrizes da organização.

Eles recebem a denominação de gerentes, supervisores, chefes e encarregados, de acordo com a estrutura de recursos humanos, sendo considerados líderes formais, perfazendo total de 257 (9\% da população total do hospital).

Existem, também, na instituição aquelas pessoas que, mesmo não estando em um cargo de chefia, gerenciam os processos de trabalho e possuem uma atitude e postura que denotam confiança e coerência em suas decisões, alavancando o potencial dos funcionários e reconhecendo o desempenho dos mesmos. São denominados líderes informais que se destacam no desenvolvimento dos trabalhos, gerenciam conflitos e lidam com pessoas e grupos. Não foi possível quantificar essa população.

\subsection{AMOSTRA}

O termo amostra refere-se a um subconjunto representativo da população total de interesse, extraindo-se dele informações que servem de estimativas sobre as características do todo. 
Para Marshall citado por TEIXEIRA (1998), “O tamanho apropriado de uma amostra para um estudo qualitativo é aquele que adequadamente responde as questões do pesquisador” (p.25).

Para o presente estudo foi utilizada amostra intencional de líderes (formais e informais), garantindo a variabilidade da mesma, com critérios previamente definidos e descritos no item 6.5 SUJEITOS DA PESQUISA, sendo capazes de transmitir as informações necessárias para o alcance dos objetivos propostos.

Um cuidado importante foi convidar formalmente e pessoalmente as lideranças com intervalo de 15 dias de antecedência da realização do grupo focal. Outro contato informal da pesquisadora com os participantes foi por telefone, no dia anterior da discussão, com o objetivo de confirmar a presença deles e obter a viabilidade da amostra.

Não houve a preocupação estatística considerada obrigatória em pesquisas quantitativas ao selecionar amostras representativas do universo de líderes, mas, sim, de garantir, pela sua variabilidade, que as mais diversas opiniões, percepções e sentimentos dos participantes sobre o assunto fossem manifestados.

\subsection{SUJEITOS DA PESQUISA}

São os líderes formais e informais de diversas áreas da instituição, escolhidos intencionalmente pela pesquisadora, a partir de uma relação nominal retirada do sistema de informação de recursos humanos da instituição. Teve-se o cuidado de tornar representativa a maior parte das áreas assistencial, de apoio e administrativa.

Assim, participaram líderes das seguintes áreas: Cirurgia-Anestesia, Enfermagem (Internação Geral, Pediatria e Emergência), Farmácia, Gestão do Fator Humano, Engenharia de Manutenção, Infra-estrutura e Logística, Serviço 
de Apoio Diagnóstico e Terapêutico, Laboratório Clínico, Anatomia Patológica, Odontologia, Gerência de Risco, Saúde Suplementar, Faturamento, Assessoria de Comunicação Social, Bioengenharia, Unidade de Atendimento ao Paciente Ambulatorial e de Informações Médicas.

Os critérios para a escolha dos líderes foram principalmente por:

a) Terem avaliado o desempenho de sua equipe, utilizando instrumentos formais do hospital.

b) Terem sido submetidos ao processo institucional de avaliação de desempenho e, portanto, possuírem opiniões sobre os pontos fortes e as melhorias do mesmo.

\subsection{COLETA DE DADOS}

A coleta dos dados, por meio dos grupos focais, teve como riqueza basear-se na tendência humana de formar opiniões e atitudes a partir da interação com outras pessoas.

O trabalho foi realizado com 3 grupos focais, com variação de 8 a 11 componentes cada um $\left(1^{\circ}\right.$ grupo $=11,2^{\circ}$ grupo $=8$ e $3^{\circ}$ grupo $\left.=10\right)$, compreendendo líderes de diferentes profissões e ambos os sexos, perfazendo total de 29 lideranças.

Foi realizada uma reunião com cada grupo, por meio da qual se procurou conhecer o processo de avaliação de desempenho, os sentimentos e percepções das pessoas sobre o assunto que consiste o foco da pesquisa.

Os grupos foram coordenados e conduzidos pela pesquisadora e constou de 4 etapas: 


\section{Quanto ao preparo do local para a dinâmica de grupo}

O local, para o desenvolvimento dos trabalhos com o grupo focal, foi em uma sala de aula, no $2^{\circ}$ andar do hospital, previamente reservada e preparada para que diferentes percepções e pontos de vista viessem à tona. As cadeiras foram dispostas em círculo onde dois pequenos gravadores e microfone fizeram parte do cenário.

Foi garantido um clima confortável e descontraído para que houvesse a troca de experiências e impressões entre os participantes que, muitas vezes, foi de caráter pessoal.

\section{Quanto ao recrutamento dos participantes}

A partir da relação de líderes, obtida pelo sistema informatizado da área de recursos humanos, foi elaborada, pela pesquisadora, uma carta convite (Anexo 1) e entregue, pessoalmente, para cada líder explicando o objetivo da pesquisa e a dinâmica do grupo focal. Nesse momento, iniciou, assim, um processo de interação entre as partes envolvidas. Nesse contato, foi obtida, também, a possibilidade ou não do líder participar da coleta de dados.

Foi evitado alocar em um mesmo grupo, pessoas do mesmo círculo imediato de convivência ou que apresentassem características muito contrastantes, para que não houvesse nem confrontos e nem bloqueios nas opiniões manifestadas por cada membro do grupo.

\section{Elaboração do guia de discussão}

O guia de discussão consistiu de 7 tópicos sobre avaliação de desempenho, abordados durante as discussões com os grupos focais (Anexo 2). As 
perguntas elaboradas tiveram um caráter geral sobre o assunto a fim de estimular a discussão livre e espontânea das pessoas.

A dinâmica das reuniões apresentou momentos detalhados na estrutura do guia como a criação de um ambiente receptivo entre pesquisadora e participantes, esclarecimentos sobre grupo focal, das regras de interação e apresentação dos objetivos do estudo, questionamento e provocação dos participantes para discussão.

\section{A condução do grupo focal}

Na medida em que os participantes chegavam à sala de reunião, recebiam uma folha (Anexo 3) para ser preenchida individualmente, visando obter informações gerais, tais como data de nascimento, sexo, data de admissão no hospital, nome do cargo que ocupa, tempo no cargo atual, jornada de trabalho e número de funcionários que estão sob sua responsabilidade. O termo de consentimento livre esclarecido para participação em trabalho científico (Anexo 4) também foi entregue para leitura e assinatura.

Cada reunião teve duração aproximada de duas horas, assim distribuídas:

1. 15 minutos iniciais: para apresentações e explicações sobre o funcionamento da dinâmica do grupo, enfatizando que não se buscava o consenso nas discussões e que as divergências de opiniões e de experiências eram extremamente importantes. Foi também solicitado ao grupo consentimento para ser efetuada a gravação dos comentários, mencionando a garantia do total sigilo das informações obtidas.

2. 8 a 10 minutos: para cada membro do grupo focal se manifestar sobre os tópicos que foram conduzidos pela pesquisadora a partir do guia de discussões. 
Um observador, indicado pela pesquisadora, permaneceu afastado dos grupos, na mesma sala, anotando as reações dos líderes e sentimentos manifestados, auxiliando, também, nas observações da comunicação não verbal.

Durante a condução da dinâmica, a pesquisadora teve flexibilidade e firmeza para solicitar esclarecimentos e aprofundamento, conduzir o grupo para o próximo tópico, estimular os tímidos, colocar limites naqueles que não paravam de se manifestar e finalizar as atividades do grupo.

Ao término de cada grupo focal, as fitas eram transcritas.

\subsection{ANÁLISE DOS DADOS}

A partir da transcrição das fitas, a análise minuciosa das discussões foi imprescindível para conhecer realmente aquilo que estava por trás das manifestações dos líderes, ou seja, enriquecer a leitura tendo a certeza da interpretação realizada do conteúdo, trazendo a idéia principal que é suficiente para o objetivo proposto no estudo.

Adotou-se, portanto, o método de análise de conteúdo que, segundo BARDIN (1988),

“É o método das categorias, espécie de gavetas ou rubricas significativas que permitem a classificação dos elementos de significação constitutivas da mensagem (...) visa o conhecimento de variáveis de ordem psicológica, sociológica, histórica, etc, por meio de um mecanismo de dedução com base em indicadores reconstruídos a partir de uma amostra de mensagens particulares” (p.37 e 44). 
A partir do conteúdo das discussões de cada grupo focal foi possível organizar o material coletado, separando-o em 5 categorias que serão detalhadas no item 7 RESULTADOS E DISCUSSÃO. Essa categorização apresenta os elementos comuns dos discursos, propiciando o conhecimento do processo de avaliação de desempenho, das expectativas, dos sentimentos, das atitudes e das contribuições das lideranças para a eficiência do mesmo.

\subsection{PROCEDIMENTOS ÉTICOS}

O planejamento, a organização e a execução do estudo, bem como a análise das informações obtidas pelos líderes estiveram alicerçados nos princípios éticos norteadores das pesquisas científicas.

Para elaborar o projeto, a autora tomou os devidos cuidados a fim de que o mesmo obtivesse a anuência das comissões éticas da instituição de ensino, na qual a pesquisadora é discente, e do hospital eleito para o estudo, no qual a mesma é funcionária.

Segundo GUERRIERO (2006), “A Resolução 196/96 - Conselho Nacional de Saúde (CNS) incorpora a necessidade de informar os participantes sobre os procedimentos da pesquisa, de maneira a possibilitar e garantir o respeito à decisão dela participar ou não” (p.47).

Assim, o termo de consentimento livre esclarecido para participação do trabalho científico foi apresentado a cada participante para a coleta dos dados. Após leitura do documento, compreensão dos objetivos da pesquisa, da ausência de danos físicos e morais e da confidência dos dados, o mesmo era assinado pelos participantes para iniciar a atividade. Os líderes tinham a liberdade de não aceitarem a participar do estudo. 
Segundo GUERRIERO (2006), este menciona um aspecto importante que é a relação entre pesquisador e pesquisado.

"Uma das características comuns a vários métodos qualitativos é que o pesquisador é o próprio instrumento, e, em determinadas pesquisas, o fato de conhecer bem o participante o coloca numa situação privilegiada para compreender, de maneira mais profunda, a situação. Também para o participante, se o que estiver em estudo implicar em questões íntimas, pode ser mais fácil responder para alguém que já conhece, (...)” (p.57).

No contexto mencionado por GUERRIERO, cabe mencionar que a pesquisadora atua na instituição há mais de 20 anos. Em seu cargo de assistente, desenvolve trabalhos em gestão de pessoas, alguns em parceria com as diversas áreas do hospital, porém não conflitou em nenhum momento com as lideranças formais ou informais, e nem interferiu na coleta dos dados.

Foi consenso de todos os líderes a relevância do assunto, pois a partir de uma avaliação estruturada alinhada à estratégia da instituição possa existir a melhoria contínua do desempenho profissional e a implementação de outras ações de recursos humanos voltadas ao benefício do funcionário, da própria liderança e da organização. 


\section{RESULTADOS E DISCUSSÃO}

Neste estudo, os dados constituem os resultados das três atividades de grupo focal, realizadas em 2006, com 29 lideranças de diversas áreas do hospital.

$\mathrm{Na}$ primeira parte, será apresentado um foco quantitativo, evidenciando a caracterização dos líderes quanto à idade, ao sexo, ao tempo na instituição, à profissão, ao nome do cargo atual, ao tempo no cargo atual, à jornada de trabalho e ao número de funcionários sob sua responsabilidade.

Na segunda parte, os dados serão descritos e analisados qualitativamente destacando as expectativas, os sentimentos e as atitudes das lideranças frente ao processo de avaliação de desempenho, bem como suas contribuições para a eficiência do mesmo.

\section{1 $1^{\mathrm{a}}$ PARTE - CARACTERIZAÇÃO DOS LÍDERES}

\subsubsection{Quanto à idade}

Gráfico 1 - Caracterização das lideranças quanto à faixa etária

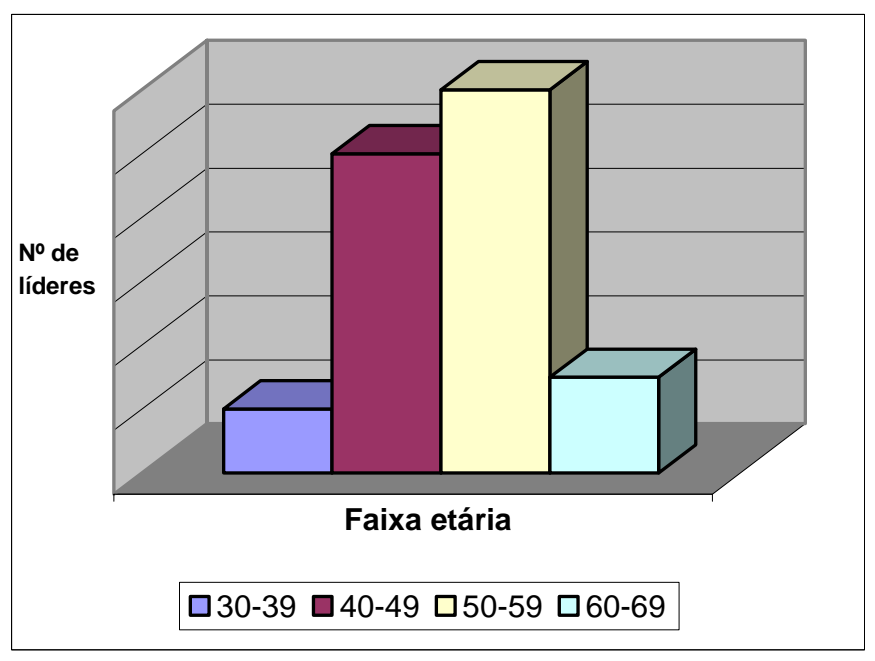

\begin{tabular}{|c|c|c|}
\hline $\begin{array}{c}\text { Faixa } \\
\text { etária }\end{array}$ & $\begin{array}{c}\mathbf{N}^{\mathbf{0}} \\
\text { líderes }\end{array}$ & $\mathbf{\%}$ \\
\hline $30-39$ & 2 & 8 \\
\hline $40-49$ & 10 & 37 \\
\hline $50-59$ & 12 & 44 \\
\hline $60-69$ & 3 & 11 \\
\hline Total & $\mathbf{2 7}$ & $\mathbf{1 0 0}$ \\
\hline
\end{tabular}


Observa-se que 44\% (12) dos líderes estão na faixa etária de 50 a 59 anos e que 37\% (10) na faixa de 40 a 49 anos. O líder é aquele que tem experiência profissional e conhecimentos da cultura organizacional, habilidade em gestão de pessoas e a competência técnica específica procurando a melhoria dos processos de trabalho. Pode-se inferir que o conjunto dessas qualidades adquiridas permite aos líderes um conhecimento abrangente da aplicabilidade da avaliação de desempenho.

\subsubsection{Quanto ao sexo}

Gráfico 2 - Caracterização das lideranças quanto ao sexo

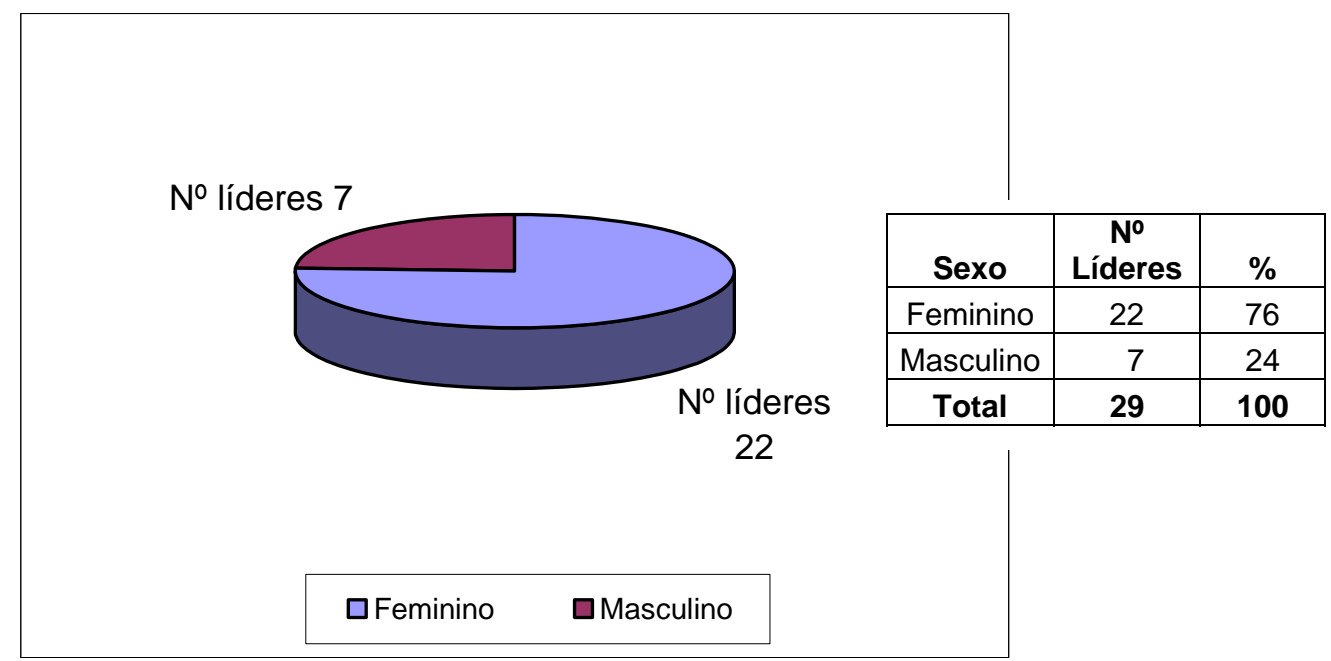

Verifica-se que 76\% (22) da amostra de líderes são do sexo feminino e que 24\% (7) são do sexo masculino. Pode-se observar a predominância de mulheres trabalhando no hospital, bem como sua posição de liderança destacada nos cargos que ocupa ou nos papéis desempenhados em programas e projetos administrativos, nos dia de hoje. 


\subsubsection{Quanto ao tempo na instituição}

Gráfico 3 - Caracterização das lideranças quanto ao tempo na instituição

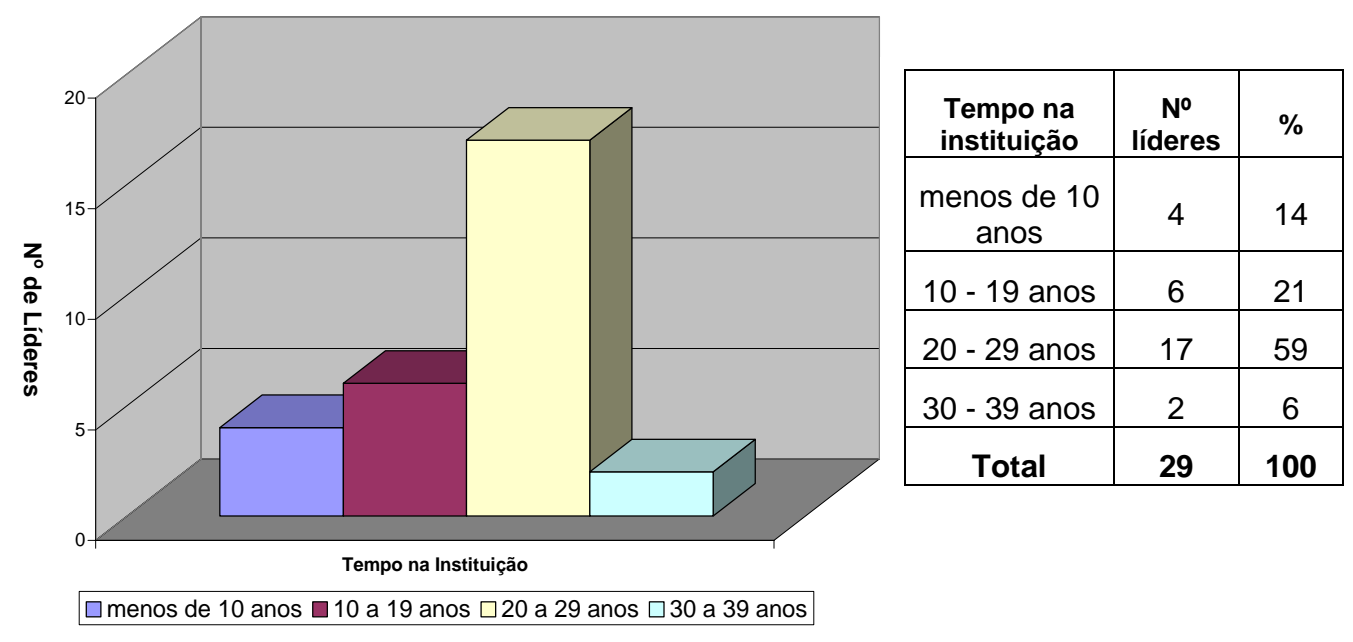

Verifica-se que 59\% (17) das lideranças têm de 20 a 29 anos de instituição. Sendo uma instituição hospitalar complexa voltada à assistência, ao ensino e à pesquisa, o aumento no tempo de casa leva os profissionais líderes a adquirirem uma expertise naquilo que fazem, caracterizando uma competência técnica de excelência, além de conhecerem mais a cultura organizacional, direcionando o desenvolvimento de atitudes que agreguem aos processos principais de trabalho e terem maior segurança em lidar com os processos de gestão de pessoas como é o caso da avaliação de desempenho. 


\subsubsection{Quanto à profissão}

Gráfico 4 - Caracterização das lideranças quanto à profissão

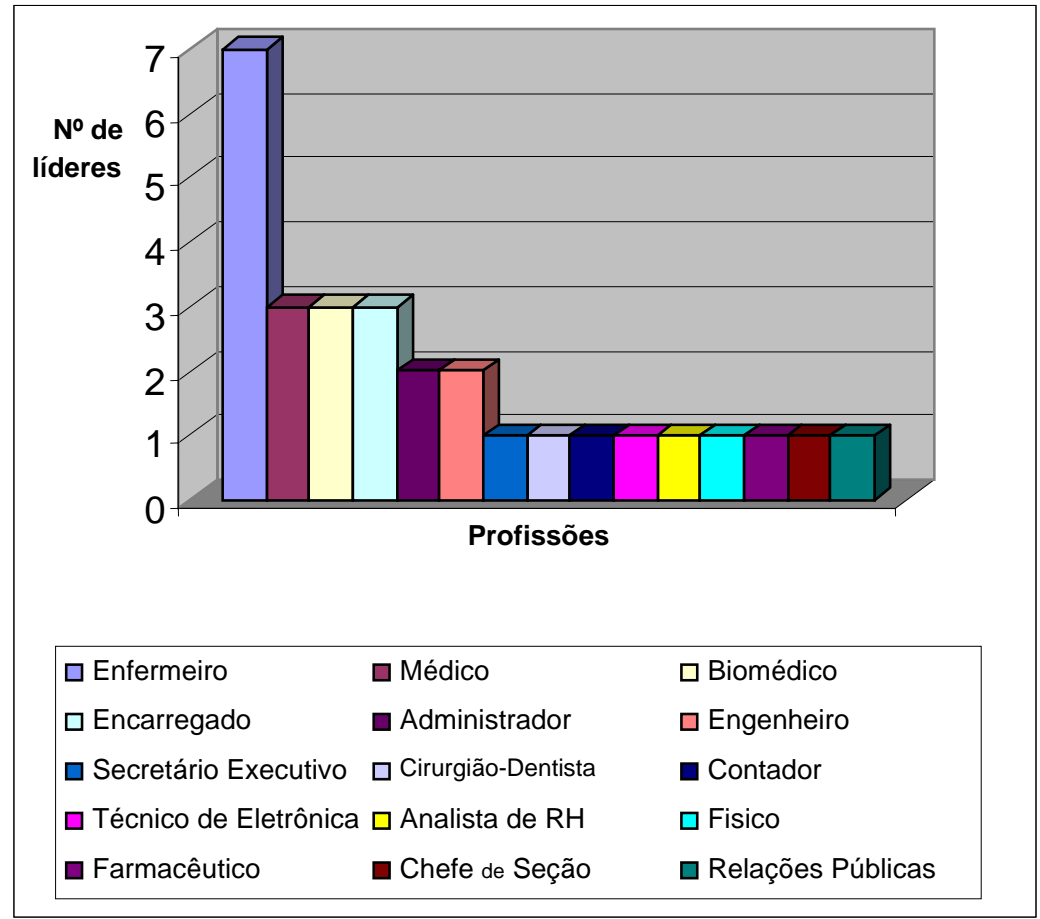

\begin{tabular}{|l|c|c|}
\hline \multicolumn{1}{|c|}{ Profissão } & $\mathbf{N}^{\circ}$ & $\%$ \\
\hline Enfermeiro & 7 & 24 \\
\hline Médico & 3 & 11 \\
\hline Biomédico & 3 & 11 \\
\hline Encarregado & 3 & 11 \\
\hline Administrador & 2 & 8 \\
\hline Engenheiro & 2 & 8 \\
\hline $\begin{array}{l}\text { Secretário } \\
\text { Executivo }\end{array}$ & 1 & 3 \\
\hline $\begin{array}{l}\text { Cirurgião- } \\
\text { Dentista }\end{array}$ & 1 & 3 \\
\hline Contador & 1 & 3 \\
\hline $\begin{array}{l}\text { Técnico de } \\
\text { Eletrônica }\end{array}$ & 1 & 3 \\
\hline $\begin{array}{l}\text { Analista de } \\
\text { RH }\end{array}$ & 1 & 3 \\
\hline Físico & 1 & 3 \\
\hline Farmacêutico & 1 & 3 \\
\hline $\begin{array}{l}\text { Chefe de } \\
\text { Seção }\end{array}$ & 1 & 3 \\
\hline $\begin{array}{l}\text { Relações } \\
\text { Públicas }\end{array}$ & 1 & 3 \\
\hline $\begin{array}{l}\text { Total } \\
\text { 29 }\end{array}$ & $\mathbf{1 0 0}$ \\
\hline
\end{tabular}

Observa-se que 24\% (7) das lideranças que participaram dos grupos são enfermeiros. O hospital tem como áreas assistenciais: ambulatório, emergência, terapias intensivas (adulto e infantil), unidades de internação (adulto e infantil), centro-cirúrgico e central de material esterilizado. Especificamente, o quadro funcional da enfermagem é atuante 24 horas ininterruptas, perfaz o maior número de funcionários, necessitando de líderes que coordenem os processos de trabalho e que saibam lidar com as necessidades e expectativas dos membros da equipe. 


\subsubsection{Quanto ao nome do cargo}

Gráfico 5 - Caracterização das lideranças quanto ao nome do cargo

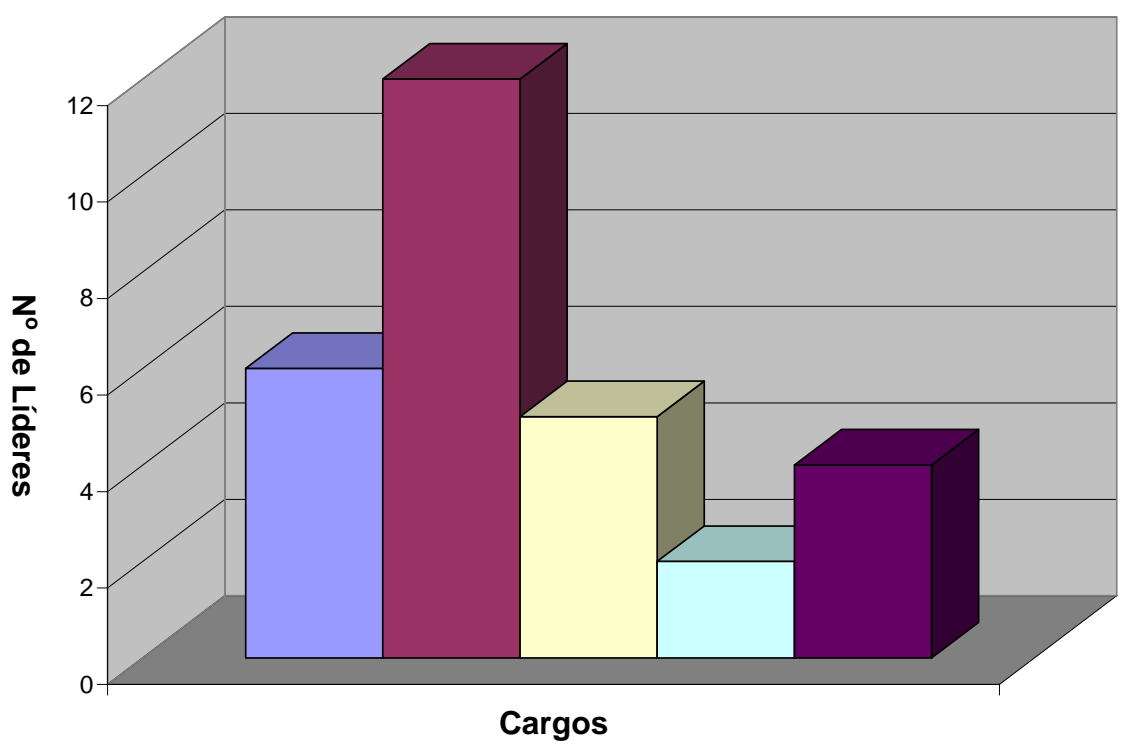

$\square$ Diretor $\square$ Chefe $\square$ Encarregado $\square$ Assistente $\square$ Liderenças Informais

\begin{tabular}{|c|c|c|}
\hline Nome do cargo & $\mathbf{n}^{\circ}$ líder & $\%$ \\
\hline Diretor & 6 & 21 \\
\hline Chefe & 12 & 41 \\
\hline Encarregado & 5 & 17 \\
\hline Assistente & 2 & 7 \\
\hline $\begin{array}{c}\text { Lideranças } \\
\text { Informais }\end{array}$ & 4 & 14 \\
\hline Total & $\mathbf{2 9}$ & $\mathbf{1 0 0}$ \\
\hline
\end{tabular}

No Gráfico 5, evidencia-se que 86\% (25) são lideranças que ocupam cargos formais na instituição como diretores, chefes, encarregados e assistentes, enquanto que 14\% (4) são líderes informais que, apesar de não possuírem cargos de chefias, são reconhecidos pela equipe e pelo hospital por suas competências gerenciais e técnicas, bem como a maneira de trabalhar com as pessoas incentivando o desenvolvimento e a coesão grupal. 
As lideranças, formais e informais, têm o desafio diário de administrar os processos de trabalho e as práticas relativas ao capital intelectual. Saber lidar com os conflitos no trabalho, aconselhar o funcionário para o desenvolvimento profissional e pessoal, descobrir talentos e potenciais em sua equipe, avaliar e acompanhar o progresso do desempenho do trabalhador são alguns exemplos das principais ações que caracterizam o papel do líder como gestor de pessoas.

\subsubsection{Quanto ao tempo no cargo}

Gráfico 6 - Caracterização das lideranças quanto ao tempo no cargo

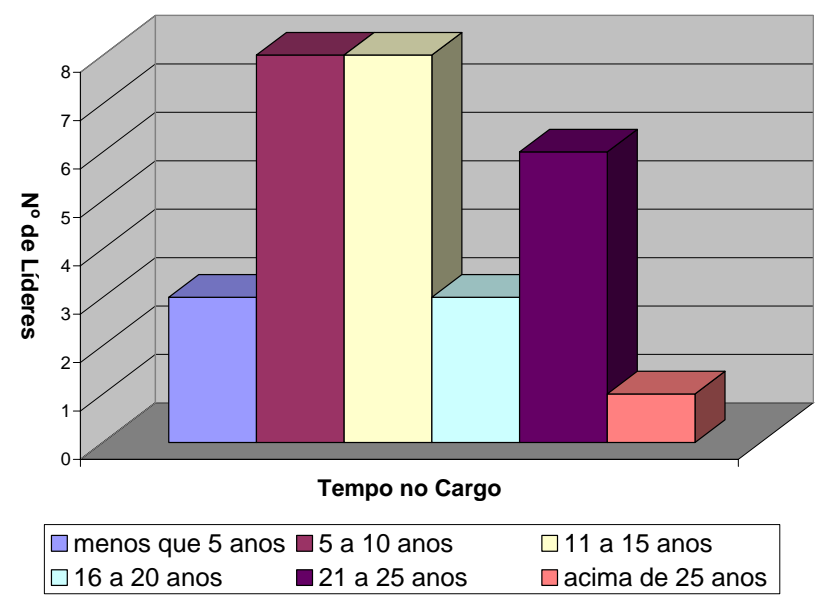

\begin{tabular}{|c|c|c|}
\hline $\begin{array}{c}\text { Tempo no cargo } \\
\text { atual }\end{array}$ & $\begin{array}{c}\mathbf{N}^{\circ} \\
\text { líderes }\end{array}$ & $\%$ \\
\hline menos que 5 anos & 3 & 10 \\
\hline 5 a 10 anos & 8 & 28 \\
\hline 11 a 15 anos & 8 & 28 \\
\hline 16 a 20 anos & 3 & 10 \\
\hline 21 a 25 anos & 6 & 21 \\
\hline acima de 25 anos & 1 & 3 \\
\hline Total & $\mathbf{2 9}$ & $\mathbf{1 0 0}$ \\
\hline
\end{tabular}

No Gráfico 6, observa-se que quanto ao tempo no cargo, 56\% (16) dos líderes participantes dos grupos oscilam de 5 a 15 anos. Uma instituição complexa, voltada à assistência, ao ensino e à pesquisa, necessita de líderes pró-ativos. O tempo procura fazer a liderança desenvolver importante visão dos aspectos técnicogerenciais e das ações direcionadas à orientação, ao aconselhamento e ao feedback da equipe de trabalho. Saber lidar com as pessoas constitui uma aprendizagem continuada, sendo um dos seus desafios. BERGAMINI (1983) enfatiza que “... é necessário ter recursos pessoais para planejamento e controle da produtividade dos outros, ou melhor, é preciso ser capaz de conseguir que os subordinados trabalhem por ele, em lugar de trabalhar dobrado”. 
Nesse grupo de líderes, observam-se pessoas com menos de 5 anos de atuação no cargo e pessoas acima de 25 anos. De um lado, pode-se dizer que há pessoas portadoras de habilidades, atitudes e experiências anteriores que refletem a postura da liderança. Suas competências apenas precisam de um contínuo aprimoramento para acompanhar as exigências do mercado. Por outro lado, as pessoas podem alcançar a posição administrativa como parte de uma carreira profissional. Apesar de tudo isso, são pessoas que apresentam uma dedicação significativa em relação ao seu trabalho técnico-gerencial e aos aspectos voltados às situações que envolvem gente.

\subsubsection{Quanto à jornada de trabalho}

Gráfico 7 - Caracterização das lideranças quanto à jornada de trabalho

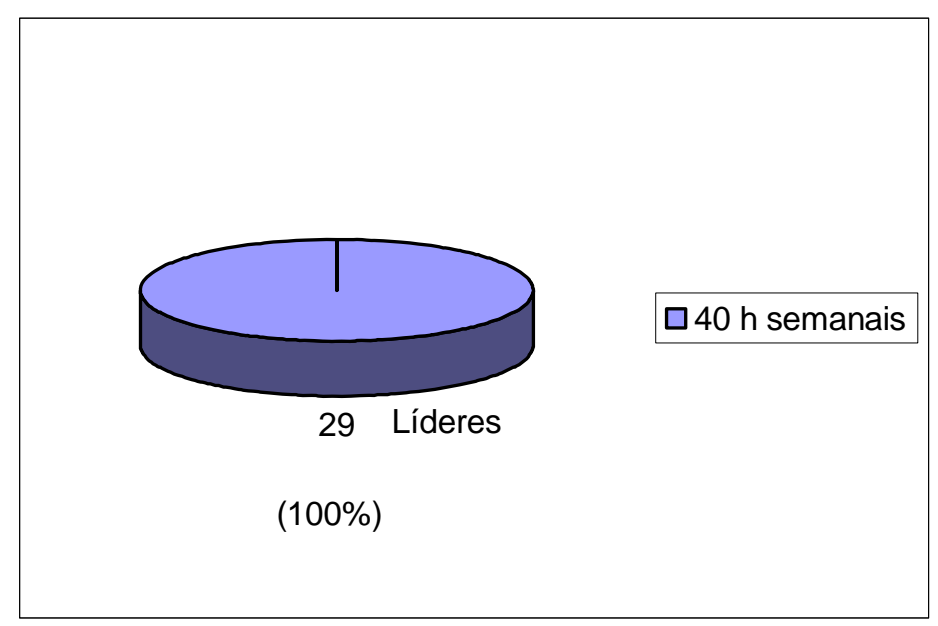

Observa-se que 100\% (29) da amostra de líderes cumprem uma jornada de 40 horas semanais, caracterizando a necessidade de dedicação exclusiva para desenvolver atividades técnico-gerenciais e atitudes de facilitador, orientador e avaliador de sua equipe de trabalho nas diversas demandas que compõem o cotidiano de um hospital. 


\subsubsection{Quanto ao número de funcionários sob sua responsabilidade}

Gráfico 8 - Caracterização das lideranças quanto ao número de funcionários sob sua responsabilidade

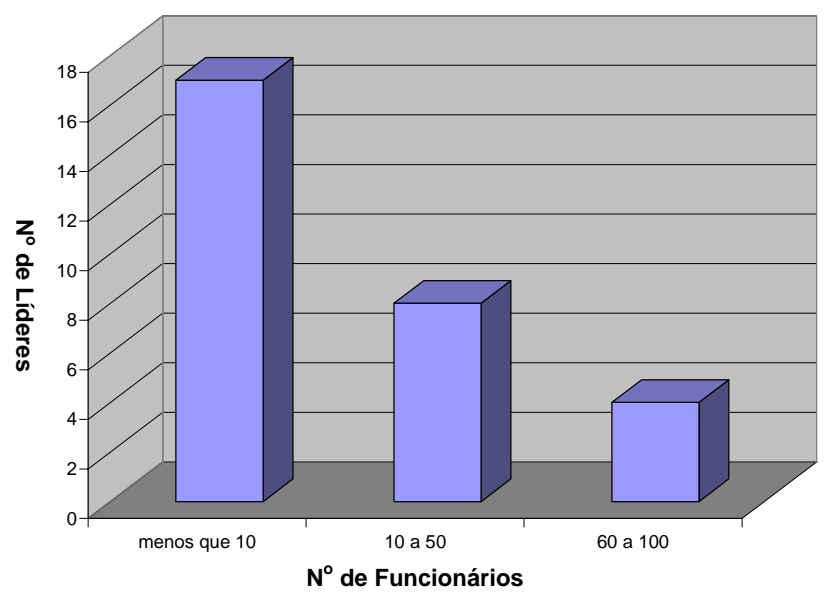

\begin{tabular}{|c|c|c|}
\hline $\begin{array}{c}\mathbf{N}^{\circ} \text { de } \\
\text { funcionários }\end{array}$ & $\begin{array}{c}\mathbf{N}^{\circ} \text { de } \\
\text { líderes }\end{array}$ & $\%$ \\
\hline $\begin{array}{c}\text { menos que } \\
10\end{array}$ & 17 & 59 \\
\hline 10 a 50 & 8 & 27 \\
\hline 60 a 100 & 4 & 14 \\
\hline Total & $\mathbf{2 9}$ & $\mathbf{1 0 0}$ \\
\hline
\end{tabular}

No Gráfico 8, quanto ao número de funcionários sob a responsabilidade do líder, observa-se que 59\% (17) dos líderes têm menos que 10 funcionários. Por outro lado, 14\% (4) apresentam de 60 a 100 colaboradores, a exemplo do serviço de farmácia e da coordenação de enfermagem.

O papel desempenhado pelo líder está mais focado na sua habilidade de lidar com as pessoas para o bom desenvolvimento dos trabalhos diários. O fato de realizar uma gestão com 10 ou 100 funcionários vai depender de sua capacidade de gerenciar os processos de trabalho, buscando o comprometimento dos seus colaboradores. 


\section{$7.22^{\mathrm{a}}$ PARTE - ANÁLISE DO PROCESSO DE AVALIAÇÃO DE DESEMPENHO}

As reuniões dos grupos focais seguiram um guia de discussão com sete questões semi-estruturadas lançadas pela pesquisadora aos participantes:

a) O que vocês esperam de uma avaliação? (mapear expectativas).

b) Como foi a avaliação de vocês? Como vocês se sentiram durante o processo? (mapear a realidade e os sentimentos presentes).

c) Do que vocês gostaram e não gostaram quando foram avaliados? (mapear sentimentos).

d) O que vocês acham mais importante avaliar em seus colaboradores?

e) Quando vocês precisam avaliar alguém, como vocês fazem? E o que os motiva? (mapear atitudes)

f) Quais são os atributos mais significativos a serem avaliados em um líder? (competência dos líderes)

g) Suponhamos que não houvesse nenhum formulário de avaliação e vocês tivessem que criar um. Quais informações vocês colocariam? E, como apresentariam os resultados finais da avaliação? (contribuições)

As questões a serem respondidas tinham como objetivos explorar aspectos subjetivos voltados às expectativas, sentimentos e atitudes dos líderes frente ao processo de avaliação e, também, trazer contribuições importantes revelando sua eficiência. Foi imprescindível a manifestação de todos os membros dos grupos para o alcance dos objetivos. 
As análises de conteúdo das manifestações dos líderes sobre o processo de avaliação de desempenho permitiram estruturar cinco categorias:

1. Expectativa dos líderes em relação ao processo de avaliação;

2. Sentimentos manifestados;

3. Atributos (competências) da força de trabalho e dos líderes;

4. Atitudes dos líderes evidenciadas;

5. Contribuições para a eficiência da avaliação.

As 5 categorias serão apresentadas individualmente, a seguir:

\section{Expectativa dos líderes em relação ao processo de avaliação}

Quanto à expectativa dos líderes sobre o processo de avaliação, conforme Quadro 4, foi revelada a necessidade de ser objetivo, claro e tranqüilo, possibilitando levantar os pontos fortes e os aspectos a serem melhorados no desempenho do trabalhador.

\section{Quadro 4 - Expectativas dos líderes sobre o processo de avaliação}

\section{O QUE VOCÊS ESPERAM DE UMA AVALIAÇÃO? (EXPECTATIVAS)}

\begin{tabular}{|c|c|c|}
\hline $\begin{array}{c}\text { Sujeitos } \\
\text { da } \\
\text { pesquisa } \\
\text { (SP) }\end{array}$ & Manifestações & Idéias principais \\
\hline SP1 & $\begin{array}{l}\text {... seja clara e não coerciva. Que as pessoas } \\
\text { tenham a liberdade e a tranqüilidade de expor } \\
\text { seus pontos. } \\
\text {...identificar os pontos fortes e fracos destes } \\
\text { profissionais que estão sendo avaliados e que } \\
\text { estes pontos fracos sejam trabalhados como } \\
\text { melhoria de atuação deles na área ... } \\
\text {...existe uma avaliação de três meses e depois de } \\
\text { nove meses, depois acabou. Neste tempo, o } \\
\text { funcionário mostra-se cooperativo, age com as } \\
\text { normas e deveres da instituição e de repente ele } \\
\text { começa a ficar um funcionário relapso. }\end{array}$ & $\begin{array}{l}\text { Ser clara e não coercitiva. } \\
\text { Identificar os pontos fortes } \\
\text { e fracos. } \\
\text { Ser mais objetiva e menos } \\
\text { subjetiva. } \\
\text { Identificar para o } \\
\text { funcionário os pontos a } \\
\text { serem desenvolvidos. }\end{array}$ \\
\hline
\end{tabular}




\section{O QUE VOCÊS ESPERAM DE UMA AVALIAÇÃO? (EXPECTATIVAS)}

(Continuação)

\begin{tabular}{|c|c|}
\hline SP & Manifestações \\
\hline P1 & $\begin{array}{l}\text { Avaliação que não seja só da competência, mas } \\
\text { também da avaliação do emocional, porque às vezes } \\
\text { a pessoa é competente, mas não tem a inteligência } \\
\text { emocional suficiente. Eu acho que têm que ser } \\
\text { avaliado duas coisas: competência e o emocional. }\end{array}$ \\
\hline
\end{tabular}

... as avaliações são feitas e a gente não sabe para que serviu aquele instrumento. A gente responde, sabe todos os quesitos que estão na avaliação e a gente não sabe o que foi feito com aquele material que foi trabalhado.

SP2 $\quad$... que a avaliação se encaminhe mais para o lado objetivo e não subjetivo.

SP3 $\quad$... poder identificar tantos pontos fortes, ... pontos a
serem desenvolvidos e oportunidades de melhorias.

Acho que uma avaliação sem uma perspectiva de futuro é vã. Ela tem que dar subsídio para você programar o futuro, corrigir o que está errado, programar aquilo que você tem potencial de aprendizado ou que a instituição precisa ...

SP4 A avaliação ser clara, objetiva, ...que elenque vários pontos não só negativos, mas os positivos.

Ter um Feedback é fundamental... Aquela avaliação $360^{\circ}$.

Eu acho que é uma prioridade realmente ter um plano de carreira. Porque não adianta você avaliar e aquilo ficar perdido. Tem que ter um planejamento, um plano de carreira e não adianta a gente motivar o funcionário ... Avaliação com caráter de desenvolvimento e promoção.

SP5 ... na elaboração da avaliação precisa ver direito quais são os objetivos, o que se pretende... Então, em cima disso, elaborar o que se pretende na realização da avaliação.

... a questão do estresse que é causado, quando uma pessoa fala "vou ser avaliada", tem gente que acende uma vela, treme as pernas, várias reações acontece. ... seja de tal forma que o avaliado se sinta à vontade e o avaliador tenha a competência para Idéias principais

Ser prática construtiva evidenciando aspectos críticos.

Ser mecanismo de reconhecimento do profissional e não de punição.

Gerar clima receptivo e de aprendizagem e não estresse.

Ter padrão sistemático de realização. Ser prática, contínua, dinâmica e com acompanhamento dos aspectos a serem melhorados.

Conhecer os objetivos da avaliação e aplicar com seriedade.

Estar vinculada a plano de desenvolvimento do funcionário, a planos de carreira e a uma política coerente de gestão de pessoas.

Ter importante abrangência envolvendo no processo de avaliação todas as partes que afetam e que são afetadas (Stakeholders), gerando uma avaliação $360^{\circ}$.

Avaliar as competências emocional e técnica.

Propiciar feedback mostrando ser um processo confiável, sério, sigiloso e seguro. 


\section{O QUE VOCÊS ESPERAM DE UMA AVALIAÇÃO? (EXPECTATIVAS)}

(Continuação)

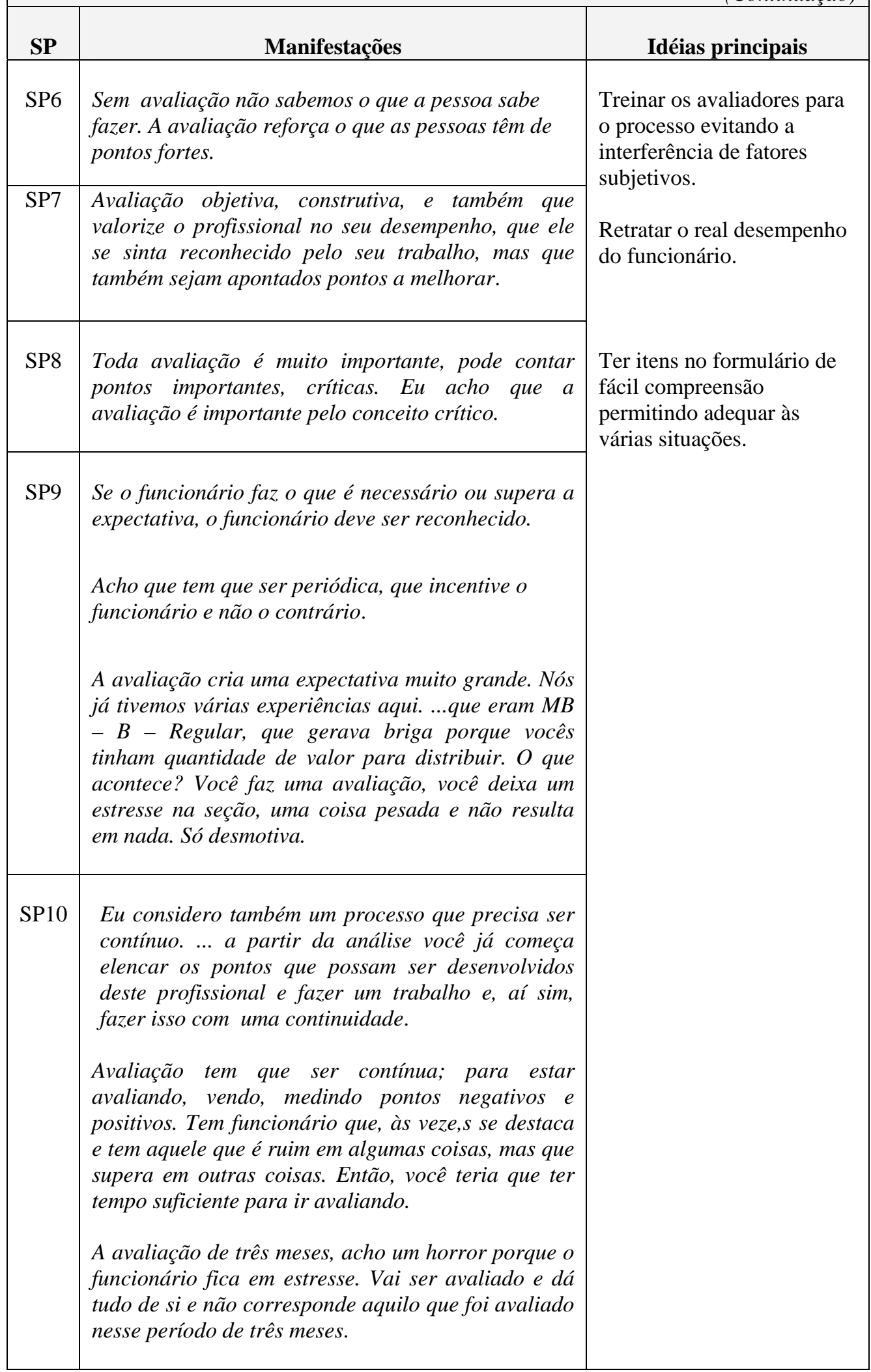




\section{O QUE VOCÊS ESPERAM DE UMA AVALIAÇÃO? (EXPECTATIVAS)}

(Continuação)

\begin{tabular}{|c|c|c|}
\hline SP & Manifestações & Idéias principais \\
\hline SP11 & $\begin{array}{l}\text {...Um processo dinâmico, não estático. Não pode } \\
\text { ser uma coisa pontual... Periodicidade, ...tem que } \\
\text { seguir um padrão. Faço uma nova avaliação em } \\
\text { cima daquilo que foi sugerido como melhoria. Tem } \\
\text { que ter um modelo inicial para ser seguido. Vamos } \\
\text { trabalhar nos pontos negativos, vamos reavaliar } e \\
\text { acompanhar o restante... }\end{array}$ & \\
\hline SP12 & $\begin{array}{l}\text { Eu, junto com a minha equipe, criamos uma espécie } \\
\text { de "Follow-up" onde os pontos relevantes e } \\
\text { detalhes são pontuados ao longo do período. }\end{array}$ & \\
\hline SP13 & $\begin{array}{l}\text {...acho que a avaliação é um processo contínuo, } \\
\text { precisa existir um padrão. Deve ter um jeito para } \\
\text { controlar por ano, semestral, período, os } \\
\text { comportamentos, o que é bom ou não foi bom para a } \\
\text { pessoa. Avaliação deve ser praticamente constante, } \\
\text { um feedback constante. } \\
\text { Na avaliação de desempenho espera-se que a pessoa } \\
\text { atinja o nível de desempenho que se espera dela, } \\
\text { dentro daquele cargo que ela ocupa. A partir daí, } \\
\text { ela vai conseguindo posições em níveis hierárquicos } \\
\text { superiores ..., construindo sua carreira ... Se pensar } \\
\text { em termos da organização, vai parecer que a } \\
\text { avaliação é uma ferramenta que não tem utilidade } \\
\text { porque não sabemos o que fazer com o resultado em } \\
\text { termos de promoção e faixa salarial. Se pensar que } \\
\text { é uma ferramenta para o desenvolvimento é uma } \\
\text { coisa importante. } \\
\text { Às vezes, a avaliação fica uma ferramenta estranha, } \\
\text { estressante, porque quem está avaliando nem } \\
\text { sempre sabe o que esperar da avaliação e o } \\
\text { avaliado não sabe qual é o nível de desempenho que } \\
\text { se espera dele. }\end{array}$ & \\
\hline SP14 & $\begin{array}{l}\text {...o feedback no trabalho tem que acontecer todo o } \\
\text { dia....Tem que elogiar no momento correto, chamar } \\
\text { atenção no momento certo, não dá para deixar para } \\
\text { depois, para a hora da avaliação. } \\
\text { Que ela resulte em mudanças. Que seja realmente } \\
\text { uma ferramenta fiel, medir aquilo que você propõe a } \\
\text { avaliar, o desempenho. }\end{array}$ & \\
\hline
\end{tabular}




\section{O QUE VOCÊS ESPERAM DE UMA AVALIAÇÃO? (EXPECTATIVAS)}

(Continuação)

\begin{tabular}{|c|c|c|}
\hline SP & Manifestações & Idéias principais \\
\hline SP15 & $\begin{array}{l}\text {... a própria chefia também está sujeita a avaliação, } \\
\text { para que possa ter uma inter-relação de } \\
\text { informações para uma consistência de resultados. } \\
\text {...não só na avaliação, para ver desempenho. Para } \\
\text { você treinar o funcionário, falar das dificuldades } \\
\text { dele para a melhoria do serviço. Também ter } \\
\text { alguma coisa para incentivar como montar um } \\
\text { plano de carreira ou mérito dos funcionários que } \\
\text { mereçam. }\end{array}$ & \\
\hline SP16 & $\begin{array}{l}\text { Que a avaliação possa auxiliar outras pessoas; seja } \\
\text { alguma coisa real, palpável no sentido de você } \\
\text { poder depois implementar essas avaliações, porque } \\
\text { não adianta só avaliar e depois nada acontecer. É } \\
\text { importante fazer avaliação e depois que isso } \\
\text { transforme em atitude. }\end{array}$ & \\
\hline SP17 & $\begin{array}{l}\text { Acho que ela deve ser justa e trazer um Feedback } \\
\text { tanto para o avaliador quanto para o avaliado. }\end{array}$ & \\
\hline SP18 & $\begin{array}{l}\text { Espero que no final do processo você possa ter um } \\
\text { resumo da situação, um retrato da situação não só } \\
\text { do indivíduo como também do grupo como um todo. }\end{array}$ & \\
\hline SP19 & $\begin{array}{l}\text {... o maior problema é o nosso despreparo. Nós, na } \\
\text { verdade, não estamos devidamente preparados para } \\
\text { as análises. Eu espero que aquele que me avalie } \\
\text { possa querer encontrar pontos negativos, mas existe } \\
\text { sempre uma expectativa minha que consiga também } \\
\text { ver os pontos positivos. }\end{array}$ & \\
\hline SP20 & $\begin{array}{l}\text { Pode trazer tanto benefício para a pessoa que está } \\
\text { sendo avaliada como trazer prejuízo dependendo da } \\
\text { avaliação que é dada. Se realizada com critério e } \\
\text { honestidade acho que vai trazer benefícios, se ela é } \\
\text { feita com critérios injustos você vai cometer uma } \\
\text { injustiça. Vai trazer malefícios para a pessoa. }\end{array}$ & \\
\hline SP21 & $\begin{array}{l}\text { Quando a pessoa está sendo avaliada, quem está } \\
\text { avaliando tem que ser muito sincero em questões } \\
\text { muito complicadas. Por exemplo, alguns têm falado } \\
\text { sobre vestimenta, higiene, ... são critérios pesados. } \\
\text { Quem está avaliando deve saber usar as palavras } \\
\text { para não ofender quem está sendo avaliado. }\end{array}$ & \\
\hline
\end{tabular}




\section{O QUE VOCÊS ESPERAM DE UMA AVALIAÇÃO? (EXPECTATIVAS)}

(Continuação)

\begin{tabular}{|c|l|c|}
\hline SP & \multicolumn{1}{|c|}{ Manifestaçães } & Idéias principais \\
\hline SP22 & $\begin{array}{l}\text { Eu acho que a avaliação sempre pode ter alguma } \\
\text { coisa positiva, mas pela história, eu só vi pontos } \\
\text { negativos. Primeiro, gera conflitos; segundo não é } \\
\text { sigilosa. Porque você conversa com colegas, fala } \\
\text { como foi, quanto tirou. Sinceramente isso é horrível. } \\
\text {.. Nós não estamos preparados para avaliar. ... Em } \\
\text { função disso se cria um estresse, um tormento na } \\
\text { casa. O que representa a avaliação?... É ferramenta } \\
\text { inútil. }\end{array}$ \\
\hline SP23 & $\begin{array}{l}\text { muitas vezes você não consegue adequar o avaliado } \\
\text { dentro daquela situação. ... É injusto com o o } \\
\text { funcionário porque não encontro o item certo para } \\
\text { aplicar. Lidamos com pessoas. É complicado e e } \\
\text { difícil. Cada um é cada um. Fica muito complicado. } \\
\text { Muito difícil a avaliação. }\end{array}$ \\
\hline
\end{tabular}

Toda avaliação de desempenho pressupõe cuidados em sua preparação, execução e interpretação. A compreensão da sua finalidade direciona a elaboração e aplicabilidade de forma eficaz.

O sistema de avaliação de desempenho precisa ter como características: ser simples, estabelecendo um ponto de distinção entre os funcionários que estão acima e abaixo da performance normal; ter uma função totalmente distinta de outros processos administrativos; limitar a coleta de informações avaliativas destacando a opinião do chefe se o desempenho está acima ou abaixo do aceitável no passado e a estimativa do chefe quanto às possibilidades futuras e ser participativo, enfatizando a importância do processo de comunicação com o envolvimento do avaliador e do avaliado.

Como instrumento de diagnóstico bem empregado dentro das organizações, a avaliação representa uma medida útil e salutar para todos, gerando análise objetiva e sintética do desempenho humano, constituindo aos líderes importante ferramenta de gestão na atividade de conduzir pessoas (BERGAMINI, 1983). 
Além dessa objetividade e clareza, foram ressaltados os aspectos construtivos e críticos e não punitivos da avaliação que precisa identificar o potencial do funcionário, valorizar e reconhecer seu trabalho.

O processo de avaliação é o retrato fiel do comportamento de cada pessoa em situação de trabalho, atendendo as diferentes expectativas da organização, do avaliador e do avaliado sendo, assim, destacadas por BERGAMINI (1983):

“À empresa em si, que, conhecendo melhor seus insumos humanos, poderá conseguir maior produtividade dos mesmos, buscando melhores níveis de satisfação ao detectar problemas que estejam dificultando ou impedindo a utilização desses mesmos insumos.

Ao avaliador que, (...) não somente reafirmará sua autoridade sendo justo e avaliando com segurança, mas também poderá rever a validade da sua técnica de chefia, uma vez que entenda ser a conduta dos seus subordinados o reflexo da forma pela qual exerce seu papel de chefia;

Ao avaliado que, (...) está preocupado com a própria produtividade e, consequentemente, em saber como se está saindo. Conhecendo ele a importância de seus pontos positivos e as dificuldades que ocasionam seus pontos negativos; sabendo que pode contar com supervisor e a empresa no sentido de melhor aproveitar os primeiros e suprimir os segundos, sentira maior segurança e ânimo para uma vida de trabalho orientada à autorealização e à utilização tão integral quanto possível de suas potencialidades” (p.28).

Fica demonstrada a importante aplicação de um processo de avaliação principalmente quando ele é compreendido como um sistema que gera repercussões na própria dinâmica organizacional e, conseqüentemente, na produtividade, na melhoria da conduta do líder por meio de auto-feedback e no desenvolvimento do profissional que se torna mais ciente do seu trabalho e do seu potencial, gerando segurança e motivação.

Outro aspecto importante destacado pelos grupos de líderes foi que a prática da avaliação precisa ser contínua, dinâmica e monitorada. Ter um padrão sistemático de realização vinculado a planos de desenvolvimento para cada 
funcionário, possibilitando o acompanhamento, no tempo, das melhorias do desempenho, previamente discutidas entre o avaliador e o avaliado.

A necessidade de avaliar os profissionais, periódica e sistematicamente, surge do fato de que todas as pessoas são diferentes e, portanto, apresentam formas distintas de lidarem com as atividades e atingirem as metas organizacionais.

É preciso caracterizar muito bem as diferenças individuais, pois ao lidar de forma eficaz com a avaliação, o líder possa obter um clima de maior satisfação no trabalho gerando melhores resultados.

A avaliação de desempenho deve ser realizada sempre de forma sistemática, com intervalos de tempos iguais, a fim de que seja possível comparar a evolução ou involução da pessoa no trabalho. Existem cuidados especiais na determinação da freqüência da avaliação. BERGAMINI (1983) menciona três critérios básicos que norteiam a escolha dos intervalos de tempo para a repetição da avaliação:

1. Jurídico: informa períodos de avaliação que decidirá se determinadas pessoas continuam ou não no quadro funcional da organização. É destacado o período de experiência (noventa dias) que avalia o desempenho do trabalhador por ocasião de sua efetivação.

2. Trabalho: informa a freqüência da avaliação inversamente proporcional a complexidade do trabalho, ou seja, quanto menos complexo for o trabalho, mais vezes se devem repetir a avaliação do trabalhador e, quanto mais complexo for menos freqüentes serão as épocas de avaliação.

3. Política de pessoal: informa no mínimo duas avaliações para que sejam determinadas ações consistentes como aumentos, promoções, transferências e desligamentos.

Para ser um processo construtivo e que alcance os resultados esperados, a abrangência é essencial. Ampliar o contingente de avaliadores, gerando uma Avaliação $360^{\circ}$, onde além da chefia e do próprio funcionário, clientes, pares 
e outras partes interessadas (Stakeholders) estejam envolvidos no processo de avaliação.

A seriedade de toda avaliação está ligada à existência de políticas coerentes de gestão de pessoas. Os grupos enfatizaram a necessidade da existência de planos de carreira atrelados a esse processo de avaliação para gerar motivação do profissional.

A competência emocional, além da competência técnica, foi manifestada como item crucial para ser avaliado. As pessoas diferem umas das outras em vários fatores como na constituição física, na personalidade e na inteligência. O modo de lidar com as emoções também constitui um diferencial importante em cada pessoa e que muito tem a ver com a vivência de cada um, assim como com a educação recebida.

São evidências de que as ações são desencadeadas por emoções. Quando a pessoa se sente afetivamente atraída por seu trabalho, ela apresenta, em geral, maiores níveis de desempenho. Aquele que reconhece em seu trabalho uma situação contrária (negativa) terá maior tendência em decair sua produtividade e piorar seu desempenho.

Segundo os líderes, para que a avaliação possa ser construtiva, contínua e geradora de resultados, o avaliado e a equipe precisam receber feedback do processo realizado, garantindo confiança, seriedade e segurança do mesmo na instituição.

Relevante é o treinamento dos avaliadores, para que sejam fidedignos os resultados obtidos, sendo as pessoas avaliadas realmente de acordo com os critérios estabelecidos no processo, não havendo a interferência de fatores pessoais e subjetivos que possam tornar os dados da avaliação inconsistentes.

Foi comentado o cuidado com as palavras que devem ser bem conduzidas para atingir o objetivo, sem ofender quem está sendo avaliado. 
Ao preparar os avaliadores deve-se deixar bem claro que as informações do profissional avaliado são referentes a um passado próximo, e não a um passado distante nem a um futuro incerto, apesar de muitos avaliadores terem a tendência de se prenderem a dados muito antigos ou ainda a esperança de futuras modificações de comportamento (BERGAMINI, 1983).

O pressuposto fundamental de um processo avaliativo é de que só é possível avaliar uma pessoa a partir do que ela produziu. A avaliação é um retrato, uma imagem fiel possível e aproximada do comportamento do profissional em uma situação de trabalho.

O despreparo dos avaliadores compromete seriamente a validade dos dados com os quais se está trabalhando, o que dificulta o alcance dos objetivos e compromete a política de pessoas a ser adotada internamente pela organização.

Tal despreparo pode ser decorrente de dois aspectos distintos: a falta de requisitos necessários ao cargo, tornando-o incapaz de discriminar e de retratar as diferenças individuais de comportamento de seus funcionários e, a não transmissão de todo o conhecimento necessário, mesmo tendo os requisitos exigidos pelo cargo. Apesar disso, todos os líderes devem ser submetidos ao treinamento de avaliadores, iniciando um processo paulatino de substituição daqueles que não apresentam a referida competência.

O estresse presente na época da avaliação foi manifestado pelo grupo como um fator que pode dificultar a condução do processo. O preparo e o conhecimento do avaliador podem desencadear diversas emoções e reações. “As emoções são reações fisiológicas e psicológicas que influem na percepção, aprendizagem e no desempenho” (BERGAMINI, 1983, p.70).

Uma das características individuais do avaliador é sua maturidade afetiva e emocional diminuindo a subjetividade ou alguma distorção durante a 
avaliação. Saber lidar com emoções constitui passo fundamental para avaliar a pessoa com isenção de ânimo e orientação precisa.

Avaliadores despreparados estarão cumprindo apenas mais uma tarefa e gerando sentimentos nos avaliados que podem desmotivá-los. Sendo uma prática construtiva vinculada a uma diretriz institucional, o avaliador deve se comprometer em gerar um ambiente confiante voltado ao desenvolvimento profissional e pessoal.

Além das informações mencionadas acima, a última expectativa manifestada pelos grupos foi quanto ao instrumento de avaliação que precisa fotografar o real desempenho do funcionário. Muitas vezes, as questões podem tornar difícil a avaliação, gerando conflitos tanto para o avaliador como para o avaliado.

\section{Sentimentos manifestados}

No decorrer dos anos, houve nesse hospital a aplicação de vários instrumentos de avaliação com resultados pouco satisfatórios. Mais da metade do número de líderes que participaram dos grupos é constituído por profissionais que atuaram no hospital há mais de 20 anos e que passaram por tais processos de avaliação. Durante as discussões, observou-se que, para a maioria, a avaliação não agregou valor na época, gerando descrença, constrangimentos, insatisfações e sentimentos negativos. Para alguns líderes do estudo, o processo de avaliação foi justo, respeitoso, sério e sigiloso, gerando satisfação e desenvolvimento profissional, trazendo sentimentos positivos, como evidenciados por meio das manifestações apresentadas no Quadro 5. 


\section{Quadro 5 - Manifestações de satisfação e de insatisfação dos líderes sobre o processo de avaliação}

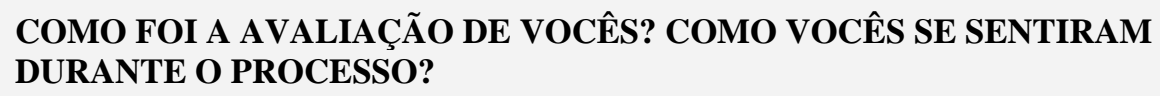

\begin{tabular}{|c|c|c|}
\hline $\begin{array}{c}\text { Sujeitos } \\
\text { da } \\
\text { Pesquisa } \\
\text { (SP) }\end{array}$ & Manifestações & Idéias Principais \\
\hline SP1 & $\begin{array}{l}\text { A chefia fazia avaliação, inclusive explicava item por } \\
\text { item e esta avaliação era encarada por nós } \\
\text { funcionários como uma coisa importante. }\end{array}$ & $\begin{array}{c}\text { Manifestações de } \\
\text { satisfação: }\end{array}$ \\
\hline
\end{tabular}

A avaliação era uma coisa esperada e respeitosa, porque a chefia conduzia isso de uma forma e criava não uma coisa boba, não era nada disso, em todos os anos, era uma coisa boa ... e era uma coisa sigilosa. ... minha chefia colaborou bastante para o que eu sou hoje, ... , tenho certeza de que com a avaliação $e$ colocação dela consegui alguma coisa.

SP8 $\quad$ Fui avaliada muitas vezes por uma pessoa muito séria. Pontos positivos e negativos foram destacados que procurei corrigir. Pegou no lado profissional. Senti normal, sem problemas. Nada de traumático.

Entre meus funcionários, cada um procurava fazer uma avaliação muito honesta. Então não havia muitas mudanças ...

O diretor do serviço fazia a minha avaliação direta solicitando para eu me auto-avaliar. Em 100\% das vezes ele nunca modificou minha auto-avaliação.

...Havia Feedback quando eu tinha oportunidade de sentar com o meu subordinado e conversar ...

SP9 $\quad$ Fui avaliada muitas vezes. Não é muito bom ser avaliado, mas foi tranqüilo. Teve contato direto. Tem problemas que a gente resolve na hora. Foi normal. Não estressante.

SP10 Acho que todas as avaliações que eu tive foram justas ... me senti bem. Você se avaliava e depois se submetia a uma apreciação do chefe que verificava ponto por ponto e encerrava com o consenso.

- Avaliação como prática boa, esperada pelos funcionários, sigilosa e respeitosa.

- Contribui para o desenvolvimento profissional.

- Presença de feedback e de trocas.

- Ausência de estresse.

- Justa, com as etapas da auto-avaliação, avaliação da chefia e o consenso.

- Processo necessário nas organizações. 


\section{COMO FOI A AVALIAÇÃO DE VOCÊS? COMO VOCÊS SE SENTIRAM DURANTE O PROCESSO?}

(Continuação)

\begin{tabular}{|c|c|c|}
\hline SP & Manifestações & Idéias Principais \\
\hline SP17 & $\begin{array}{l}\text { No momento em que você não tem espaço para falar } \\
\text { fica muito difícil, fica uma relação unilateral, você } \\
\text { não consegue expor os problemas da área. } \\
\text { A partir desse momento, que você tem essa } \\
\text { oportunidade, você consegue a troca, o Feedback, eu } \\
\text { acho que fica muito mais interessante. }\end{array}$ & \\
\hline SP20 & $\begin{array}{l}\text {... Entrei como simples funcionário. Hoje sou } \\
\text { encarregado de setor aqui neste hospital. Foi muito } \\
\text { bom. }\end{array}$ & \\
\hline SP26 & $\begin{array}{l}\text {... onde o avaliador não tem motivação o avaliado } \\
\text { menos ainda, não foi vendida a idéia; eu acho que se } \\
\text { é um processo contínuo, a motivação não precisa ser } \\
\text { nem estruturalmente financeira ...a partir do } \\
\text { momento em que eu sou avaliada e eu posso avaliar } \\
\text { a gente chega a um amadurecimento, ... é um } \\
\text { amadurecimento que vai caminhar. } \\
\text { Em algum momento as empresas vão saber que o } \\
\text { processo de avaliação é necessário. }\end{array}$ & \\
\hline SP2 & $\begin{array}{l}\text {... a tua chefia não vai mudar, você não vai mudar, } \\
\text { porque não houve uma discussão a respeito, não } \\
\text { houve uma continuidade, então foi um cumprimento } \\
\text { de dever ... } \\
\text {.. meu diretor fez avaliação, eu fiz e acabou. Nós } \\
\text { cumprimos o nosso dever. }\end{array}$ & $\begin{array}{l}\text { Manifestações de } \\
\text { Insatisfação: } \\
\text { - Não houve discussão. } \\
\text { - Não houve continuidade } \\
\text { do processo. Apenas } \\
\text { cumprimento do dever. }\end{array}$ \\
\hline SP4 & $\begin{array}{l}\text { Mas, em certas situaçães, a avaliação acaba sendo } \\
\text { subjetiva, porque você coloca os seus valores. Avaliar } \\
\text { é difícil, ninguém é preparado para avaliar nem na } \\
\text { graduação nem na pós-graduação. } \\
\text { É muito difícil avaliar porque você acaba conduzindo } \\
\text { por seus valores. }\end{array}$ & $\begin{array}{l}\text { - Tem caráter subjetivo, } \\
\text { pessoal e sem critérios. } \\
\\
\text { - Falta credibilidade do } \\
\text { processo de avaliação } \\
\text { quando são utilizados } \\
\text { conceitos (muito bom, } \\
\text { bom, regular) para } \\
\text { distribuição entre os } \\
\text { funcionários da área. }\end{array}$ \\
\hline
\end{tabular}




\begin{tabular}{|c|c|c|}
\hline \multicolumn{3}{|c|}{$\begin{array}{l}\text { COMO FOI A AVALIAÇÃO DE VOCÊS? COMO VOCÊS SE SENTIRAM } \\
\text { DURANTE O PROCESSO? }\end{array}$} \\
\hline SP & Manifestações & Idéias Principais \\
\hline SP9 & $\begin{array}{l}\text { Tem que ser uma avaliação onde não tem porcentagem } \\
\text { porque nesta avaliação tantas pessoas tinham que ser } \\
\text { muito bom, tantas pessoas tinham que ser bom e tantas } \\
\text { pessoas tinham que ser regular. } \\
\text { Então tudo que você taxa em uma porcentagem, não } \\
\text { dá credibilidade alguma. } \\
\text { É muito pessoal. Há situações não profissionais. }\end{array}$ & $\begin{array}{l}\text { - Constrangimentos no } \\
\text { momento do consenso. } \\
\text { - Falta de amadureci- } \\
\text { mento dos avaliadores } \\
\text { quanto ao processo e ao } \\
\text { despreparo para a utili- } \\
\text { zação do instrumento de } \\
\text { avaliação. }\end{array}$ \\
\hline SP10 & $\begin{array}{l}\text {... eu não acredito muito no consenso, porque você, às } \\
\text { vezes, se sentia até um pouco constrangida com o } \\
\text { chefe; ele tendo que concordar com pontos que não } \\
\text { concordava até para não deixar você sem jeito e você, } \\
\text { também, tendo que aceitar pontos que as vezes não } \\
\text { concordava. Eu discordo do consenso. }\end{array}$ & $\begin{array}{l}\text { - Falta acompanhamento } \\
\text { do processo de avalia- } \\
\text { ção. } \\
\text { - Cenário organizacional } \\
\text { não compatível com o } \\
\text { momento da avaliação } \\
\text { causando incomodo para } \\
\text { todos. }\end{array}$ \\
\hline SP11 & $\begin{array}{l}\text { Nível de estresse muito alto. Senti a falta de } \\
\text { continuidade, falta de amadurecimento do avaliador ... } \\
\text { não sabia usar bem a ferramenta adequada. Vai } \\
\text { pontualmente, é bastante complicado. Não vai num } \\
\text { processo continuado. }\end{array}$ & $\begin{array}{l}\text { - Sentimento de } \\
\text { inutilidade e injustiça. } \\
\text { Ser avaliado por pessoa } \\
\text { com quem não } \\
\text { trabalhou. }\end{array}$ \\
\hline SP12 & $\begin{array}{l}\text { Eu fui avaliada e me senti péssima, ... fiquei } \\
\text { constrangida na hora de responder, porque às vezes } \\
\text { não tem meio termo, ou você é péssima ou você é boa. } \\
\text { Então eu coloquei o modo como me considerava ... e } \\
\text { aí meu chefe foi contra tudo aquilo que eu escrevi. }\end{array}$ & \\
\hline SP13 & $\begin{array}{l}\text { Não tive problemas em ser avaliada.... } \\
\text { No hospital, apesar de conversar, de pontuar, não tem } \\
\text { acompanhamento ... }\end{array}$ & \\
\hline SP15 & $\begin{array}{l}\text {... na iniciativa privada eu já passei por um processo } \\
\text { de avaliação. Eu me senti muito mal e incomodado. } \\
\text { Isto é, o momento em que a empresa estava passando, } \\
\text {... diminuindo de tamanho e colocando vários nomes ... } \\
\text { reengenharia ... processo de motivação, de avaliação } \\
\ldots \text { nada compatível com a realidade. Cenário } \\
\text { totalmente inadequado. Foi um trabalho } \\
\text { absolutamente perdido e não levado a sério pelos } \\
\text { avaliados e pelos avaliadores, todos sabiam da } \\
\text { situação e cumpriam aquela formalidade... }\end{array}$ & \\
\hline
\end{tabular}




\section{COMO FOI A AVALIAÇÃO DE VOCÊS? COMO VOCÊS SE SENTIRAM DURANTE O PROCESSO?}

(Continuação)

\begin{tabular}{|c|c|c|}
\hline SP & Manifestações & Idéias Principais \\
\hline SP18 & $\begin{array}{l}\text { Na posição de avaliado sempre existe um grau de } \\
\text { constrangimento ... }\end{array}$ & \\
\hline SP19 & Eu me senti um inútil. & \\
\hline SP21 & $\begin{array}{l}\text {... fiquei muito constrangida na primeira avaliação } \\
\text {... Eu não concordo com algumas avaliações porque } \\
\text { são muito taxativas, ou ele é ou não é. Às vezes, } \\
\text { depende de algum outro item ou observação de } \\
\text { quem está sendo avaliado, o porquê ele esteve assim } \\
\text { naquela época,... } \\
\text {... eu me senti muito constrangida. Também fiz } \\
\text { minha auto-avaliação e aí quando cheguei em meu } \\
\text { diretor ele discordou de todos os pontos. Mas não } \\
\text { explicou o porquêe o que ele queria de mim. }\end{array}$ & \\
\hline SP22 & $\begin{array}{l}\text { Sempre fui muito bem avaliada. Mas, não concordo } \\
\text { muito porque as pessoas levam pelo pessoal, não } \\
\text { tem critérios. }\end{array}$ & \\
\hline SP23 & $\begin{array}{l}\text {... Algumas vezes fui avaliada por pessoas que não } \\
\text { trabalhavam comigo no dia-a-dia. É muito } \\
\text { desagradável. Você se sente injustiçada. Senti-me } \\
\text { inútil. Só coisa ruimé destacada ... }\end{array}$ & \\
\hline SP24 & $\begin{array}{l}\text {... me senti constrangida ao fazer a auto-avaliação... } \\
\text {... era frustrante porque eu achava que ele iria ler e } \\
\text { iria dizer "eu discordo de você por alguma coisa", } \\
\text { mas ele perguntava "onde eu assino?" Nunca eu } \\
\text { tive um feedback. }\end{array}$ & \\
\hline SP25 & $\begin{array}{l}\text {... as avaliações feitas há } 15 \text { ou } 20 \text { anos atrás tinham } \\
\text { o mérito ... Há cada dois anos, cada avaliação tinha } \\
\text { uma contagem de pontos, e você tinha um aumento } \\
\text { de salário de } 5 \text { a } 7 \% \text {. Isso acabou não existe mais. }\end{array}$ & \\
\hline
\end{tabular}


O avaliador é a pessoa que está direta ou indiretamente envolvida na atividade de verificar as diferenças individuais de comportamento do avaliado no trabalho.

Para BERGAMINI (1983) "É normal e natural que, ao avaliar outra pessoa, uma série de variáveis possam aí interferir, distorcendo o retrato fiel da realidade que se pretende fazer” (p.147).

Dessa forma, sendo a avaliação um processo complexo é necessário compreender as dinâmicas de relacionamento das pessoas, verificando como elas atuam quando precisam emitir um parecer sobre as outras ou julgar seus desempenhos.

As distorções de julgamento, que afetam toda avaliação, decorrem de percepções incorretas que muitas vezes o avaliador tem do avaliado ou da situação de avaliar.

No desenvolvimento da avaliação, desvios podem acontecer durante sua dinâmica, como por exemplo, o avaliador:

1. Atribui ao avaliado suas próprias qualidades e defeitos, oferecendo um caráter muito subjetivo ao processo;

2. Considera apenas os aspectos que ele (avaliador) julga fundamentais para o avaliado;

3. Tem receio de prejudicar o avaliado que é fraco e de atribuir muitas responsabilidades àquele que é excelente, existindo uma tendência de considerar todos normalmente bons;

4. Leva em consideração apenas os últimos acontecimentos, esquecendo de fatos relevantes que possam ter acontecido no período ao qual se refere à avaliação; 
5. Supervaloriza o processo de avaliação, acreditando que sua aplicação irá corrigir o desempenho inadequado das pessoas. Por outro lado, pode desvalorizar o processo, concebendo a idéia de que a avaliação é uma prática sem valor e sem resultado para o avaliado e para a organização;

6. Não conhece as características da avaliação, emitindo julgamentos por meio do bom senso;

7. Não tem habilidade em apontar as melhorias do desempenho do avaliado quer profissionalmente quer com relação à equipe.

Muitas vezes, a existência de boatos sobre a avaliação ocasiona distorções em sua aplicação e, conseqüentemente, em seus resultados.

Dessa forma, na organização, todos os equívocos referentes ao processo de avaliação necessitam serem neutralizados por meio de controle rigoroso em sua aplicação, envolvendo a comunicação objetiva e transparente do processo, a sensibilização e preparo sistemático dos avaliadores, a construção do instrumento e o tratamento quantitativo e qualitativo das informações.

O líder precisa ter sempre em mente de que faz parte integrante de sua atuação avaliar as diferenças individuais dos funcionários que compõem sua equipe, ou seja, conseguir detectar aspectos que devam ser melhorados e recomendar medidas para o desenvolvimento e aperfeiçoamento das pessoas.

Na última avaliação de desempenho aplicada nesse hospital, o grupo de líderes salientou que, a partir de um instrumento que continha as competências gerais, havia colunas para o preenchimento da auto-avaliação, avaliação da chefia e o consenso, este obtido por meio do diálogo entre avaliador e avaliado.

Durante a discussão, detectou-se a necessidade de ter políticas específicas de recursos humanos para sustentar o processo de avaliação e gerar resultados positivos voltados à motivação da força de trabalho. 
Sem políticas claras e transparentes o processo de avaliação torna-se frágil, sendo caracterizado como uma tarefa, um dever a ser cumprido pelas partes. Nesse sentido, pode ser direcionado para aspectos pessoais e não profissionais que é a essência dessa ferramenta de gestão.

O consenso é o momento que desencadeia um diálogo entre o líder e o liderado. Para o grupo, esse contato depende dos seguintes aspectos:

- Do estilo de liderança (centralizador ou descentralizador);

- Da maturidade de ambas as partes na verbalização dos aspectos positivos e principalmente dos negativos;

- Do clima criado durante o diálogo, gerando diversos sentimentos que podem afetar a avaliação.

Dessa forma, o consenso passa a ser o momento crítico e imprescindível no processo.

É importante mencionar que a avaliação não está isolada dentro da organização. Ela não é uma simples tarefa. Faz parte de um sistema integrado de gestão de pessoas. Políticas de agregar, desenvolver e manter a força de trabalho precisam estar coerentes e transparentes a todos.

O peso que a organização atribui ao processo de avaliação é refletido na realização dos trabalhos. A maneira como a liderança conduz a avaliação, fará o colaborador dar importância ou não. Deve-se ressaltar o comprometimento de todos para que os resultados institucionais e profissionais sejam alcançados.

Além disso, deve-se verificar qual é o cenário atual do hospital e como está o clima no ambiente de trabalho, pois a existência de métodos administrativos que promovem o achatamento da estrutura organizacional e a diminuição do 
quadro funcional, por exemplo, trariam resultados da avaliação não fidedignos e insegurança a todos.

Toda avaliação caracteriza-se como uma ferramenta de gestão, cuja aplicabilidade requer atenção e cuidados por parte dos líderes.

Para esclarecer, mais objetivamente, os sentimentos dos líderes frente à avaliação, foi importante verificar o que gostaram e não gostaram no processo de avaliação ao qual foram submetidos (Quadro 6). Ficou evidenciado que a maioria não gostou, pois muitos manifestaram a não continuidade do processo, a ausência de um plano que norteasse o desenvolvimento profissional, a falta de feedback e de perspectivas futuras para o avaliado e o despreparo dos avaliadores.

Por outro lado, o processo de avaliação teve, também, boa receptividade. Desencadeou mudanças objetivas na faixa salarial, desenvolvimento de uma maturidade sobre a atividade de avaliar, principalmente, na etapa de autoavaliação, transmissão de informações sobre o desempenho profissional e a tomada de consciência do funcionário da visão do líder sobre a realização do seu trabalho. A seriedade e o clima amistoso desencadeados foram considerados, também, positivos.

A sistemática de avaliação, como instrumento complementar à administração salarial, representa a forma de apreciar o desempenho da pessoa no cargo, a fim de posicioná-la na estrutura de salários. Sendo um processo desafiador, deve ser elaborado de uma forma objetiva e clara contendo fatores de avaliação direcionados à eficiência funcional, reforçando seu caráter construtivo e contínuo. 
Quadro 6 - Fatores que agradaram e desagradaram os líderes no processo de avaliação (sentimentos).

\begin{tabular}{|c|c|c|}
\hline \multicolumn{3}{|c|}{ DO QUE VOCÊS GOSTARAM E NÃO GOSTARAM QUANDO FORAM AVALIADOS? } \\
\hline $\begin{array}{l}\text { Sujeitos } \\
\text { da } \\
\text { pesquisa } \\
\text { (SP) }\end{array}$ & Manifestações & Idéias principais \\
\hline SP3 & $\begin{array}{l}\text {... Gostei porque me fez pensar em mim mesma, sobre } \\
\text { minha atuação como profissional diante daquelas } \\
\text { questões e fui muito honesta ... }\end{array}$ & \multirow{17}{*}{$\begin{array}{l}\text { Fatores do processo } \\
\text { de avaliação que } \\
\text { agradaram os } \\
\text { líderes: } \\
\text { - Auto-avaliação como } \\
\text { ferramenta para o } \\
\text { autoconhecimento; } \\
\text { melhora da auto-estima. } \\
\text { - Conhecimento da } \\
\text { opinião da chefia sobre } \\
\text { o trabalho desenvolvido. } \\
\text { - Processo realizado } \\
\text { com seriedade. } \\
\text { - Resultou na promoção } \\
\text { profissional e melhora } \\
\text { salarial } \\
\text { - Resultou no } \\
\text { acompanhamento } \\
\text { profissional e feedback } \\
\text { - Gerou clima receptivo } \\
\text { e amistoso. }\end{array}$} \\
\hline SP5 & $\begin{array}{l}\text { O importante é ter uma idéia do que o chefe pensa de } \\
\text { você. }\end{array}$ & \\
\hline SP6 & $\begin{array}{l}\text { Saber o que a chefia pensa sobre seu trabalho ..., } \\
\text { melhorar os pontos negativos. }\end{array}$ & \\
\hline SP7 & $\begin{array}{l}\text { Gostei. Lembro de tudo, desde a minha primeira } \\
\text { avaliação, acho que tudo foi fruto profissional anos } \\
\text { depois. Avaliação mexe com a emoção das pessoas } \\
\text { avaliadas. ... Foi importante do ponto de vista da } \\
\text { leitura que se faz de si mesmo ... minha tendência } \\
\text { como auto-avaliação, sou modesta e nunca sou } \\
\text { suficiente. }\end{array}$ & \\
\hline SP8 & $\begin{array}{l}\text { Seriedade. Ouvi coisas negativas, mas bom para } \\
\text { serem corrigidas. Melhora a auto-estima. }\end{array}$ & \\
\hline SP9 & $\begin{array}{l}\text { Mudou minha faixa salarial. É um incentivo para } \\
\text { você estar melhorando, ... }\end{array}$ & \\
\hline SP11 & Pude acompanhar o meu trabalho. & \\
\hline SP13 & Mudou minha faixa salarial. & \\
\hline SP14 & Que bom avaliar as nossas competências. & \\
\hline SP17 & Gostei do retorno. & \\
\hline SP18 & $\begin{array}{l}\text { Caráter amistoso que ele dava ao falar. Deixou-me à } \\
\text { vontade. }\end{array}$ & \\
\hline SP20 & $\begin{array}{l}\text { Avaliação que recebi não estava na minha } \\
\text { expectativa. }\end{array}$ & \\
\hline SP21 & ... quando fiz minha auto-avaliação. & \\
\hline SP23 & Interação chefia-subordinado. Diálogo. & \\
\hline SP24 & Gostei...quando fui fazer minha auto-avaliação. & \\
\hline SP25 & ... foi justa e tive um aumento salarial. & \\
\hline SP26 & $\begin{array}{l}\text {... para mim a avaliação foi boa, ... estava dizendo se } \\
\text { eu iria ficar ou não ... }\end{array}$ & \\
\hline
\end{tabular}


DO QUE VOCÊS GOSTARAM E NÃO GOSTARAM QUANDO FORAM AVALIADOS?

(Continuação)

\begin{tabular}{|c|c|c|}
\hline $\begin{array}{c}\text { Sujeitos } \\
\text { da } \\
\text { pesquisa } \\
\text { (SP) }\end{array}$ & Manifestações & Idéias principais \\
\hline SP2 & ... não houve retorno, não é financeiro. & \multirow{15}{*}{$\begin{array}{l}\text { Fatores que } \\
\text { desagradaram os } \\
\text { líderes no processo } \\
\text { de avaliação: } \\
\text { - Não houve retorno, } \\
\text { feedback. } \\
\text { - Não houve perspectiva } \\
\text { de futuro e nem plano } \\
\text { de desenvolvimento } \\
\text { específico. } \\
\text { - Aspecto desagradável } \\
\text { da avaliação é a situação } \\
\text { do desconhecido. } \\
\text { - Forma de avaliação } \\
\text { imposta. } \\
\text { - Avaliador não treinado } \\
\text { apresentando dificulda- } \\
\text { des para expressar os } \\
\text { aspectos de melhoria ao } \\
\text { avaliado. }\end{array}$} \\
\hline SP3 & $\begin{array}{l}\text { Eu não gostei, porque não vi nenhuma perspectiva de } \\
\text { futuro, não vi retorno, não vi um plano, não vi a } \\
\text { utilização daquelas informações nem para o bem nem } \\
\text { para o mal. }\end{array}$ & \\
\hline SP8 & ... indiferença, estagnação. & \\
\hline SP10 & Eu não gostei porque não teve retorno ... & \\
\hline SP11 & Foi uma avaliação pontual, geral. & \\
\hline SP12 & $\begin{array}{l}\text { Não gostei. Não teve um seguimento, ... não teve um } \\
\text { plano de desenvolvimento. }\end{array}$ & \\
\hline SP14 & Avaliou, avaliou, só. Ficou por isso mesmo. & \\
\hline SP15 & Fiquei totalmente insatisfeito... & \\
\hline SP18 & ... situação do desconhecido. & \\
\hline SP19 & Não gostei de nada. & \\
\hline SP20 & ... Forma de avaliação que foi “ imposta”. & \\
\hline SP21 & $\begin{array}{l}\text { Meu avaliador não concordou com nenhum item, mas } \\
\text { também não explicou o porquê não concordava. } \\
\text { Demorei um ano para saber onde eu estava errando. }\end{array}$ & \\
\hline SP22 & $\begin{array}{l}\text {... não mudou em nada. Como se não tivesse } \\
\text { acontecido nada. } \\
\text { A falta de não se ter um resultado final cai no } \\
\text { descaso. }\end{array}$ & \\
\hline SP23 & ... o avaliador deve ser treinado para saber avaliar. & \\
\hline SP24 & Não tive retorno. & \\
\hline
\end{tabular}


Falta comentar que nas atividades dos grupos focais foram observadas diversas posturas e emoções dos líderes, que manifestavam opiniões próprias, sobre o assunto em questão, de forma objetiva e transparente.

No início das atividades, ansiedade e reflexão estavam mais presentes entre os participantes gerando informações individuais. Pouco a pouco, na medida em que outros relatos eram manifestados, as pessoas passaram a concordar, discordar ou complementar. Mesmo o grupo estando coeso, alguns líderes, por timidez, apenas respondiam quando a pesquisadora lhes dirigia a palavra adquirindo mais uma postura de observação.

Por outro lado, a maioria dos participantes evidenciou postura de empatia, seriedade, segurança, atenção e tranqüilidade ao comentarem sobre avaliação de desempenho. Com tom de voz firme e gestos coerentes demonstraram sinceridade, honestidade, equilíbrio e firmeza nas respostas. Propuseram idéias a partir das experiências vividas, opiniões coerentes sobre promoção e competências e manifestaram a relevância do trabalho em equipe, gerando aprendizagens.

O nervosismo, a angustia, o constrangimento ao falar de avaliação já recebida e da falta do feedback foram constatados, permeando os desabafos dos líderes, sendo relatados exemplos de avaliações frustrantes sem resultados satisfatórios cujas marcas persistem até hoje. 


\section{Atributos (competências) da força de trabalho e dos líderes}

\subsection{Atributos (competências) da força de trabalho}

Para a maioria dos líderes dos grupos focais, a competência profissional mais importante a ser avaliada é a competência técnica seguida de:

- Relacionamento interpessoal;

- Responsabilidade;

- Comprometimento com a instituição e com o trabalho;

- Interesse e integração com a equipe.

Além desses atributos, os grupos também destacaram as seguintes competências:

- Conhecimento científico;

- Pontualidade, assiduidade e postura;

- Comunicação;

- Capacidade de lidar com situações de conflito, inteligência emocional;

- Foco no cliente (receptividade e empatia);

- Ética profissional e alinhamento com as diretrizes institucionais;

- Perspectiva de futuro;

- Vontade de aprender;

- Inovação, criatividade;

- Iniciativa.

Esses atributos (competências) estão evidenciados no Quadro 7. 
Quadro 7 - Principais atributos (competências) da força de trabalho a serem avaliados

\begin{tabular}{|c|c|c|}
\hline $\begin{array}{l}\text { Sujeitos } \\
\text { da } \\
\text { Pesquisa } \\
\text { (SP) }\end{array}$ & Manifestações & Idéias Principais \\
\hline SP1 & 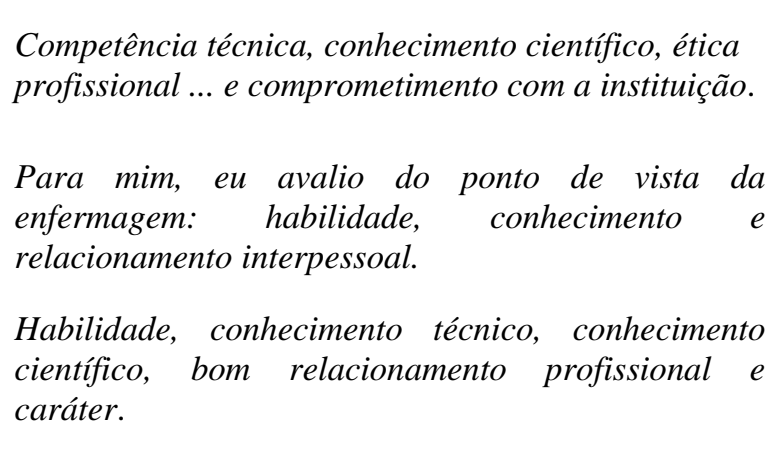 & $\begin{array}{l}\text { As seis competên- } \\
\text { cias fundamentais } \\
\text { para serem avalia- } \\
\text { das, segundo os } \\
\text { líderes: } \\
1^{\text {o }} \text { - Competência } \\
\text { técnica. }\end{array}$ \\
\hline SP2 & ... comprometimento e competência técnica. & $3^{\text {o }}$ - Responsabilidade. \\
\hline SP3 & $\begin{array}{l}\text {... se existe perspectiva de futuro ...., inteligência } \\
\text { emocional e ... a vontade de aprender, vontade de ser } \\
\text { pertencente a instituição independente do salário, ... }\end{array}$ & $\begin{array}{l}4^{\circ} \text { - Comprometimento } \\
\text { com a instituição e } \\
\text { com o trabalho. }\end{array}$ \\
\hline SP4 & $\begin{array}{l}\text { Basicamente o conhecimento científico, habilidade } \\
\text { técnica e relacionamento interpessoal. É muito } \\
\text { importante que ele seja bom ... porque se não for é } \\
\text { um risco que se coloca para o doente. }\end{array}$ & $\begin{array}{l}5^{\circ} \text { - Interesse. } \\
6^{\circ} \text { - Integração com a } \\
\text { equipe. }\end{array}$ \\
\hline SP5 & $\begin{array}{l}\text { Comunicação, capacidade para lidar com situações } \\
\text { de conflito, ... e a busca por coisas novas. }\end{array}$ & \\
\hline SP6 & $\begin{array}{l}\text {... busca por coisas novas, novos conhecimentos } e \\
\text { comunicação ... }\end{array}$ & \\
\hline SP7 & Interesse e vestir a camisa da instituição. & \\
\hline SP8 & $\begin{array}{l}\text {... conhecimento técnico, interesse,responsabilidade, } \\
\text { trabalho em equipe, ... relacionamento ... } \\
\text {... responsabilidade e disponibilidade ou seja poder } \\
\text { contar com aquela pessoa... }\end{array}$ & \\
\hline
\end{tabular}




\begin{tabular}{|c|c|c|}
\hline O QUE & CÊS ACHAM MAIS IMPORTANTE AVALIAR EM SEU & $\begin{array}{l}\text { OLABORADORES? } \\
\text { (Continuação) }\end{array}$ \\
\hline SP & Manifestações & Idéias Principais \\
\hline SP9 & $\begin{array}{l}\text { Conhecimento técnico, responsabilidade e o } \\
\text { relacionamento. }\end{array}$ & \\
\hline SP10 & $\begin{array}{l}\text { Conhecimento técnico do trabalho, competência, } \\
\text { atitude se o funcionário está alinhado com as } \\
\text { diretrizes da instituição ... } \\
\begin{array}{l}\text { Entrosamento, relacionamento, interesse, foco no } \\
\text { cliente, responsabilidade. }\end{array}\end{array}$ & \\
\hline SP11 & $\begin{array}{l}\text { Conhecimento técnico, responsabilidade, } \\
\text { capacidade de lidar com situações de conflito. E } \\
\text { mais, a pontualidade e assiduidade. }\end{array}$ & \\
\hline SP12 & $\begin{array}{l}\text { Postura, conhecimento, ter agilidade para falar com } \\
\text { um cliente, ser cortês. Eu acho fundamental: a } \\
\text { receptividade e a integração em equipe. } \\
\text {... ser criativo ... , ter iniciativa ... }\end{array}$ & \\
\hline SP14 & $\begin{array}{l}\text { O grande diferencial hoje no mercado é conseguir } \\
\text { trabalhar em equipe ... }\end{array}$ & \\
\hline SP15 & $\begin{array}{l}\text {...a parte técnica tem que estar no nível das } \\
\text { exigências, } \ldots \text { inteligência emocional, } \\
\text { relacionamento interpessoal, ... }\end{array}$ & \\
\hline SP17 & $\begin{array}{l}\text {... tem que ser tecnicamente bom, ... comunicação, ... } \\
\text { relacionamento, ... colocar-se no lugar do outro ... }\end{array}$ & \\
\hline SP18 & Qualidade e eficiência ... & \\
\hline SP20 & $\begin{array}{l}\text { Eu acho que a palavra chave é eficiência ... A } \\
\text { pessoa eficiente praticamente engloba o resto que é } \\
\text { a criatividade, a pontualidade. Tecnicamente ser } \\
\text { muito bom. }\end{array}$ & \\
\hline SP22 & $\begin{array}{l}\text { Responsabilidade, interesse e competência técnica. } \\
\text { Pontualidade e assiduidade, também, estão aí } \\
\text { incluídos. }\end{array}$ & \\
\hline SP23 & $\begin{array}{l}\text { Conhecimento técnico e científico; trabalho em } \\
\text { equipe. }\end{array}$ & \\
\hline SP24 & $\begin{array}{l}\text {... ter interesse, comprometimento com aquilo que } \\
\text { faz. }\end{array}$ & \\
\hline
\end{tabular}


Esses atributos da força de trabalho são essenciais na composição do processo de avaliação, pois todos devem desempenhar sua função corretamente, monitorando e empreendendo ações corretivas, refinando o trabalho prestado, obtendo resultado com qualidade que não ponha em risco o tratamento, os cuidados e a vida do paciente.

\subsection{Atributos (competências) dos líderes}

Por outro lado, toda liderança possui atributos importantes e necessários para a condução da sua equipe, visando a eficiência e a eficácia dos processos de trabalho. A competência técnica (ter conhecimentos específicos sobre o trabalho, saber fazer e querer fazer) constitui o elemento condutor das ações de um líder.

Durante as reuniões com os grupos, procurou-se compreender, mais objetivamente, quais são os principais atributos de uma liderança que devem ser avaliados. Conforme apresentados no Quadro 8, além da competência técnica, os líderes mencionaram:

- Saber lidar com os conflitos;

- Ter visão estratégica;

- Ter foco nas necessidades e expectativas do cliente;

- Ter habilidade em manter diálogo com as pessoas, respeitando a liberdade das mesmas;

- Ter capacidade de observar detalhes;

- Ter bom senso e ter confiança na equipe;

- Manter a união da equipe e ser modelo para a equipe;

- Ter o domínio da situação, conhecer, individualmente, cada membro da equipe;

- Ser camarada, manter clima de harmonia;

- Ter flexibilidade e tolerância, ser emocionalmente estável;

- Ter autoridade, ter jogo de cintura e ter iniciativa. 
Quadro 8 - Atributos (competências) importantes de um líder a serem
avaliados QUAIS SÃO OS ATRIBUTOS MAIS SIGNIFICATIVOS A SEREM AVALIADOS
EM UM LÍDER?

\begin{tabular}{|c|c|c|}
\hline $\begin{array}{l}\text { Sujeitos } \\
\text { da } \\
\text { pesquisa } \\
\text { (SP) }\end{array}$ & Manifestações & \multirow{7}{*}{$\begin{array}{l}\text { Atributos importantes } \\
\text { em um líder: } \\
\text {-Ter competência técnica. } \\
\text {-Saber lidar com os conflitos. } \\
\text {-Ter visão estratégica. } \\
\text {-Ter conhecimento dos objeti- } \\
\text { vos e metas a serem alcançados. } \\
\text {-Alinhar os trabalhos às } \\
\text { diretrizes da Instituição. } \\
\text {-Ter foco nas necessidades e } \\
\text { expectativas do cliente. } \\
\text {-Ter habilidade em manter diá- } \\
\text { logo com as pessoas, respeitan- } \\
\text { do a liberdade das mesmas. } \\
\text {-Ter capacidade de observar } \\
\text { detalhes }\end{array}$} \\
\hline SP5 & $\begin{array}{l}\text { O líder deve ser capaz de manter a equipe } \\
\text { unida, manter o grupo trabalhando através } \\
\text { das próprias atitudes. }\end{array}$ & \\
\hline SP8 & $\begin{array}{l}\text {... ter conhecimento pessoal de cada um, as } \\
\text { expectativas e as dúvidas dos funcionários. }\end{array}$ & \\
\hline SP9 & $\begin{array}{l}\text {... ter confiança do grupo e domínio da } \\
\text { situação. }\end{array}$ & \\
\hline SP10 & $\begin{array}{l}\text { Ter o conhecimento do pessoal, dar } \\
\text { liberdade ao funcionário chegar ao líder e } \\
\text { conversar, saber trabalhar em equipe. }\end{array}$ & \\
\hline SP11 & $\begin{array}{l}\text {... conhecer a equipe, o objetivo e a meta a } \\
\text { serem alcançados, saber lidar com os } \\
\text { conflitos e manter clima de harmonia. }\end{array}$ & \\
\hline SP12 & $\begin{array}{l}\text {... ter a capacidade para aglutinar todos os } \\
\text { funcionários ao seu redor. }\end{array}$ & \\
\hline SP13 & $\begin{array}{l}\text { Ter visão estratégica, saber alinhar os } \\
\text { trabalhos às diretrizes da instituição, ter } \\
\text { foco no cliente e comunicação interpessoal. }\end{array}$ & $\begin{array}{l}\text {-Ter bom senso. } \\
\text {-Manter a união da equipe. }\end{array}$ \\
\hline SP14 & $\begin{array}{l}\text { Ser estável emocionalmente, gostar de } \\
\text { gente, ser centrado, enxergar as coisas. }\end{array}$ & -Ser modelo para a equipe. \\
\hline SP18 & Ter autoridade, saber mediar conflitos. & \\
\hline SP20 & $\begin{array}{l}\text {... ser camarada, ter jogo de cintura, ser } \\
\text { tolerante, conhecer muito aquilo que faz, ter } \\
\text { iniciativa e um pouco de psicologia. }\end{array}$ & $\begin{array}{l}\text {-Conhecer, individualmente, } \\
\text { cada membro da equipe; ser } \\
\text { camarada. }\end{array}$ \\
\hline SP21 & $\begin{array}{l}\text { Ter flexibilidade, } \\
\text { racionalidade, conhecimento, } \\
\text { conflitos. }\end{array}$ & $\begin{array}{l}\text {-Manter clima de harmonia. } \\
\text {-Ter flexibilidade e tolerância. }\end{array}$ \\
\hline SP22 & Capacidade de observar os detalhes. & $\begin{array}{l}\text { - Ter autoridade. } \\
\text {-Ser emocionalmente estável. }\end{array}$ \\
\hline SP23 & ... ter bom senso. & $\begin{array}{l}\text {-Ter jogo de cintura. } \\
\text {-Ter iniciativa. }\end{array}$ \\
\hline
\end{tabular}




\section{Atitudes dos líderes evidenciadas}

Quanto à maneira de realizar a avaliação (Quadro 9), os líderes mencionaram que a avaliação no dia-a-dia necessita de sensibilidade do avaliador para, além de fornecer feedback à pessoa, dar um caráter de aprendizado.

Criar um ambiente favorável que permita a existência de um diálogo, por meio do qual o funcionário compreenda o que é certo e o que deverá melhorar, constitui, para os líderes dos grupos focais, mecanismo que gera mais resultados.

Esse feedback imediato, que é realizado de forma assistemática, passa a ser uma importante ferramenta para corrigir passo-a-passo o desempenho do funcionário durante o processo de trabalho, obtendo a qualidade do serviço prestado.

O feedback precisa ser sempre moldado para a pessoa a que é dirigido. Nesse contexto, é um instrumento muito útil para o gestor que necessita ter habilidade para aplicá-lo, obrigando-o a compreender e conhecer melhor cada membro da equipe.

A avaliação de desempenho, de caráter formal e sistemático, feita uma vez por ano com a utilização de uma entrevista, gerando comunicação e discussão dos itens avaliados, procura diminuir as dificuldades de interação entre superior hierárquico e subordinado. Esse processo, para os líderes dos grupos focais, torna-se pouco prático, pois não gera resultado a médio prazo e nem a longo prazo, ficando no cumprimento de uma tarefa para ambas as partes.

Apesar disso, os líderes mencionam os cuidados que tomam durante o exercício de avaliação, procurando propiciar um momento de troca e de aprendizado com o funcionário. Esses cuidados são referentes: ao local adequado, confortável e previamente reservado; ao envolvimento de outras chefias, para ser obtida uma visão sistêmica do desempenho da pessoa, além 
de propiciar participação de toda a equipe no processo de avaliação; ao instrumento de avaliação e às informações do avaliado que precisam estar corretas; às etapas do processo, iniciando com a auto-avaliação seguida da avaliação da chefia e finalizando com o consenso; à sinceridade e ao caráter dos avaliadores.

Para alguns líderes, o motivo da avaliação (Quadro 9) é a busca constante da melhoria dos processos de trabalho, do alinhamento entre os objetivos da área e a participação das pessoas para alcançá-los e do crescimento da pessoa na organização. Para a maioria dos líderes, o motivo constitui simplesmente o fato da obrigatoriedade em cumprir uma tarefa institucional.

\section{Quadro 9 - Como avaliar e o motivo da avaliação (atitudes)}

QUANDO VOCÊS PRECISAM AVALIAR ALGUÉM, COMO VOCÊS FAZEM? O QUE MOTIVA VOCÊS A AVALIAREM ALGUÉM?

\begin{tabular}{|c|c|c|}
\hline $\begin{array}{l}\text { Sujeitos } \\
\text { da } \\
\text { pesquisa } \\
\text { (SP) }\end{array}$ & Manifestações & Idéias importantes \\
\hline SP1 & $\begin{array}{l}\text {... ir anotando não dá certo. Por que comentar } \\
\text { coisas passadas? Acho que para o meu } \\
\text { temperamento você tem que ir corrigindo dia-a- } \\
\text { dia,... }\end{array}$ & $\begin{array}{l}\text { COMO avaliar: } \\
\text { - Corrigir o desempenho diaria- } \\
\text { mente, no local de trabalho, é o } \\
\text { mais usual, considerando o perfil } \\
\text { do funcionário. }\end{array}$ \\
\hline SP3 & $\begin{array}{l}\text { Existem momentos que a avaliação é mais } \\
\text { formal, mas as avaliações do dia-a-dia } \\
\text { constroem a sua área, o seu trabalho, o seu } \\
\text { relacionamento com o funcionário,... } \\
\text {...tem aquele funcionário que você precisa dar o } \\
\text { feedback o tempo inteiro ... e existe aquele que } \\
\text { exige: “por favor não me toque que eu vou } \\
\text { sozinho". } \\
\text { Então, você tem que perceber o perfil do seu } \\
\text { avaliado e ter um jogo de cintura para tirar dele } \\
\text { o que você precisa. }\end{array}$ & $\begin{array}{l}\text { - Avaliar os pontos fracos, fortes, } \\
\text { pontualidade, assiduidade e } \\
\text { valorizar os acertos. } \\
\text { - Fornecer orientações sobre os } \\
\text { procedimentos e questões críticas } \\
\text { em uma sala privativa; não expor } \\
\text { o funcionário. } \\
\text { - Fornecer orientações a todos os } \\
\text { funcionários na passagem de } \\
\text { plantão. }\end{array}$ \\
\hline
\end{tabular}




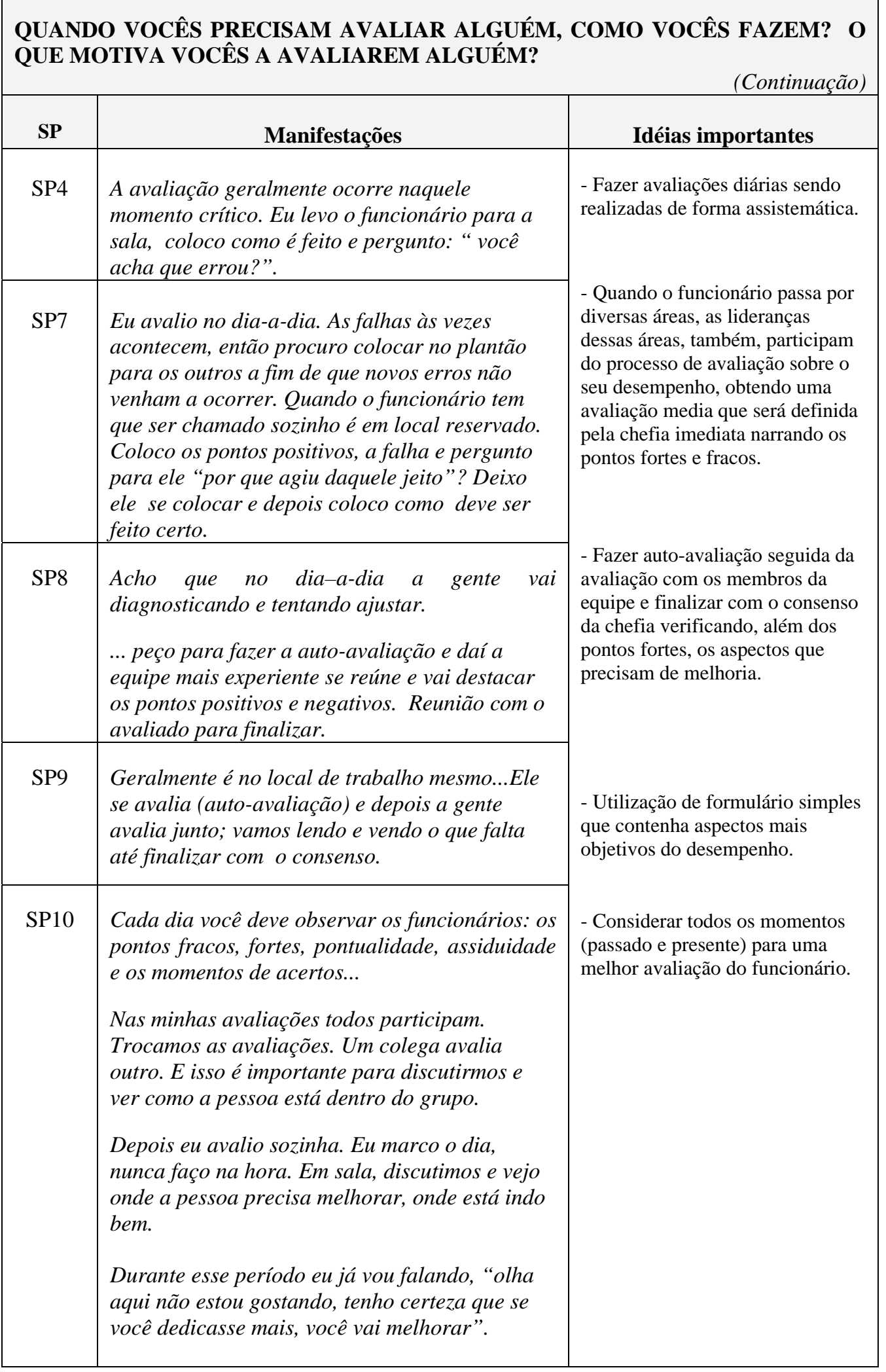


QUANDO VOCÊS PRECISAM AVALIAR ALGUÉM, COMO VOCÊS FAZEM? O QUE MOTIVA VOCÊS A AVALIAREM ALGUÉM?

(Continuação)

\begin{tabular}{|c|c|c|}
\hline SP & Manifestações & Idéias importantes \\
\hline SP11 & $\begin{array}{l}\text { Eu faço a pré-avaliação antes de finalizar a } \\
\text { própria avaliação do funcionário. Ele passa por } \\
\text { todas as nossas áreas para ter uma pontuação em } \\
\text { cada área. Ele passa por pré-avaliações dos } \\
\text { responsáveis pelos setores, funcionários e } \\
\text { colaboradores dele. Isso é importante para } \\
\text { ponderar a avaliação média desse funcionário. } \\
\text { Finalizar a avaliação, conversando e indicando os } \\
\text { pontos a serem melhorados. }\end{array}$ & \\
\hline SP13 & $\begin{array}{l}\text { Peço para a pessoa fazer a auto-avaliação. Depois } \\
\text { avaliação conjunta. Discuto para chegar a um } \\
\text { consenso. }\end{array}$ & \\
\hline SP14 & $\begin{array}{l}\text {...fazemos a avaliação a todo momento, de } \\
\text { maneira assistemática. Se for mais uma coisa } \\
\text { técnica normalmente eu chamo o funcionário e } \\
\text { explico o que está acontecendo, o que não está } \\
\text { funcionando bem. Mas é assistemático. }\end{array}$ & \\
\hline SP15 & $\begin{array}{l}\text { A avaliação é diária. Todo o contato que você vai } \\
\text { tendo com o funcionário dá para sentir como ele } \\
\text { se comporta no trabalho, como ele se comporta ou } \\
\text { se comportou diante de um fato. É uma atividade } \\
\text { diária das chefias. }\end{array}$ & \\
\hline SP19 & $\begin{array}{l}\text { Recebo a avaliação e entrego para os funcionários } \\
\text { que fazem a auto-avaliação. Converso } \\
\text { individualmente. Cria uma expectativa muito } \\
\text { grande. Tento amenizar a situação. Tento evitar o } \\
\text { estresse. Discuto pontos divergentes. }\end{array}$ & \\
\hline SP20 & $\begin{array}{l}\text {...A forma que tenho é simples. O formulário tem } \\
\text { quatro questões em cada item. Você opta por uma } \\
\text { dessas questões. Você analisa o funcionário e a } \\
\text { única coisa que você tem que fazer é colocar um X. } \\
\text { Você tem que ser sincero e ser calculista para não } \\
\text { cometer nenhum erro. Se for uma avaliação de } \\
\text { aspectos pessoais é mais difícil porque já entram } \\
\text { outras coisas que o questionário não pede. } \\
\text { Via de regra o que vale no hospital é o formulário. }\end{array}$ & \\
\hline
\end{tabular}



QUANDO VOCÊS PRECISAM AVALIAR ALGUÉM, COMO VOCÊS FAZEM? O
QUE MOTIVA VOCÊS A AVALIAREM ALGUÉM?

(Continuação)

\begin{tabular}{|c|c|c|}
\hline SP & Manifestações & Idéias importantes \\
\hline SP21 & $\begin{array}{l}\text { À medida que os problemas vão surgindo } \\
\text { vamos avaliando, vai questionando e } \\
\text { corrigindo porque aconteceu aquilo, o que } \\
\text { levou a errar ou não. Então é no dia-a-dia } \\
\text { mesmo. }\end{array}$ & \\
\hline SP22 & $\begin{array}{l}\text { Para avaliar, pensar no que aconteceu no ano } \\
\text { passado, não apenas no momento presente. } \\
\text { Não pensar só nos momentos ruins. Mas sim } \\
\text { uma somatória de todos os momentos. }\end{array}$ & \\
\hline SP23 & $\begin{array}{l}\text { Converso individualmente. O funcionário tem } \\
\text { plena liberdade de falar o que ele acha. Avalio } \\
\text { a aparência pessoal também. Eu quero ter } \\
\text { confiança dos funcionários. Gosto de avaliar o } \\
\text { funcionário como parte de um grupo. }\end{array}$ & \\
\hline SP24 & $\begin{array}{l}\text {... foco diariamente. Vou corrigindo } \\
\text { pontualmente, é uma forma do grupo crescer. } \\
\text { O erro ajuda no crescimento. E o erro mais } \\
\text { grave eu pontuo individualmente, } \\
\text { conversando. } \\
\text { Processo de avaliação do funcionário, } \\
\text { geralmente vem da diretoria com solicitação } \\
\text { formal de avaliação. Aí tem sempre uma regra } \\
\text { para ser seguida... é formal e individual. } \\
\text { Muitas vezes solicito sugestões. Acho que é } \\
\text { importante a pessoa que estiver sendo } \\
\text { avaliada também sugerir. Não é só eu como } \\
\text { chefe a sugerir e avaliar..."e se nós fizéssemos } \\
\text { dessa forma será, que vamos melhorar?” }\end{array}$ & \\
\hline SP26 & $\begin{array}{l}\text { Eu vou anotando tudo o que aconteceu, depois } \\
\text { a gente conversa, senta, faz uma reunião } \\
\text { informal para discutir. }\end{array}$ & \\
\hline
\end{tabular}




\begin{tabular}{|c|c|c|}
\hline \multicolumn{3}{|c|}{$\begin{array}{l}\text { QUANDO VOCÊS PRECISAM AVALIAR ALGUÉM, COMO VOCÊS FAZEM? O } \\
\text { QUE MOTIVA VOCÊS A AVALIAREM ALGUÉM? } \\
\text { (Continuação) }\end{array}$} \\
\hline SP & Manifestações & Idéias importantes \\
\hline SP3 & $\begin{array}{l}\text { Se eu estou avaliando é em cima de valores. } \\
\text { Quando eu vislumbro uma oportunidade de } \\
\text { melhoria eu avalio o funcionário no dia-a-dia. }\end{array}$ & $\begin{array}{l}\text { O QUE os motiva avaliar: } \\
\text {-Busca constante da } \\
\text { melhoria dos processos de } \\
\text { trabalho. }\end{array}$ \\
\hline SP4 & $\begin{array}{l}\text { Motivação. Quando ele comete uma falha ou } \\
\text { surgem situações que o funcionário pede para ser } \\
\text { avaliado. }\end{array}$ & $\begin{array}{l}\text {-Alinhamento entre os } \\
\text { objetivos da área e a } \\
\text { participação das pessoas } \\
\text { para alcançá-los. }\end{array}$ \\
\hline SP7 & $\begin{array}{l}\text {...Se o funcionário é bom eu procuro fazer alguma } \\
\text { coisa em troca, eu procuro compensar de outra } \\
\text { forma. }\end{array}$ & $\begin{array}{l}\text {-Crescimento da pessoa na } \\
\text { organização. }\end{array}$ \\
\hline SP9 & $\begin{array}{l}\text { Hoje, o que motiva é a obrigação de você fazer a } \\
\text { avaliação ... }\end{array}$ & $\begin{array}{l}\text {-Apenas a obrigação de } \\
\text { avaliar. }\end{array}$ \\
\hline SP11 & $\begin{array}{l}\text { O que leva é a obrigação. Não há estímulo } \\
\text { nenhum. Não leva para nenhum resultado. }\end{array}$ & \\
\hline SP15 & $\begin{array}{l}\text { Perspectiva para a pessoa. Precisa ter alguma } \\
\text { coisa a retribuir para a pessoa avaliada. }\end{array}$ & \\
\hline
\end{tabular}

Cabe lembrar que nenhuma prática organizacional, como é o caso do processo de avaliação, deve ser vista como uma situação resolvida em definitivo. As críticas e as correções sistemáticas necessárias à avaliação constituem elementos essenciais para ampliarem a visão dos avaliadores para o aprimoramento do processo, tornando-o mais adaptado às transformações da organização, bem como gerarem condições para uma aprendizagem continuada. 


\section{Contribuições para a eficiência da avaliação}

Segundo os líderes do estudo, conforme evidenciado no Quadro 10, o instrumento de avaliação precisa:

- Apresentar as competências profissionais.

- Ter perguntas claras e básicas para direcionar a avaliação.

- Ter um espaço aberto para o avaliador se manifestar livremente sobre o avaliado.

- Considerar as características de cada área e não ser engessado.

- Ter uma estrutura padrão apresentando itens institucionais, além de tópicos referentes a cada área e a cada função (“estrutura customizada”).

- Diminuir a subjetividade, alinhando os resultados da avaliação aos indicadores da área.

- Separar por atividades de acordo com a estrutura funcional de recursos humanos.

- Ter a identificação do avaliado e questões sob medida das áreas, verificando os aspectos técnicos, emocionais e atitudinais.

Quadro 10 - Formulário de avaliação e forma de apresentação dos resultados (contribuições)

\begin{tabular}{|c|c|c|}
\hline \multicolumn{3}{|c|}{$\begin{array}{l}\text { SUPONHAMOS QUE NÃO HOUVESSE NENHUM FORMULÁRIO DE } \\
\text { AVALIAÇÃO E QUE VOCÊS TIVESSEM QUE CRIAR UM. QUAIS } \\
\text { INFORMAÇÕES VOCÊS COLOCARIAM? COMO SERIA A FORMA DE } \\
\text { APRESENTAR OS RESULTADOS? }\end{array}$} \\
\hline \multicolumn{3}{|c|}{\begin{tabular}{c|c|c}
$\begin{array}{c}\text { Sujeitos } \\
\text { da } \\
\text { pesquisa } \\
\text { (SP) }\end{array}$ & Manifestações & Idéias principais \\
\end{tabular}} \\
\hline \multicolumn{3}{|c|}{$\begin{array}{l}\text { Colocaria como informaçoes } \\
\text { conhecimento científico, bom } \\
\text { relacionamento profissional e em equipe, } \\
\text { relacionamento com o paciente e família, } \\
\text { postura profissional. Nesta postura } \\
\text { profissional o caráter da pessoa com } \\
\text { relação ao colega e a instituição. } \\
\text { Equilíbrio em momentos de conflito e em } \\
\text { situações críticas. }\end{array}$} \\
\hline SP5 & $\begin{array}{l}\text { Criar instrumento de avaliação adequado a } \\
\text { cada tipo de trabalho desempenhado. }\end{array}$ & \\
\hline
\end{tabular}


SUPONHAMOS QUE NÃO HOUVESSE NENHUM FORMULÁRIO DE
AVALIAÇÃO E QUE VOCÊS TIVESSEM QUE CRIAR UM. QUAIS
INFORMAÇÕES VOCÊS COLOCARIAM? COMO SERIA A FORMA DE
APRESENTAR OS RESULTADOS?

(Continuação)

\begin{tabular}{|c|c|c|}
\hline SP & Manifestações & Idéias principais \\
\hline SP6 & $\begin{array}{l}\text { Imaginar um único formulário é } \\
\text { complicado. A outra coisa é imaginar que } \\
\text { precisa ter o perfil da área, porque cada } \\
\text { uma tem a sua particularidade. Alterar de } \\
\text { tempo em tempo o perfil e a competência } \\
\text { do funcionário da área, conforme as } \\
\text { estratégias e as diretrizes da instituição. }\end{array}$ & 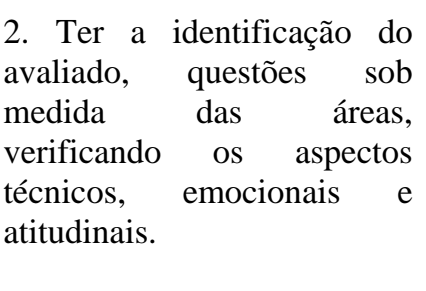 \\
\hline SP8 & $\begin{array}{l}\text { Perguntas básicas com opção para poder } \\
\text { escrever explicando melhor o que a gente } \\
\text { quer. } \\
\text { á é adequar cada formulário para cada } \\
\text { área e fixar valores. } \\
\text { Se eu tivesse que montar um formulário, eu } \\
\text { faria por tópicos: } \\
\text { 1. Identificação do funcionário; } \\
\text { 2. Grupo de questões que poderia variar de } \\
\text { serviço a serviço: } \\
\text { 2.1. módulos que tenham avaliação } \\
\text { técnica e profissional. } \\
\text { 2.2. módulo que tenha avaliação da } \\
\text { capacidade emocional-equilíbrio emocio- } \\
\text { nal. } \\
\text { 2.3. módulo da parte ética, } \\
\text { responsabilidade e caráter. }\end{array}$ & $\begin{array}{l}\text { 3. Inserir as competências } \\
\text { profissionais. } \\
\text { 4. Ter perguntas claras e } \\
\text { básicas. } \\
\text { 5. Ter um campo aberto para } \\
\text { o avaliador se manifestar } \\
\text { livremente sobre o avaliado. } \\
\text { 6. Considerar as } \\
\text { características de cada área e } \\
\text { não ser engessado. } \\
\text { 7. Diminuir a subjetividade, } \\
\text { alinhando os resultados da } \\
\text { avaliação aos indicadores da } \\
\text { área. }\end{array}$ \\
\hline SP9 & $\begin{array}{l}\text { Perguntas básicas que auxiliam a fazer } \\
\text { uma avaliação e depois colocar o que você } \\
\text { acha de cada um, a critério da chefia. }\end{array}$ & $\begin{array}{l}\text { 8. Separar por atividades de } \\
\text { acordo com a estrutura } \\
\text { funcional de recursos } \\
\text { humanos. }\end{array}$ \\
\hline SP10 & $\begin{array}{l}\text {.. ter uma parte para escrever sobre o } \\
\text { funcionário. Tenho dificuldades para } \\
\text { encaixar o funcionário num determinado } \\
\text { item. }\end{array}$ & \\
\hline SP11 & $\begin{array}{l}\text { Permitir um campo aberto para poder } \\
\text { melhor avaliar e pontuar. }\end{array}$ & \\
\hline
\end{tabular}



SUPONHAMOS QUE NÃO HOUVESSE NENHUM FORMULÁRIO DE
AVALIAÇÃO E QUE VOCÊS TIVESSEM QUE CRIAR UM. QUAIS
INFORMAÇÕES VOCÊS COLOCARIAM? COMO SERIA A FORMA DE
APRESENTAR OS RESULTADOS?

\begin{tabular}{|c|c|c|}
\hline SP & Manifestações & Idéias principais \\
\hline SP13 & $\begin{array}{l}\text { Eu acho importante num instrumento de } \\
\text { avaliação tentar diminuir a subjetividade. } \\
\text { Então se você conseguir contrapor os } \\
\text { resultados de uma avaliação com os } \\
\text { indicadores da área acho que seria } \\
\text { interessante. }\end{array}$ & \\
\hline SP19 & $\begin{array}{l}\text {... aperfeiçoaria o que já existe, separando } \\
\text { por atividades. Por exemplo: nível } \\
\text { gerencial e operacional. }\end{array}$ & \\
\hline SP22 & $\begin{array}{l}\text { Pegar os itens institucionais existentes e } \\
\text { montar um modelo padrão e acrescentar } \\
\text { mais ou menos cinco itens abertos para } \\
\text { cada tipo de área, para cada tipo de } \\
\text { função. }\end{array}$ & \\
\hline SP1 & $\begin{array}{l}\text {... acho que as fragilidades têm que ser } \\
\text { preservadas } \quad \text { e trabalhadas } \\
\text { individualmente, agora o resultado global } \\
\text { tem que ser exposto. }\end{array}$ & $\begin{array}{c}\text { Resultados } \\
\text { - Trabalhar individualmente }\end{array}$ \\
\hline SP4 & $\begin{array}{l}\text {... as informações construtivas, seriam } \\
\text { expostas, mas outras coisas seriam } \\
\text { reservadas. }\end{array}$ & $\begin{array}{l}\text { expor o funcionário. } \\
\text { - Expor os resultados globais }\end{array}$ \\
\hline SP5 & $\begin{array}{l}\text { Ter valores básicos e móveis para avaliar, } \\
\text { não engessado. }\end{array}$ & - Pontuar os itens gerais de \\
\hline SP11 & $\begin{array}{l}\text {...pontuações diferentes para cada área } \\
\text { elaborando média, uma ponderação. As } \\
\text { pontuações e as ponderações são muito } \\
\text { importantes. }\end{array}$ & $\begin{array}{l}\text { atividades do funcionário. } \\
\text { - Pontuar itens específicos, } \\
\text { por área de interesse, }\end{array}$ \\
\hline SP19 & $\begin{array}{l}\text { Além daquela pontuação natural para cada } \\
\text { item que você quantifica de acordo com a } \\
\text { atividade da pessoa, pontuar por área de } \\
\text { interesse, dando peso maior ou menor a } \\
\text { cada pergunta. }\end{array}$ & $\begin{array}{l}\text { menores. } \\
\text { - Pontuações não rígidas, } \\
\text { caracterizadas com valores } \\
\text { ponderados. }\end{array}$ \\
\hline SP23 & $\begin{array}{l}\text {... com pontuações não rígidas, talvez com } \\
\text { abertura maior. }\end{array}$ & \\
\hline
\end{tabular}


Construir um instrumento de avaliação que seja objetivo, claro e tenha sua aplicabilidade de forma contínua e eficaz, garantindo o desenvolvimento do funcionário, torna-se uma tarefa árdua e complexa. O formulário, como instrumento de avaliação, deve passar por um processo rigoroso de elaboração e controle de sua validade. Ao mesmo tempo em que se pretende que o líder faça uma avaliação coerente da pessoa, o formulário deve, também, procurar ajudálo a não ser incoerente nas informações.

Assim, a preocupação volta-se não apenas para o conteúdo do formulário, mas, também, para as orientações que serão necessárias a todos os envolvidos em cada etapa do processo de avaliar. Vale ressaltar que o formulário deve conter itens apropriados para as diferentes áreas de atuação.

De acordo com BERGAMINI (1983) as principais partes que compõem um instrumento de avaliação são:

- Identificação do avaliado;

- Instruções claras e simples, ou seja, esclarecimentos importantes a serem seguidos pelo avaliador para o preenchimento do formulário de avaliação;

- Descrição das principais atividades realizadas pelo avaliado;

- Itens a serem avaliados com seus respectivos níveis de complexidade e um espaço reservado para observações complementares pertinentes;

- Conclusões finais que têm o objetivo de validar as informações já registradas e descrever ações para o desenvolvimento do avaliado.

Para a elaboração de um instrumento de avaliação, são considerados os objetivos claros e o conteúdo, além da própria demanda a ser avaliada. Esses aspectos do formulário são importantes, pois determinam o tipo de questionamento e o método a ser utilizado.

A utilização de questões abertas propicia maior liberdade para o avaliador se expressar sobre o desempenho do avaliado, tornando complexa sua tabulação conforme manifestado por alguns líderes: Espaços abertos são importantes para o 
“feedback”, para a gente melhorar ..., não dá para avaliar (SP13); ... para 3000 funcionários faria uma coisa fechada. Se fosse menos funcionários dá para fazer uma coisa aberta (SP8).

Os métodos, tais como: dinâmicas de grupo, jogos, provas escritas e práticas foram lembrados pelos líderes no caso de avaliações específicas dependendo da demanda a ser avaliada: ... para um número restrito faria tipo uma dinâmica de grupo para as pessoas serem avaliadas em situações a serem criadas, um jogo para avaliar a capacidade de liderança e o nível emocional...(SP8); ... acho que dentro dos instrumentos seria interessante colocar alguma coisa como avaliar a habilidade técnica (prova escrita e prática)... (SP17).

O sucesso de uma avaliação vai depender dos objetivos do próprio processo de avaliação, ou seja, daquilo que se visa obter das informações levantadas que devem ser bem objetivas e explícitas para não ocorrer dupla interpretação pelos avaliadores e, enfim, do próprio instrumento de avaliação que precisa ser concebido a partir da cultura e condições da organização.

Além dos aspectos referentes ao conteúdo, os grupos discutiram formas de obter valores e apresentar os resultados. Assim, a pontuação, por meio de conceitos (muito bom, bom, regular,...), foi considerada como mecanismo válido para o processo de avaliação, apresentando como características a não rigidez e pesos diferentes para as perguntas, de acordo com as especificidades das áreas, para que possam gerar valores mais fiéis.

Quanto à apresentação dos resultados, os líderes mencionaram a importância de respeitar a individualidade dos avaliados não expondo informações que possam afetar a auto-estima.

BERGAMINI (1983) enfatiza que os pontos críticos de cada um nunca devem ser feitos coletivamente. Em um processo de avaliação, a pessoa avaliada necessita saber que a avaliação é uma dinâmica que apresenta um retrato fiel da 
realidade do trabalho e não um ajuste de contas. O avaliado deve saber que possui qualidades que precisam ser conservadas e aspectos do seu desempenho que necessitam de melhorias. O avaliado deve tomar consciência de que o instrumento de avaliação constitui um registro de seu progresso na organização e não uma ferramenta de punição.

Enfim, em todos os grupos, os líderes procuraram ser minuciosos em suas respostas, explicando com detalhes o seu ponto de vista, colocando-se ora no papel de avaliados e ora no papel de avaliadores. 


\section{CONCLUSÕES}

A partir da análise do conteúdo das manifestações das lideranças, que refletiram suas expectativas, sentimentos e atitudes para com o processo de avaliação de desempenho, pode-se concluir:

1. Todo processo de avaliação de desempenho é imprescindível nas organizações e precisa estar alinhado com as diretrizes institucionais e com ações resultantes de políticas coerentes de gestão de pessoas como, por exemplo, planos de carreira.

2. Deve existir transparência, objetividade e ética na dinâmica da avaliação para não se tornar um processo altamente subjetivo, sem critérios e sem resultados.

3. A avaliação vista como processo precisa ter continuidade, gerando plano de desenvolvimento do funcionário com foco em competências que necessitam de melhorias e não ser uma ferramenta punitiva, injusta e de descontentamento.

4. Os avaliadores devem estar capacitados, tanto do ponto de vista técnico quanto emocional, para realizarem a avaliação e propiciarem momentos receptivos de feedback e aprendizagem, respeitando a individualidade do avaliado.

5.Elaboração de um instrumento objetivo de avaliação que apresente as competências técnicas e comportamentais e que considere também as manifestações das lideranças.

6. Mudança da terminologia de avaliação de desempenho para verificação das competências, a ser aplicada nas lideranças e na força de trabalho, com foco sempre direcionado para a estruturação e acompanhamento de um plano de desenvolvimento profissional. 


\section{CONSIDERAÇÕES FINAIS}

Toda instituição hospitalar é considerada uma empresa com características peculiares porque envolve complexa associação de pessoas capacitadas e diversos equipamentos para a prestação de assistência à população. Compreender e reconhecer essa atividade hospitalar como negócio e compatibilizar esse conceito com sua função dirigida à sociedade, exigem uma gestão administrativa composta por líderes éticos, competentes e compromissados com os funcionários, os clientes e com as demais partes interessadas.

O foco em gestão de pessoas requer que as organizações com rumo à excelência, implementem ações que estejam alinhadas às suas estratégias, gerando contínua aprendizagem e comprometimento de todos. Avaliar o desempenho, com foco em competências previamente definidas nos cargos, é considerado uma dessas ações e constitui desafio para todo gestor.

Este estudo possibilitou conhecer, segundo a ótica das lideranças de uma instituição pública, o processo de avaliação de desempenho, procurando revelar os aspectos essenciais para sua eficiência. Assim, foi importante destacar e analisar as expectativas, os sentimentos, as atitudes e as contribuições dos líderes, obtidos por meio da técnica de grupo focal, onde participantes elaboravam melhor suas idéias e expunham suas opiniões e experiências aos outros com possibilidades de desenvolvimento para todos.

Com relação à avaliação, os líderes destacaram alguns aspectos que consideram importantes: a auto-avaliação, propiciando o autoconhecimento e a melhora da auto-estima; o conhecimento da opinião da chefia sobre o trabalho realizado; o acompanhamento do desempenho do profissional por meio de feedback construtivo e educativo; a seriedade de todos na condução do processo de avaliação; a promoção profissional e conseqüente melhora salarial; o clima amistoso e o diálogo entre chefe-subordinado. 
Por outro lado, o processo de avaliação de desempenho pode gerar situações negativas, ocasionando constrangimentos e frustrações decorrentes da não continuidade do processo, pela organização, ficando apenas o cumprimento de uma tarefa; da presença de subjetividade; da ausência de critérios; da falta de preparo e amadurecimento dos avaliadores para o processo de avaliação; da existência de um cenário organizacional incompatível com o momento da avaliação, causando incomodo para todos; e dos sentimentos de inutilidade e de injustiça.

A postura da liderança, frente ao exercício da avaliação, assim como seu interesse e compromisso, refletem de modo significativo na importância que os funcionários expressam a essa prática.

A maneira de como fazer uma avaliação (formal ou informal) merece atenção do líder a fim de tornar o processo uma ocasião para troca e aprendizado. O feedback imediato constitui a ferramenta mais importante para a melhoria do desempenho profissional. Esse tipo de intervenção requer certa sensibilidade e treinamento do líder que precisa estabelecer um diálogo com o funcionário e criar um clima amistoso de aprendizado. Necessita saber o momento certo de dar o feedback construtivo e educativo, como também deve aprender a recebê-lo.

Para os líderes, corrigir o desempenho do funcionário diariamente, no local de trabalho, é o mais usual, avaliando os pontos fracos e fortes, sobretudo, valorizando os acertos. É importante fornecer orientações sobre os procedimentos e as ações críticas em uma sala privativa, não expondo o funcionário e, também, utilizar a passagem de plantão para reforçar orientações à equipe.

Quanto às contribuições dos líderes para a estruturação de um instrumento de avaliação, mencionaram sua padronização que deve conter: descrição das competências profissionais; identificação completa do avaliado; perguntas ou afirmações claras e básicas de fácil entendimento, sob medida da área, dos aspectos atitudinais, emocionais e técnicos, respeitando a estrutura funcional da organização 
(nível gerencial, nível operacional, dentre outros) e espaço aberto para o avaliador se manifestar livremente sobre o avaliado. Ressaltaram, também, a presença de menor subjetividade alinhando os resultados da avaliação com os indicadores de desempenho da área.

Aquele que trabalha em uma instituição de saúde deve ser competente tecnicamente, e preocupar-se com o ser humano, saber fazer e sentir-se satisfeito com aquilo que faz. Se as pessoas não estiverem comprometidas com a vida da organização, não assumirão plena responsabilidade e nem conseguirão ser realmente eficientes. As pessoas devem interagir com as que trabalham em outras áreas, desenvolvendo ações em equipe para melhor prestar serviços à sociedade.

Isso quer dizer que a avaliação precisa estar relacionada aos aspectos comportamentais (atitude) do ser humano e às questões técnicas. A aplicação de uma ferramenta direcionada somente ao caráter técnico traz resultados insatisfatórios.

As organizações buscam formas participativas e inovadoras de avaliar o desempenho de sua força de trabalho que lhes tragam resultados imediatos e mais concretos e que tenham foco no futuro.

Enquanto que a avaliação de desempenho tradicional olha para o passado, considerando os requisitos técnicos que já ocorreram, a avaliação de desempenho com foco em competências olha para o futuro, para o desenvolvimento das pessoas onde as informações do passado servem para criar novas estratégias e pontos de melhoria.

O estudo mostrou que avaliar é um processo complexo para os líderes, os quais esperam formas mais objetivas e eficientes de avaliação, gerando resultados consistentes para o funcionário e para a organização. Em resposta a esta expectativa, a avaliação de desempenho com foco em competências pode garantir para a instituição e para os líderes um modelo de gestão de pessoas direcionado à verificação das competências, ao estabelecimento de um plano de desenvolvimento 
para as mesmas e ao acompanhamento das melhorias do desempenho. Esta avaliação deve ser estrategicamente usada para investir na equipe, visualizando os resultados a serem alcançados por meio das pessoas.

O mercado sempre nos levará para mudanças imprescindíveis à sobrevivência das organizações e, conseqüentemente, os processos de gestão de pessoas também deverão ser atualizados principalmente na direção de competências.

Por meio das informações contidas na revisão da literatura e das manifestadas pelos líderes, este estudo evidenciou que é grande o trabalho a ser realizado em transformar avaliação de desempenho em uma ferramenta de gestão voltada ao desenvolvimento e aperfeiçoamento das competências.

O importante é seguir uma linha de trabalho que seja coerente com a realidade da organização, respeitando sua cultura e diretrizes, para ser aplicada de forma rápida, eficiente e eficaz. 


\section{REFERÊNCIAS}

Almeida MIR. Manual de planejamento estratégico: desenvolvimento de um plano estratégico com a utilização de planilhas Excel. 2.ed. São Paulo: Atlas; 2003.

Alves-Mazzotti AJ. O debate contemporâneo sobre os paradigmas. In: AlvesMazzotti AJ, Gewandsznajder F. O método nas ciências naturais e sociais: pesquisa quantitativa e qualitativa. 2.ed. São Paulo: Pioneira; 1999. cap 6.

Bardin, Laurence. Análise de conteúdo. Lisboa: Edições 70; 1988.

Bergamini, Cecília Whitaker. Liderança: administração do sentido. São Paulo: Atlas; 1994.

Bergamini, Cecília Whitaker. Avaliação de desempenho humano na empresa. 3.ed. São Paulo: Atlas; 1983.

Bertelli, Sandra Benevento. Gestão de pessoas em administração hospitalar. Rio de Janeiro: Qualitymark; 2004.

Castelar RM. O hospital no Brasil. In: Castelar RM, Mordelet P, Grabois V. Gestão Hospitalar: um desafio para o hospital brasileiro. França: Éditions ENSP; 1995.

Coopers e Lybrand. Remuneração por habilidades e por competências. Preparando a organização para a era das empresas de conhecimento intensivo. São Paulo: Atlas; 1997.

Cornetta VK. Recursos Humanos em Saúde: Reflexões e Desafios. In: Cianciarullo TI, Cornetta VK. Saúde, desenvolvimento e globalização: um desafio para os gestores do terceiro milênio. São Paulo: Ícone; 2002. 
Crawford, Richard. Na era do capital humano: o talento, a inteligência, e o conhecimento como forças econômicas, seu impacto nas empresas e nas decisões de investimento. Um guia que mostra como prosperar na economia. São Paulo: Atlas; 1994.

Dutra JS. O ambiente da liderança. Revista T\&D Inteligência Corporativa. 138.ed. São Paulo: T\&D; 2005. p.8-9.

Dutra JS. et al. Gestão por competências: um modelo avançado para o gerenciamento de pessoas. São Paulo: Editora Gente; 2001.

Dutra JS. Gestão por competências: um novo modelo de gestão de pessoas. In: 1. Encontro Internacional de Gestão de Competências em Qualidade de Vida no Trabalho; 1998; São Paulo, BR: FEA/USP. s/p.

Elliot, Andrew J. et al. Competence valuation as a strategic intrinsic motivation process. Personality and Social Psychology Bulletin. 2000; 26(7):780-794.

Fernandes BHR. Competências e performance organizacional: um estudo empírico [tese de doutorado]. São Paulo: Faculdade de Economia, Administração e Contabilidade da Universidade de São Paulo; 2004.

Ferreira, Aurélio Buarque de Holanda. Novo dicionário Aurélio da língua portuguesa. São Paulo: Nova Fronteira; 1975. p.354.

FPNQ-Fundação Prêmio Nacional da Qualidade. Rumo à excelência: critérios para avaliação do desempenho e diagnóstico organizacional. São Paulo; ciclo 2003-2004.

Gatti BA. Grupo focal na pesquisa em ciências sociais e humanas. Brasília: Líber Livro; 2005. 
Gerzon, Mark. Liderando pelo conflito: como líderes de sucesso transformam diferenças em oportunidades. Rio de Janeiro: Elsevier; 2006.

Gonçalves, Ernesto L., Aché, Carlos Augusto. O hospital-empresa: do planejamento à conquista do mercado. Revista de Administração de EmpresasFGV. 1999; 39(1):84-97.

Guerriero, I.C.Z. Aspectos éticos das pesquisas qualitativas em saúde [tese de doutorado]. São Paulo: Faculdade de Saúde Publica da Universidade de São Paulo, 2006.

Iervolino S A, Pelicioni M C F. A utilização do grupo focal como metodologia qualitativa na promoção da saúde. Revista Escola de Enfermagem USP. 2001; 34(2):115-121.

Leme, Rogério. Avaliação de desempenho com foco em competência: a base para remuneração por competência. Rio de Janeiro: Qualymark; 2006.

Marshall MN. Sampling for qualitative research. In: Teixeira JJV. A prescrição medicamentosa sob a ótica do paciente idoso: relação com os profissionais da saúde [dissertação de mestrado]. São Paulo: Faculdade de Saúde Pública da Universidade de São Paulo, 1998.

McDaniel C. e Roger G. Pesquisa de Marketing. São Paulo: Thomson Learning; 2006.

Minayo MCS. O desafio do conhecimento. Pesquisa qualitativa em saúde. 3. ed. São Paulo-Rio de Janeiro: Hucitec, Abrasco;1994.

Perazzolo E. As disciplinas da organização de aprendizagem integrando as competências gerenciais, nas instituições hospitalares [dissertação de mestrado]. São Paulo: Universidade Presbiteriana Mackenzie; 2000. 
Prahalad CK. A atividade dos gerentes da nova era no emergente panorama competitivo. In: Hesselbein, Francês, Goldsmith, Marshall, Beckhard, Richard. A organização do futuro: como preparar hoje as empresas de amanhã. São Paulo: Futura; 1997. cap. 16.

Prahalad, CK, Hamel, G. The core competence of the corporation. Harvard Business Review. 1990; 68(3):79-91.

Proetti S. Metodologia do trabalho científico. São Paulo: Edicon; 2005.

Rabaglio, Maria Odete. Ferramentas de avaliação de performance com foco em competências. Rio de Janeiro: Qualymark; 2006.

Rosso, F. Gestão ou indigestão de pessoas: manual de sobrevivência para RH na área da saúde. São Paulo: Loyola; 2003.

Rost, J.C. Leadership for the twenty-first century. In: Yukl, Gary A. Leadership in organizations. 5.ed. New Jersey: Prentice Hall; 2001.

Tachizawa, T.; Scaico, O. Organização flexível: qualidade na gestão por processos. São Paulo: Atlas; 1997.

Tachizawa T, Junior JBC, Rocha JAO. Gestão de negócios: visões e dimensões empresariais da organização. 3.ed. São Paulo: Atlas, 2006.

Teixeira JJV. A prescrição medicamentosa sob a ótica do paciente idoso: relação com os profissionais da saúde [dissertação de mestrado]. São Paulo: Faculdade de Saúde Pública da Universidade de São Paulo, 1998. 
Vansteenkiste, Maarten et al. Intrinsic versus extrinsic goal contents in selfdetermination theory: another look at the quality of academic motivation. Educational Psychologist, Lawrence Erlbaum Associates, Inc. 2006; 41(1):19-31.

Wardman, Kellie T. Criando organizações que aprendem. São Paulo: Futura; 1996.

Yukl, Gary A. Leadership in organizations. 5.ed. New Jersey: Prentice Hall; 2001.

Xavier, Ricardo de Almeida Prado. Competência para o sucesso: como prepararse para uma carreira executiva sólida. São Paulo: Editora STS; 2002. 


\section{BIBLIOGRAFIA CONSULTADA}

Dressler et al. Core competencies in hospital medicine: development and methodology. Journal of Hospital Medicine. 2006; 1(1):48-56.

Hesselbein F, Goldsmith M, Beckhard R, editores. The Peter F. Drucker Foundation, organização. O líder do futuro: visões, estratégias e práticas para uma nova era. Trad. de Cynthia Azevedo. 6.ed. São Paulo: Futura; 1996.

Kanaana, Roberto. Comportamento humano nas organizações: o homem rumo ao século XXI. São Paulo: Atlas; 1995.

Longenecker, Paul D. Evaluating transformational leadership skills of hospice executives. American Journal of Hospice and Palliative Medicine. 2006; 23(3):205-211.

Morgan, Gareth. Imagens da organização. 2.ed. São Paulo: Atlas; 2002.

Pistono, Marcos Heitor. Dimensões da qualidade e gestão da qualidade total em organizações médico-hospitalares: um guia prático para implantação da qualidade total em serviços médico-hospitalares. Corbã Editora Artes Gráficas Ltda; 1995.

Semenik, Richard J. Princípios de marketing: uma perspectiva global. São Paulo: Makron Books; 1995.

Taylor, Vicki. Leadership for service improvement: part 2. Nursing Management. 2007; 13(10):32-35.

Tracy, Diane. 10 passos para o empowerment: um guia sensato para a gestão de pessoas. Rio de Janeiro: Campus; 1994.

Universidade de São Paulo. Faculdade de Saúde Pública. Guia de apresentação de teses. São Paulo; 2006. 


\section{A NEXOS}

\section{Anexo 1}

\section{Carta de convocação dos líderes}

São Paulo,__ de_ de 200_

Prezado(a) Sr(a)

Os hospitais têm buscado, com freqüência, duas condições importantes em sua realidade: a qualidade do serviço prestado e o alcance de resultados que agregam valor às diretrizes da organização.

Essas ações acontecem por meio dos líderes que, no exercício de suas competências, são colocados diante de situações desafiadoras ao gerenciar os processos de trabalho, procurando envolver as pessoas da equipe, assim como criar um ambiente de trabalho propício à participação e à aprendizagem.

As competências devem ser continuamente desenvolvidas e avaliadas de forma sistemática. O processo de avaliação de desempenho é carente na área da saúde em virtude de sua complexidade, pois, lida com questões subjetivas e objetivas da relação líder - liderado.

Por esse motivo, é fundamental conhecer o processo de avaliação de desempenho a partir das opiniões e sentimentos dos lideres sobre o assunto. Tal desafio inspirou meu trabalho de doutorado.

Desta forma, gostaria de convidá-lo (a) a participar da dinâmica de grupo sobre avaliação de desempenho, na data e horário descritos abaixo, onde as pessoas estarão expondo suas opiniões sobre o assunto.

\section{Data:}

Horário:

Local: Sala de Treinamento, $2^{\circ}$ andar, bloco I

Suas informações serão fundamentais para meu trabalho. Agradeço, antecipadamente, sua colaboração.

Elizabeth Perazzolo 


\section{Anexo 2}

\section{Guia de discussão para grupos de líderes sobre a avaliação de desempenho}

\section{Ambiente preparado para receber o grupo e iniciar as atividades.}

\section{Explicar sobre o que são Grupos de Foco e suas regras (10’)}

a) Não há respostas certas; somente opiniões. O grupo está falando em nome de muitas outras pessoas.

b) Precisamos ouvir todos.

c) Uma colega está nos observando no fundo da sala. Ela está muito interessada na opinião de todos.

d) Gravação - não precisando tomar nota, posso estar concentrada no que cada um tem a dizer.

e) Somente uma pessoa fala de cada vez. Por favor, não façam discussões paralelas, pois posso perder algum comentário importante.

f) Peço para não me fazerem perguntas: o que eu sei e o que eu penso não é importante. O importante é o que vocês (grupo) pensam e o que vocês acham.

g) Não se sintam mal se não conhecem muito bem algumas das coisas das quais estaremos falando. Se o seu ponto de vista for diferente dos demais, é muito importante para os trabalhos.

h) Abordaremos uma série de tópicos. Estarei redirecionando a discussão.

i) Alguma pergunta antes de começar?

\section{Conhecendo as atitudes do grupo sobre o assunto Avaliação do Desempenho no Trabalho.}

a) O que vocês esperam de uma avaliação? (mapear expectativas)

b) Como foi a avaliação de vocês? Como vocês se sentiram durante o processo? (mapear a realidade e os sentimentos presentes)

c) Do que vocês gostaram e não gostaram quando foram avaliados?

d) O que vocês acham mais importante avaliar?

e) Quando vocês precisam avaliar alguém, como vocês fazem? E o que os motiva?

f) Quais são os atributos mais significativos a serem avaliados em um líder?

g) Suponhamos que não houvesse nenhum formulário de avaliação e vocês tivessem que criar um. Quais informações vocês colocariam? E, como apresentariam os resultados finais da avaliação? 


\section{Anexo 3}

\section{Caracterização do sujeito da pesquisa}

. Data de nascimento:

2. Sexo:

2.1. ( ) masculino

2.2. ( ) feminino

3. Profissão:

4. Data de admissão no hospital:

5. Nome do cargo que ocupa (hoje):

6. Tempo no cargo atual:

7. Jornada de trabalho:

8. $\mathrm{N}^{\mathrm{o}}$. de funcionários que estão sob sua responsabilidade: 


\section{Anexo 4}

Termo de consentimento das lideranças entrevistadas

\section{TERMO DE CONSENTIMENTO LIVRE ESCLARECIDO PARA PARTICIPAÇÃO EM TRABALHO CIENTÍFICO}

Projeto de pesquisa: Análise de avaliação de desempenho em hospital público.

O objetivo da presente pesquisa é conhecer, segundo a ótica das lideranças de hospital público, o processo de avaliação de desempenho revelando aspectos fundamentais para sua eficiência.

Solicito seu consentimento para participar da dinâmica de grupo, onde as pessoas estarão falando sobre avaliação de desempenho.

Tendo sido satisfatoriamente informado (a) sobre a pesquisa "Análise de avaliação de desempenho em hospital público” sob a responsabilidade de Elizabeth Perazzolo, com a orientação da Professora Dra Vitória Kedy Cornetta da Faculdade de Saúde Pública da Universidade de São Paulo, declaro que concordo em participar da mesma, contribuindo com a dinâmica de grupo.

Estou ciente de que as informações serão utilizadas exclusivamente pela pesquisadora, preservando-se o sigilo; que a mesma está disponível para responder a quaisquer perguntas e que poderei retirar este consentimento a qualquer tempo.

São Paulo, de de $200 \ldots$ 